\title{
Conjugate Margins Conference 2018
}

\section{Celebrating 10 years of the CMC: pushing the boundaries of knowledge}

\author{
August 19 - 22, 2018
}

Dalhousie University, Halifax, Nova Scotia, Canada

Halifax 2018 continued the tradition of bringing together academic, government, and industry geoscientists to discuss the evolution of the Atlantic conjugate margin basins and explore the latest concepts and interpretations of their petroleum systems. This was the sixth biennial international conference with the inaugural meeting held in Halifax in 2008, followed by successful gatherings in Lisbon (2010), Dublin (2012), St. John’s (2014), and Recife (2017).

On behalf of the Conference Committee, we sincerely thank Natasha Morrison and Trudy Lewis for their outstanding organizational expertise, as well the numerous student volunteers and judges, for all their assistance with the organization and logistic of such large meeting. The meeting had the financial support of the Nova Scotia Department of Energy, the Offshore Energy Research Organization, Equinor, and Husky Energy (Diamond sponsors), CGG (Platinum sponsor), GEOExPro, BeicipFranlab, Atlantic Geoscience Society, American Association of Petroleum Geologists Canada Region, BP, and Earthmoves (Gold sponsors), ExxonMobil, Dalhousie University and the Basin and Reservoir Lab (Bronze sponsors), RPS Group, Merit Travel, Agile Scientific, International Association of Sedimentologists, Lynx Information Systems, the University of Manchester University and the North Africa Research Group, Natural Resources Canada - Geological Survey of Canada, and the Canada-Nova Scotia Offshore Petroleum Board (Patrons and Supporters).

In the following pages, we are pleased to publish the abstracts of oral and poster presentations from the meeting. The conference sessions ran over three days and included Geodynamics, Stratigraphy and Sedimentology, Regional Geology, Geochemistry and Petroleum Systems, with Exploration Thinking for the Atlantic Conjugate Margins on the final day. There were poster presentations, two field trips, two salt-related short courses, a conventional core workshop, display of recent Atlantic region seismic programs, industry displays, and social events including a student breakfast sponsored by the AAPG Canadian Region. We sincerely thank Dr. Sandra Barr and Dr. Chris White for their editorial assistance in publishing this abstract volume in Atlantic Geology.

In keeping with our theme - "Pushing the Boundaries of Knowledge" - on Monday, August 20, Professor John F. Dewey gave the plenary conference address followed by the awarding of his honorary degree by Dr. Richard Florizone, President of Dalhousie University. Professor Dewey's scientific leadership has provided a clearer understanding of the tectonic evolution of sedimentary basins along the Atlantic margins.

The large attendance was a confirmation that many believe the basins of the Atlantic realm have excellent potential for new discoveries and will provide new insights on crustal rifting and the early development of passive margins and their petroleum systems. Thank you to all of those who travelled to Halifax to share your ideas and we hope your stay in Nova Scotia was productive and enjoyable. On behalf of the Conference Committee members and all our sponsors, thank you!

DAVID E. BROWN, GRANT D. WACH, RICARDO F. L. SILVA, AND PAUL J. POST CONFERENCE COMMITTEE 
Testing sequence stratigraphic models through highresolution 3D seismic imaging of Miocene foresets on the New Jersey shallow shelf, USA

\section{Masoud Aali ${ }^{1}$, Mladen Nedimovic ${ }^{1}$, Gregory Mountain $^{2}$, Graig S. Fulthorpe ${ }^{3}$, James Austin ${ }^{3}$, Bill RICHARDS $^{1}$, AND NEIL WATSON ${ }^{1}$}

\section{Department of Earth Sciences, Dalhousie University, Halifax, Nova Scotia B3H 4J1, Canada g \\ 2. Department of Earth and Planetary Sciences, Rutgers University, Piscataway, New Jersey 08854, USA g \\ 3. Jackson School of Geosciences, University of Texas at Austin, Austin, Texas 78712, USA}

The New Jersey margin is considered a classic example of a rifted margin. Because of its stable tectonic history, smooth thermal subsidence, and consistent deltaic sediment loading since Miocene, it has become a pre-eminent area for investigating the effects of global sea-level change and very well studied for that purpose since 1988. This was done most intensively by IODP Expedition 313 in April-July 2009, where three boreholes continuously cored much of the Miocene section, collecting extensive data from multiple clinoform topsets, foresets, and toesets previously imaged on a $140 \mathrm{~km}$ shelf-to-slope 2D seismic line. Subsequent to Expedition 313 , a high-resolution P-Cable 3D seismic survey $(11 \times 50$ $\mathrm{km}$ ) was acquired in 2015 (Research Cruise MGL1510).

In this paper, we present preliminary results from this $3 \mathrm{D}$ survey by integrating three interpretation approaches in a 3D geocellular model: quantitative geophysics (P-wave velocity, density, clay volume); attribute analysis (surface, interval and volume attributes); and seismic stratigraphy (depositional sequences interpreted using objective geometric criteria). The estimated clay volume consistently shows an inferred coarsening-upward signature in each progradational sequence. Attribute displays derived from reflection amplitude are hampered by small time shifts in the cross-line (margin parallel) direction at the edges of each sail line. These shifts may be related to uncertainty in streamer positioning. Nevertheless, the reflection amplitude attribute displays are effective in rendering polygonal fault systems formed in stressed hemipelagic sediments within the toes of clinoforms.

Approximately sixty surfaces and depositional units have been recognized and interpreted by loop-tying within the 3D seismic volume, enhancing the framework previously published using 2D data. Depositional units are characterized by bounding reflections and stratal terminations, and the relative position of forestepping, upstepping, backstepping, and downstepping parasequences enable the interpretation of systems tracts. The data set is currently being reprocessed with the goal of ameliorating the time shift problem.

\section{From the equatorial Atlantic to the Laptev Sea: the role of tectonic inheritance in the continental breakup and evolution of the Atlantic and Arctic oceans}

BRIDGET E. ADY

\section{GeoArctic Ltd., Calgary, Alberta T2P 2V7, Canada}

In the more than fifty years since J. Tuzo Wilson posed the question, 'Did the Atlantic close and then reopen?', we have come to understand that the continents preserve the tectonic record of multiple superimposed Wilson cycles. From the Central Atlantic to the Arctic, structural lineaments from Proterozoic and Paleozoic orogenies record the closing of earlier oceans. What influence did these inherited orogenic structures exert on the tectonic evolution of the present day North Atlantic and Arctic margins? By quantitatively restoring Mesozoic-Cenozoic extension of up to several hundred $\mathrm{km}$ on some hyperextended parts of the Atlantic and Arctic margins, we show that a palinspastic deformable margin plate kinematic model is a valuable analytical tool when applied to the evaluation of the role of pre-existing structures in continental breakup. THis includes examination of the evolution and orientation of rifting events, the reactivation of sutures and thrust fronts, the interplay between sutures of various ages, and the activation of major transforms from pre-existing sutures. Prerift restoration of the Proterozoic and Paleozoic terranes and structural lineaments on the conjugate margins aids in the analysis of their relationship to evolving rift axes and global plate reorganization events.

The present-day Guyana-Suriname to Senegal-Mauritania conjugate margins are separated from the Laptev Shelf in the eastern Arctic by the ca. $10000 \mathrm{~km}$ north-south expanse of the Central and North Atlantic oceans and the Eurasia Basin of the Arctic Ocean. Continental breakup started in the Jurassic with the opening of the Central Atlantic and by the Eocene had propagated northwards to the Eurasia Basin. Our palinspastic deformable margin plate reconstruction of the region restores the history of the crustal deformation and multiple rifting episodes, with retro-deformed beta and crustal thickness maps charting the evolution of the rifted and hyperextended basins of the Atlantic and Arctic. Advances in deformable plate reconstruction methods provide us with accurately restored pre-breakup margin geometry, more detailed restored and reconstructed basement and structure maps, and the history of lateral strain and crustal thinning across these margins. Interpretation of these modelling results has led to a clearer understanding of the relationship between inherited structural features and their control on rifting, breakup history, and basin development. 


\section{Early Mesozoic detrital and evaporitic synrift series of the Mohammedia-Benslimane-ElGara-Berrechid basin (western Meseta, Morocco): sedimentary and palaeoenvironmental evolution and comparison with the basins of the northeastern American Margin}

\section{Abdelkrim Afenzar and Rachid Essamoud}

Dynamics of Sedimentary Basins and Geological Correlations

Laboratory, Faculty of Sciences, Ben M'Sik Hassan II University of Casablanca. Casablanca, Morocco

In the early Mesozoic, the northwestern part of the African continent was affected by initial breakup associated with the early stages of opening of the Central Atlantic (Central Atlantic rifting). During this phase the Moroccan Meseta was subjected to an extensional tectonic regime. This extension has led to the opening of a set of rift basins including the Mohammedia-Benslimane-ElGaraBerrechid basin (MBEB), the focus of this study.

Sedimentological analysis, which is the objective of our work, has shown that during the synrift phase (Upper Triassic-Lower Jurassic) the MBEB basin is characterized by detrital and evaporite sediment filing. This study made it possible to characterize fifteen types of facies and eight architectural elements and facies associations. A gradual decrease of palaeoslope over time led to the evolution of paleoenvironments during this filling from a proximal alluvial fan system to braided rivers, and then to an anastomosing system. These environments eventually evolve to an alluvial plain associated with a coastal plain where playa lakes, mudflats, and lagoons developed. The pure and massive halitic facies at the top of the series probably indicates evolution of the depositional setting towards a shallow to deep subtidal environment. The presence of evaporites indicates a hot and arid climate that favored their precipitation.

This work allowed a comparison of the sedimentary series of this basin with those of the northeastern North American margin. With respect to sediment-filling history, the southern and central parts of the North American basins resemble the Moroccan Atlasic basins as well as the basal detrital formations of the Mesetian and Moroccan Atlantic margin basins. These basins are characterized by continental sedimentation during the Upper Triassic (fluvial deposits interbedded with lacustrine and playa deposits). The North American basins also have similarity with our study basin and other basins of the Moroccan Atlantic margin in the presence of evaporites.

\section{A stratigraphic record of enhanced subsidence during continental breakup: do breakup sequences rule over unconformities?}

Tiago M. Alves ${ }^{1}$ and Tiago A. Cunha ${ }^{2}$

\section{3D Seismic Lab - School of Earth and Ocean Sciences, Cardiff University, Cardiff, Wales CF10 3AT, United Kingdom 9 \\ 2. Integrated Geochemical Interpretation Ltd., Bideford, Devon EX39 5HE, United Kingdom}

Late Jurassic-Cretaceous rifting and continental breakup of the North Atlantic Ocean was complex, and present-day paleogeographic reconstructions have yet to address the position of micro-plates such as Iberia. As an alternative method to predict source and reservoir potential in North Atlantic rift basins, the focus has changed in recent years towards understanding the topography of paleo-rift axes, continental slopes, marginal highs, and shelves, using seismic and stratigraphic data from multiple sources. In such a setting, West Iberia differs from the North Sea, proximal Newfoundland basins, and Ireland, by presenting excess accommodation space for sediment sourced from hinterland areas. Such a character was accompanied by important bypass of sediment towards the North Atlantic rift axis, with excess accommodation space resulting in enhanced conditions for the generation of 'black shales' in these regions. This presentation uses seismic profiles, borehole data, and tectonic-subsidence models to stress the following three characteristics: (1) the important $\mathrm{mi}$ gration of slope facies towards the west and southwest recorded in West Iberia during Late Jurassic-Early Cretaceous; (2) the predominance of a slope-fed depositional system through the latter stages of rifting and continental breakup; and (3) the near-permanence of topographically sheltered, 'sediment starved' conditions in the future region of continental breakup during the Late Jurassic and Early Cretaceous.

The maintenance of these characteristics until continental breakup was achieved in the whole of the Iberian plate, from which point slope progradation ceased, subsidence increased dramatically in offshore basins, and bypass of sediment predominated on the continental slope. Such a character indicates a Cenomanian/early Turonian age for the end of the synrift process along the whole of the Iberian Plate into the Bay of Biscay, with discrete breakup sequences marking diachronous continental breakup events on successive segments of the margin. Field areas demonstrate sediment bypass during diachronous continental breakup along West Iberia. Most published literature misrepresents the importance of such forced-regressive events on the 'outer proximal margin' of West Iberia. We also compare stratigraphic successions at outcrop with borehole and seismic data, extending our analysis from the shallow offshore to more 'distal' basins. 


\section{Reconstructing the Carboniferous paleogeography of the northeast Atlantic margin using provenance tools}

\section{Bébhinn Anders ${ }^{1,2}$, Martin Nauton-Fourteu ${ }^{1,2,3}$, Shane TyrreLL ${ }^{1,2,3}$, John MURRAY ${ }^{1,3}$, AND JohN R. GrahaM ${ }^{4}$ \\ 1. Earth and Ocean Sciences, School of Natural Sciences, National University of Ireland Galway, Galway, Ireland 9 \\ 2. Sediment Origins Research Team (SORT), School of Natural \\ Sciences, National University of Ireland Galway, Galway, Ireland \\ 3. Irish Centre for Research in Applied Geosciences (iCRAG), \\ O'Brien Centre for Science (East), University College \\ Dublin, Belfield, Dublin 4, Ireland 9 \\ 4. Department of Geology, Trinity College Dublin, \\ Dublin 2, Ireland}

Reconstruction of Upper Paleozoic paleogeography of the Northeast Atlantic region can help to constrain possible prerift links between the conjugate margins. The broader region comprises a geologically complex assemblage of blocks and belts that have been affected by multiple orogenies since the Paleoproterozoic. Provenance analysis can help to identify these events, as the sedimentary rock archive preserves a detrital record reflecting the nature and composition of these ancient landscapes. Carboniferous sedimentary rocks in basins onshore Ireland and Britain form an important part of this archive, representing large- to medium-scale rivers and associated deltaic systems deposits. They potentially drained and sampled a wide portion of the NE Atlantic region and consequently provide a means to better constrain potential source lands.

To investigate these concepts, this study targeted the Mullaghmore Sandstone Formation (MSF), which occurs in the North West Carboniferous Basin (NWCB; onshore northwest Ireland). The MSF is a Mississippian fluvial/deltaic deposit, generally interpreted as the product of regional lowstand. Provenance analysis was conducted through high-resolution sampling and a multi-proxy approach, using optical microscopy, scanning electron microscopy, $\mathrm{U}-\mathrm{Pb}$ zircon and $\mathrm{Pb}$-in-K-feldspar analysis. Recovered grains show a range of detrital ages, corresponding to several regional orogenic events. Preliminary results indicate paleoflow from the north/northwest, with mixed sediment supply from sources including Greenland, northwest Scotland, offshore Ireland highs, and with minor input from Caledonian rocks. It is now apparent that the Rockall Bank, Porcupine High, and Stanton Banks were significant sources of the sediment supplied to the NWCB.
This study has also revealed important information on contemporaneous sedimentary processes, such as longshore drift and shelf mixing, which can directly affect the source signal. The MSF is ideally placed to test this: cycles of various facies packages are clearly evident and spatial variations in the provenance signal can be investigated from exposed sections in different parts of the basin. Zircon geochronological data show that channelized sediments have a more unimodal signal in comparison to shoreface facies, which have a mixed signal. This illustrates the importance of understanding the sedimentological context of any sample being investigated using provenance tools.

Diagenetic effects at erosional boundaries in the Triassic Wolfville Formation at Rainy Cove, Nova Scotia, Canada

\section{Erin D. Anderson, Jennifer Lee, and Grant Wach}

Basin and Reservoir Lab, Department of Earth Sciences, Dalhousie University, Life Sciences Centre, Halifax, Nova Scotia B3H 4R2, Canada

At Rainy Cove (Minas Basin, Nova Scotia), lithological heterogeneity in the sedimentary successions of the Upper Triassic Wolfville Formation is expressed by preferential erosion and preservation of the coastline. This study hypothesized that the observed variations in erosion style at Rainy Cove were a result of differences in cementation texture between siliciclastic lithofacies.

To test this hypothesis, we investigated the lithologic characteristics and cement textures in a series of vertically stacked alluvial and fluvial successions from the Wolfville Formation. Lithologic heterogeneities affect permeability in the sedimentary successions and impact fluid flow and reservoir quality within the formation. Six lithofacies were identified at the study location: (F1) matrix-supported clastic breccia from alluvial debris flows, (F2) clast- to matrixsupported conglomerate, (F3) pebbly to clean sandstone, (F4) silty sandstone, (F5) clay, and (F6) paleosol.

All lithofacies are cemented by carbonate with blocky, granular, and dogtooth textures exhibiting dull cathodoluminescence. Cements are interpreted to have precipitated in a burial diagenetic environment. All samples have the same overall cement characteristics, and the observed textures are not limited to any single lithofacies. This suggests that cementation style is not the main control on the differential preservation of outcrop sections. Samples have generally low permeability with a range of 32.78 to $276.53 \mathrm{mD}$. Pervasive cementation contributes to poor reservoir quality in the Wolfville Formation at Rainy Cove. 
High resolution regional earth systems modelling in the predictive mapping of reservoir and source rock environments in the Late Permian North Atlantic

\section{Alexandra J. Ashley ${ }^{1}$, Jim P. Harris ${ }^{1}$, Simon C. Otto ${ }^{1}$ John Watson ${ }^{1}$, Simone Agostini ${ }^{1}$, Mike Goodrich ${ }^{1}$, Paul J. Valdes ${ }^{2}$, And Alexandros Avdis ${ }^{3}$ \\ 1. CGG Services UK, Tyn-y-Coed, Llandudno LL30 ISA, United Kingdom $\mathbf{g}$ \\ 2. School of Geographic Sciences, University of Bristol, Clifton, Bristol BS8 1SS, United Kingdom 9 \\ 3. Imperial College London, South Kensington Campus, London SW7 2AZ, United Kingdom}

Although hydrocarbon generation has been heavily studied in conventional petroleum-forming basins, the primary mechanisms responsible for converting the initial inputs of sedimentary organic matter into petroleumforming hydrocarbons is still not fully understood. Intact polar lipids (IPLs) are a fundamental component of sedimentary organic matter. IPLs are composed of a core lipid chemically bonded to a polar head group. These lipids are constituents of cellular membranes. Consequently, IPLs are biomarkers for living and/or very recently deceased organisms due to their labile headgroup, which gets hydrolyzed quickly after cell death. IPLs can also be taxonomically distinct and useful for reconstruction of organic matter source inputs. The polar headgroups of IPLs quickly degrade after the death of a cell and the remaining core lipid may become biodegraded. However, a portion of the altered products will likely become bound to kerogen or assimilated as inherited bitumen where it may later crack to release petroleum. This break down and assimilation may occur at depth over tens to thousands of years depending on the geochemical and sedimentological conditions of the depositional environment. However, this process occurs naturally and at an accelerated rate in very shallow buried sediments within organic-rich, sedimented hydrothermal vent systems. This study will identify and quantify the IPLs recovered from a push core transect running from the interior to exterior of the Cathedral Hill hydrothermal vent site in the Guaymas Basin, Gulf of California. IPLs will be extracted from sediments using a modified Bligh \& Dryer protocol and analyzed with an UHPLC-qToF-MS to identify the diversity and quantity of living and recently deceased organisms in relation to their exposure to high temperature vent fluids (up to $142^{\circ} \mathrm{C}$ ). This study will explore whether the IPLs can (1) provide insight into thermal-chemical limits in which IPL structures can be preserved and (2) enable the precise sequence of reactions to be monitored that results in their conversion into hydrocarbons. This study will also document the reaction pathways leading to the conversion of these lipids into petroleum forming hydrocarbons, which may be used as a proxy for the reaction mechanism that likely occur in conventional petroleum forming basins.

\section{Chemostratigraphy and sedimentary provenance analysis for the Jeanne d'Arc and Flemish Pass basins, Grand Banks, Canada}

\section{Marta Barbarano, John Martin, David A. Riley, AND Tim J. Pearce \\ Chemostrat Ltd., Buttington Cross Enterprise Park, Welshpool, Montgomeryshire SY21 8SL, United Kingdom}

The Jurassic-Cretaceous succession of the Flemish Pass, Jeanne d'Arc, and other nearby basins is the focus of this study. The Grand Banks area is associated with the opening of the North Atlantic Ocean, with paleogeographic reconstructions placing it close to the conjugate Irish Porcupine and Rockall basins, and to the landmasses of Greenland and Iberia. Possible sedimentary sources are these landmasses, the Avalon terrane and the Flemish Cap. We coupled Raman heavy mineral (HM) analysis and zircon $\mathrm{U}-\mathrm{Pb}$ geochronology, with the aim of helping in modelling ground-truth sediment provenance and gross depositional environment maps for the Grand Banks.

The HM were concentrated and identified via Raman spectroscopy; zircon ages were determined via laser ablation - inductively-coupled plasma - mass spectrometry analysis performed on more than 150 samples for a total of 18 wells. We performed elemental analysis via ICP-MS and stable isotope $\left(\delta^{13} \mathrm{C}_{\text {carb }}\right.$ and $\left.\delta^{18} \mathrm{O}_{\text {carb }}\right)$ analysis, to build a chemostratigraphic correlation.

From our multidisciplinary dataset, it is possible to recognize provenance changes occurring both stratigraphically and geographically, and our provenancerelated data support our chemostratigraphic correlation. For example, in Jurassic and Cretaceous sediments of Harpoon O-85 well (Flemish Pass Basin), Neoproterozoic zircon ages are predominant, followed by Paleoproterozoic and Paleozoic ages. In Terra Nova I-97 (Jeanne d'Arc Basin), Jurassic sediment has Neoproterozoic (most abundant), Paleozoic, Mesoproterozoic, and Paleoproterozoic zircon ages, whereas Cretaceous sediment has Neoproterozoic and Paleozoic grains. From these data, we interpret a different provenance between the Flemish Pass and the Jeanne d'Arc basins and, in the latter, a change at the Jurassic-Cretaceous boundary. Heavy mineral and zircon ages that suggest provenance from the Flemish Cap were observed in the Cretaceous sediments of Harpoon O-85.

On the basis of elemental (variations in $\mathrm{Si}, \mathrm{Zr}, \mathrm{Ti}, \mathrm{Nb}, \mathrm{Ta}$, $\mathrm{Rb}, \mathrm{U}, \mathrm{Th}, \mathrm{Ga}, \mathrm{V}$ and REEs associated with changes in quartz, feldspar, heavy minerals, clays, and organics), isotopic, and zircon geochronological data, Hibernia equivalent sandstones penetrated by the St. George J-55 well (Carson Basin) have been divided into three packages. Two of these three can be correlated with two packages occurring in the Hibernia sandstones penetrated by Terra Nova I-97 (Jeanne d'Arc): the deepest one of J-55 has not been deposited or has been eroded away from the succession penetrated by I-97. 


\section{Portugal: a biostratigraphic and seismically integrated approach to understanding the North Atlantic conjugate margins} Ana Bento, Sean Pyman, Jim Fenton, Alex Fowler,
And James (Jim) P. Harris

CGG Robertson, Tynycoed, Llanrhos, Llandudno, Wales LL30 1SA, United Kingdom

Exploration success in the North Atlantic Conjugate Margins (NACM) is far from symmetrical with a distinct bias towards Newfoundland's Jeanne d'Arc and Flemish Pass basins. Recent discoveries in the latter have re-ignited interest in the wider region, particularly the conjugate basins offshore Ireland and Portugal. Fundamental to exploration is a unified stratigraphic framework, though this poses a significant challenge due to the paucity of data, inconsistent vintage data sets, and rock availability, especially in such a complex rift-drift evolutionary setting. To address these uncertainties, a comprehensive mega regional dataset was assembled and a multi-disciplinary petroleum geological evaluation was undertaken aside with new Portuguese biostratigraphic study of five wells.

Wells were selected from the Porto (Lula-1 and 5A-1) and Lusitanian (14C-1A, 16A-1 and 20B-1 wells) basins based on their intersection with seismic lines, availability of cuttings samples, existing biostratigraphic data, and depth of penetration. Available samples from these wells were studied for micropalaeontological, nannopalaeontological, and palynological information together with the review and reinterpretation of available biostratigraphic reports. A series of new bioevents were identified within these five Portuguese wells through the integration of all available vintage biodata, new analyses, wireline log data, and other pertinent geological inputs with a detailed biostratigraphic study - the first of its kind to date. These robust bioevents allow identification and a better understanding of the regional unconformities and their correlation across the NACM plus their extent. This contribution summarizes how an integrated approach, honouring a diverse suite of data, provides unique insight into the rifting history of the North Atlantic region with the potential of direct implications for exploration in the NACM.

Sedimentary architecture and Cenozoic magmatic evolution of the Hatton Basin, offshore Ireland, from seismic and potential field data

Laura Bérdi ${ }^{1,2,3}$, Manel PradA ${ }^{1,2}$, Brian O’Reilly ${ }^{1,2}$, Patrick Shannon ${ }^{2,3}$, Peter Haughton ${ }^{2,3}$, and Sara MARTÍNEZ-LORIENTE ${ }^{2,3}$

\author{
1. Dublin Institute for Advanced Studies (DIAS), \\ Geophysics Section, Dublin 2, Ireland $\mathbf{g}$ \\ 2. Irish Centre for Research in Applied Geosciences \\ (iCRAG), O'Brien Centre for Science (East), University College \\ Dublin, Belfield, Dublin 4, Ireland g \\ 3. School of Earth Sciences, University College Dublin, \\ Belfield, Dublin 4, Ireland
}

The Hatton Basin is located at the western European Atlantic Margin, approximately $600 \mathrm{~km}$ west of Scotland and Ireland, and bounded by the Rockall Bank to the east and the Hatton High to the west. Little is known about its structure and evolution within the context of the North Atlantic opening. Here, we present a preliminary interpretation of the large-scale sedimentary structure and Cenozoic magmatic evolution of the Hatton Basin from new 2D regional long-streamer seismic reflection data, DSDP information, and potential field data (i.e. magnetic and gravity data).

First interpretations of the seismic data suggest the presence of three sedimentary megasequences referred to as $\mathrm{Ha}$ (Early Pliocene to Holocene), $\mathrm{Hb}$ (Late Eocene to Late Miocene) and Hc (Paleocene to middle Eocene), which are bounded by regional unconformities C10 (intra-Early Pliocene), C30 (intra-Late Eocene) and C40 (base Cenozoic) respectively. Furthermore, an angular unconformity possibly of latest Early-Middle Eocene in age is present locally in the basin which corresponds to a post-rift volcanic phase. Some of the volcanoes formed during this period were active until the deposition of the intra-Late Eocene (C30) unconformity.

The presence of Mesozoic and/or older rocks in the basin is proposed based on the seismic character of the reflectors and the apparent rotated fault blocks. The lower Cenozoic succession contains Eocene prograding sedimentary wedges as well as intrusive and extrusive igneous rocks of basaltic composition (Late Paleocene-Early Eocene and EarlyMiddle Eocene? in age). The upper Cenozoic sediments are characterized by the deposition of contourites and mass transport deposits.

Both magnetic and gravity data show similar NE-SW trending lineaments of anomalies extending from the center of the basin towards the southern end. The location of the mapped volcanic craters in the basin is coincident with these anomalies. The connection between the craters and the magnetic and gravity anomalies potentially reflect areas with stronger magmatic influence. The absence of these anomalies in the northern part of the basin implies that magmatic activity during basin evolution might have been stronger and more pronounced on the southern part of the area and was weaker towards the north. 


\section{Structural style and fault evolution in the greater Bay du Nord area, Flemish Pass Basin, offshore Newfoundland, Canada}

\section{Asdrúbal J. Bernal ${ }^{1}$, Rainer Tonn ${ }^{1}$, Enrique NovoA ${ }^{2}$, AND Bo SøDERSTRøM ${ }^{3}$ \\ 1. Equinor Canada Ltd., St. John's, Newfoundland and Labrador A1C 6J5, Canada g \\ 2. Equinor Gulf Services LLC, Houston, Texas 77042, USA g \\ 3. Equinor ASA, Martin Linges vei 33, Fornebu 1330, Norway}

The structural style, timing of deformation, and interaction of fault sets in the Greater Bay du Nord Area, Flemish Pass Basin, have been interpreted using seismic and borehole data. The structural style in the study area is dominated by rollover anticlines with erosion in the up-dip, crestal areas. These rollovers are related to complex interactions of low angle listric and associated synthetic and antithetic faults; some of them displaying conjugate geometry. We interpret three Mesozoic fault populations: (1) relatively long, NESW-striking faults with dominant vergence to the east and high displacement and height that extend into pre-Jurassic strata; (2) NW-SE-striking faults, with no clear dominant vergence and confined within the Jurassic-Cretaceous succession, has much less displacement and length; and (3) faults with NNE-SSW to NNW-SSE strike and variable displacement, lateral extent, and height. A major normal fault striking E-W bounds the Greater Bay du Nord Area to the south.

Integration of structural and isopach maps, growth strata analysis, and evaluation of fault interactions allows us to propose a timing of fault activity and relate it to the rotation of extension direction throughout the Mesozoic. We suggest three pulses of tectonic activity. The first pulse relates to a rift climax phase of Oxfordian-Kimmeridgian in the Flemish Pass, with the major E-W-striking and NE-SWstriking fault population accommodating this deformation. A period of relative tectonic quiescence is observed in the Upper Tithonian, where differential subsidence and minor faulting is interpreted. The second pulse develops in the Early Cretaceous with most of the fault growth and propagation occurring during the Berriasian to Hauterivian(?) with a NNE-SSW to NNW-SSE orientation and dominant vergence to the east. These developed west-dipping rollover anticlines and associated west-verging half-graben depocentres. The NW-SE-oriented fault population develops during the Aptian-Albian. The E-W-striking bounding fault and the NNE-SSW fault sets re-activate during this time, with different degrees of strike-slip displacement expected during fault reactivation in Early Cretaceous time. The third phase of tectonic deformation comprises mild inversion in the transition of Early to Late Cretaceous, followed by westward subsidence of the basin during Tertiary and the development of polygonal faulting.
Late Jurassic-Early Cretaceous sand supply in the Scotian Basin, Canada: insights from $\mathrm{Pb}$ isotopic fingerprints

Aoife Blowick ${ }^{1}$, Georgia Pe-Piper², David J.W. PiPer ${ }^{3}$, and Shane Tyrrell ${ }^{1}$

1. Sediment Origins Research Team, Earth and Ocean Sciences and Irish Centre for Research in Applied Geosciences (iCRAG), National University of Ireland, University Road, Galway, Ireland 9

2. Department of Geology, Saint Mary's University, Halifax, Nova Scotia B3H 3C3, Canada g

3. Natural Resources Canada, Geological Survey of Canada (Atlantic), Bedford Institute of Oceanography, Dartmouth, Nova Scotia B2Y 4A2, Canada

Late Jurassic-Early Cretaceous deltaic sandstones are important oil and gas reservoirs in the Scotian Basin, offshore Nova Scotia. These sandstones were deposited in response to, and thus cryptically record, the evolution of the North Atlantic rift and associated changes in palaeodrainage along the Canadian passive margin. Determining the provenance of these deltaic sandstones, therefore, not only helps to constrain the timing and location of uplift but also enables us to assess the footprint and relative contribution of individual drainage systems and gain insights into potential reservoir quality since source rock composition asserts a primary control on reservoir quality.

Previous provenance studies using geochemical (both bulk and heavy mineral varietal studies), geochronological (zircon, muscovite, monazite) and petrographic analysis of Jurassic-Cretaceous sandstones have been hampered by widespread polycyclic reworking. The current study builds upon this work by fingerprinting $\mathrm{Pb}$ isotopes in detrital feldspar, which record first-cycle supply. The study demonstrates the importance of coupling individual tracers of varying resilience to unravel sedimentary provenance. This study also assesses the utility of the $\mathrm{Pb}$ in feldspar approach, including the application of $\mathrm{Pb}$ isotopes in detrital plagioclase and diagenetically altered (albitised) grains observed at depths below $2 \mathrm{~km}$. The study uses mostly core samples from over ten wells across the basin, from Mohawk B-93 in the west to Bandol No.1 in the east.

Characterisation of detrital feldspar $\mathrm{Pb}$ isotopic compositions clearly demonstrates changes in supply linked with regional topographic variations as a result of the evolving Labrador Rift. A sharp change in the Late Jurassic from Appalachian to Grenville signatures is recorded across the basin but does not mask locally important contributions from proximal sources, particularly in the west of the basin. In the central Sable and eastern Abenaki depocentres, more long-distance sourcing from older Grenvillian rocks to the north is indicated by a single $\mathrm{Pb}$ population, raising questions about the independent roles of the proposed paleo-Sable and paleo-Banquereau rivers. 


\section{Margin segmentation during polyphase rifting in the southern Bay of Biscay}

\section{Patricia Cadenas ${ }^{1}$, Gianreto Manatschal ${ }^{1}$, Gabriela FERNÁNDEZ-VIEJO ${ }^{2}$, AND J. KIM WELFORD ${ }^{3}$}

1. Institut du Physique du Globe de Strasbourg (IPGS); UMR 7516, Université de Strasbourg/EOST, CNRS, Strasbourg 67084, France g 2. University of Oviedo, Department of Geology, C/Jesús åArias de Velasco, $s / n$, Oviedo 33005, Spain g

3. Department of Earth Sciences, Memorial University of Newfoundland, St. John's, Newfoundland and Labrador A1B 3X5, Canada

There is broad agreement that the structure of rifted margins results from the evolution of successive deformation modes linked to tectonic activity. However, the progressive spatial and temporal evolution of rifting leading to strain localization and structural segmentation are still poorly understood. The strongly segmented Bay of Biscay rift system represents a valuable setting in which to study and characterize the evolution of extensional processes and the architecture of a polyphase rift system that evolved to lithospheric breakup. This system developed during the Mesozoic as part of the southern North Atlantic rift. Its central V-shaped oceanic basin was formed during a short-lived spreading period preceded by Triassic to late Early Cretaceous polyphase rift events. The system was subsequently inverted to various extent during the Alpine orogeny due to the convergence between Iberia and European plates.

In this work, we present the structural framework and the tectonic evolution of the North Iberian margin/southern Biscay margin. To build this framework, we relied on the interpretation of a dense set of high quality 2D seismic reflection profiles, together with boreholes and published wide-angle models, and lithospheric density constraints derived from 3D gravity inversions. The margin shows a distinctive structural variability and a strong segmentation resulting from three extensional events. Remnants of an early Permian-Triassic rift have been identified along the continental platform. A rift basin related to a PermianTriassic rift is suggested in the western platform. During a second Late Jurassic to Early Cretaceous rift event, localized hyperextension resulted in narrow and deep basins such as the Asturian and the Parentis basins, located in the central and eastern North Iberian margin. During a last late Early Cretaceous rift event, extreme crustal thinning and exhumation gave way to the onset of seafloor spreading and the formation of an oceanic basin.

The results of our study suggest that the Bay of Biscay rift system formed as a result of a complex and polyphase evolution. The observed segmentation arose from a strong partitioning of deformation and a progressive strain localization during rifting that conditioned the subsequent compressional reactivation of the margin.

\section{Seismic stratigraphy and architecture of the Jurassic Abenaki margin, and potential for distal organic-rich facies}

\section{T. J. Campbell, G. D. Wach, F. W. Richards, AND R. L. SILVA}

Basin and Reservoir Lab, Department of Earth Sciences, Dalhousie University, Halifax, NS B3H 4R2, Canada

Well and core data, 3D seismic data, and geologic analogs (Portugal and Morocco) are used to test and extend stratigraphic concepts of a mixed clastic-carbonate depositional setting during the Middle Jurassic to early cretaceous in the Sable Sub-basin, offshore nova Scotia. The study focuses on basinward mapping of third-order depositional sequences in the Abenaki carbonate bank, and addresses: (1) source rock potential in coeval basinal calcareous mudstones; (2) changes in bank margin morphology related to the basement; (3) transition from a dominantly carbonate to fluvio-deltaic system extending into the late cretaceous; and (4) the presence of thick fluvio-deltaic sediments adjacent to basinal mudstones outboard of the carbonate bank.

Geological, petrophysical, and geophysical methods are used to interpret the depositional cycles and stratigraphic framework of limestones and calcareous shales deposited in deeper water outboard of the Abenaki margin. This framework formed the basis for a 3D geocellular model populated with lithologies from well data via a seismic inversion. This model was interpreted in terms of environments of deposition and source rock potential.

The third-order sequence stratigraphic framework was modified from a framework established by encana at their Deep Panuke gas field. This thirdorder chronostratigraphic (Abenaki 1-7) framework incorporates multiple litho-stratigraphically defined formations: the Mohican, Mohawk, Mic Mac, Abenaki, Missisauga, and Verrill canyon. Thick fluvio-deltaic successions adjacent to basinal mudstones, as seen in the Migrant n-20 well, are structurally controlled, with deposition in local depocentres in response to sediment loading and listric faulting above a deeper mobile salt substrate.

Based on published carbonate depositional models, distal condensed sections in the Abenaki 1-4 sequences (Bajocian-Kimmeridgian) have the potential for accumulations of organic-rich sediments. The basinal 
shales of these sequences are estimated to have been deposited in up to $200 \mathrm{~m}$ water depths and have potential as type ii source rocks. A change in seismic signatures and facies occurs between Abenaki 1-4 and Abenaki 5-7 sequences reflecting encroachment of the Sable Delta. Abenaki 5-7 sequences (Kimmeridgian-Berriasian) are interpreted to have potential for a predominantly type iii source, with some potential for type ii sources in intervening calcareous mudstones.

\section{Frontier exploration in the Peniche Basin (West Iberia Margin): new insights from recent 3D seismic and Grav-Mag modeling}

\section{João Casacão, Susana Fernandes, Francisco Silva, AND JOÃO ROCHA}

Galp Energia, Rua Tomás da Fonseca, Torres de Lisboa, Torre Galp - 5० Andar, Lisbon, Portugal

The deepwater Peniche Basin, located along the West Iberia Margin (WIM), has been one of the exploration focus areas on the southern North Atlantic during the last decade. The basins of the WIM are compared broadly to other hydrocarbon prolific conjugates, such as the Jeanne d'Arc and Flemish Pass basins, the Porcupine and Rockall Trough basins, and the Essaouira/Aaiun-Tarfaya basins. Still underexplored, the northern sector was recently surveyed with a $3200 \mathrm{~km}^{2}$ set of 3D seismic and gravity-magnetic data, which were used to unravel distinct geological aspects over the area's main depocentre. Although the stratigraphic record should likely resemble the contiguous Lusitanian and Porto basins, some lithological variations are expected, reflecting the basinward deepening from the rift-climax phase onwards.

The opening of this half-graben trough at this sector of the Peniche Basin is controlled by horizontal and vertical interactions, between the deeply-rooted ENE-WSW Aveiro Fault, NNW-SSE and NE-SW structures. Its main rotation phase is linked with the rift-climax phases during the Late Jurassic to Early Cretaceous, probably associated with local crustal shortening. Potential field data modeling was incorporated into this study, helping to identify the main structural families and assessing the nature of the preMesozoic basement. Seismic interpretation was particularly challenging due to the massive occurrences of salt pillows and diapirs, which impose strong deformation on the Early/ Middle(?) Jurassic sequences. Based on our analysis, a thick Upper Jurassic wedge sequences is developed within the hanging-walls of the Porto Seamount horst feature and the Aveiro Fault, before a more uniform Cretaceous and Tertiary cover. Complex salt tectonics accompany the higher subsidence pulses with associated thicker sedimentation, and diapiric reactivations during the Tertiary compressive phases until present-day.

Based on regionally proven petroleum systems and conjugate analogs, Jurassic and Cretaceous source-rocks were considered and maturity and expulsion models were performed. According to the estimated thermal regime, results point out for mature and overmature source-rocks, which should already have reached most of its ultimate expulsion potential.

\section{Early rift architecture and the creation of accommodation space: insights from the Nova Scotia margin, Atlantic Canada}

\section{Pablo Cervantes, Paul Whitehouse, Tim Grow, Patrick Loureiro, and Roy Fitzsimmons}

Hess Corporation, Houston, Texas 77010, USA

After a period of sustained stretching in the Late Triassic, Pangea finally separated during the early Jurassic. In Nova Scotia (and its conjugate margin in Morocco), initial stretching created locally thick salt basins which foundered as breakup occurred. Within 2D and 3D seismic datasets, discrete structural provinces, (undeformed, necked, hyper-extended, exhumed, and oceanic) are identified that controlled the distribution of salt basin development. Additionally, the post-breakup paleo-bathymetry reflected the inherited structural grain and early salt movement, both leading to the development of discrete sedimentary fairways. Detailed mapping within the Jurassic stratigraphy offers understandings on how complex salt basins develop, and provides insights into areas where imaging is more challenging.

Hydrocarbon and aqueous fluid inclusion signatures in well cuttings from Newfoundland and Labrador's offshore basins

\section{Alessandra Costanzo ${ }^{1}$, J. Hunt ${ }^{1}$, M. Feely ${ }^{1}$, D. H. WILTON ${ }^{2}$, AND D. NORRIS ${ }^{3}$}

\author{
1. Earth and Ocean Sciences, School of Natural Sciences, National \\ University of Ireland, Galway LL32 8FA, Ireland 9 \\ 2. Department of Earth Sciences, Memorial University \\ of Newfoundland, St. John's, Newfoundland and Labrador \\ A1B 3 X5 Canada 9 \\ 3. Nalcor Energy Limited, 500 Columbus Drive, St. John's, \\ Newfoundland and Labrador A1B 0C9, Canada
}


Fluid inclusion (FI) studies play an important role in the understanding of fluid dynamics within sedimentary basins and can help to constrain the fluid migration history of a basin by providing information on the chemistry of the fluids, temperature and pressure conditions within the basin and relative timing of hydrocarbon and aqueous fluid migration events.

Fluid signatures of quartz-hosted FI were obtained from 167 samples of well cuttings taken from seven legacy wells in the Newfoundland and Labrador offshore basins. The basins are part of a series of conjugate sedimentary basins formed by the rifting and seafloor spreading that began in the Late Triassic, leading to the opening of the Atlantic Ocean. The sampled wells are (D.\# $=$ CNLOPB well identifier number): (1) Saglek Basin: Gilbert F-53 (D.64), Skolp E-07 (D.55), and Ogmund E-72 (D.70); (2) Hopedale Basin: Snorri J-90 (D.47), and Herjolf M-92 (D.53); (3) East Orphan Basin: Margaree A-49 Well (D.384); and (4) South Whale Basin: Lewis Hill G-85 Well (D.283).

Five FI types are recognised that are either primary, pseudosecondary, or secondary in origin. Type 1, Type 2 and Type 3 are aqueous FI and occur in all wells. Type 4 and Type 5 are hydrocarbon-bearing FI and are present in some samples from the Gilbert, Herjolf, and Margaree wells. Ultra-violet light microscopy of the hydrocarbon-bearing FI reveals an API gravity that ranges from $\sim 30^{\circ}-35^{\circ}$ (yellow/ green fluorescence) to $45^{\circ}-50^{\circ}$ (blue/white fluorescence) suggesting the trapping of medium to light oils.

Type 1 two-phase (Liquid + Vapour $=\mathrm{L}+\mathrm{V} ; \mathrm{L}>\mathrm{V}$ ) aqueous FI predominate in all well samples, homogenize to the liquid phase $\left(\sim 60^{\circ} \mathrm{C}\right.$ to $\left.150^{\circ} \mathrm{C}\right)$ and have salinities of $<10$ eq.wt.\% $\mathrm{NaCl}$. Furthermore, Type 1 define two populations in some wells (Population A: $80^{\circ} \mathrm{C}$ to $120^{\circ} \mathrm{C}$; Population B: $120^{\circ} \mathrm{C}$ to $160^{\circ} \mathrm{C}$ ) suggesting cyclical temperature fluctuations during the development of the Saglek, Hopedale and East Orphan basins. Coeval trapping of hydrocarbon and aqueous FI, e.g., the Gilbert well, facilitated the generation of isochores for both fluid types indicating the trapping of oil and aqueous fluids at $\sim 380$ to 460 bars and at temperatures of $\sim 110^{\circ} \mathrm{C}$.

Finally, these results will be combined with ongoing FI studies of other wells and discussed to provide insight into petroleum system development within frontier regions of Newfoundland and Labrador's offshore. This insight can be used to de-risk elements of the petroleum system within assessment regions where little data exists.

Oil seepage mapping in the Pernambuco Plateau, Brazil: accessing the structural control on hydrocarbons migration and accumulation
Alves Hewerton Da Silva, Jose Antonio Barbosa, Osvaldo Jose Correia Filho, Bruno Varela Buarque, and Jefrerson Tavares Cruz Oliveira

Federal University of Pernambuco, Avenue Prof Morais Rego, 1235, Cidade Universitária - Recife / Pernambuco 50670-907, Brazil

The Pernambuco Basin represents a new exploration frontier in northeastern Brazil covering approximately 24 $000 \mathrm{~km}^{2}$. The deepwater region of the Pernambuco Plateau comprises deep grabens (up to $8 \mathrm{~km}$ ) and large outer highs, and has high petroleum potential. This investigation presents results of oil seepage mapping in the Pernambuco Plateau, and an analysis of seep locations and the regional structural framework of the basin. The investigation aimed to verify the control exerted by regional structures on the migration/accumulation of hydrocarbons.

The investigation of oil seeps was based in the analyses of 58 SAR satellite images produced by the ENVISAT satellite, provided by the European Space Agency (ESA). The images cover a period from 2004 to 2007, with each comprising an area of $65 \mathrm{~km} \times 65 \mathrm{~km}\left(4225 \mathrm{~km}^{2}\right)$. Thirty-one anomalies were found, and multi-criteria analysis suggests that 20 are associated with natural seepage from hydrocarbon accumulations formed by an active petroleum system.

The first group of anomalies is concentrated in the northern part of the plateau, associated with the fault system that forms the eastern border of the Maracatu High that trends NNE-SSW. A second group of oil seeps occurs in the northeastern region of the plateau, around the Itamaracá Outer High, associated with the fault system controlling the western border of the high. A third group of seeps is associated with the fault system of the eastern border of the Gaibu Outer High, a basement topographic high in the central region of the plateau. A fourth group of seeps is located in the southwestern region of the plateau, near the Maragogi-Barreiros High, that trends NW-SE. A fifth group of seeps occurs along the outer border of the plateau, and probably is not related to deep hydrocarbon reservoirs. These anomalies are possibly related to hydrothermal seeps. The seepage cluster found along the border of the Maracatu High shows strong correlation with three oil exudations found through the piston-core research campaign conducted by the National Petroleum Agency (ANP) in 2005.

The mapping of natural seeps revealed the occurrence of seep clusters in the northern, southern, and central regions of the Pernambuco Plateau, and that fault systems that controlled the main depocentres probably acted as migration corridors in the basin. The results can reduce exploratory risk, as well as support future petroleum system modeling. 


\section{A clinoform trajectory model for Late Cretaceous and Cenozoic sedimentation on the Labrador-Baffin Island margins, Canada}

Lynn T. Dafoe, Kate Dickie, and Graham L. Williams

\section{Natural Resources Canada, Geological Survey of Canada (Atlantic), Dartmouth, Nova Scotia B2Y 5A2, Canada}

The Labrador-Baffin Seaway formed when Greenland pulled away from the North American Plate in the Early Cretaceous, with earliest seafloor spreading commencing in the Maastrichtian and ending by latest Eocene time. As a result of this shared rift history, integration of well and seismic information on the Labrador Margin can help elucidate stratigraphic trends for the broader frontier region. We present a Late Cretaceous through Cenozoic clinoform trajectory model for this margin that highlights major regressive/transgressive events.

Paleoenvironmental and biostratigraphic analyses are combined with seismic interpretation to identify shoreline clinoforms and shelf-edge breaks. The clinoforms display a variety of morphologies including: high-angle offlapping lobes; long wavelength, low-angle lobes; and complex aggradational clinoforms. The Late Cretaceous transgression is characterized by two backstepping shoreline clinoforms with maximum flooding reached in the Maastrichtian. A major Selandian to basal Eocene regression forces the shoreline basinward forming two distinct progradational units. Relative sea level rises with an early Eocene transgression forming a Ypresian clinoform near the basin margin, which is further onlapped as the shoreline is pushed landward beyond the limitations of the data. Slow progradation and aggradation ensues, but is punctuated by a regression in the Bartonian forming lowangle, progradational shoreline clinoforms, a shelf-edge break, and distal fan deposits. The Bartonian shoreline is transgressed and overlain by a thick late Eocene to early Oligocene aggradational and progradational package interrupted by minor flooding events. The base of the Chattian is coincident with another major regression and development of an aggradational, "shelf-edge delta"-type clinoform comprised of two stacked lobes and a related fan deposit. Transgression in the early Miocene caps this clinoform, and is followed by a middle Miocene regression producing another aggradational clinoform and related fan deposits. Plio-Pleistocene cooling and concomitant drop in global sea level forces the shoreline far seaward to form the current day shelf edge.

Our model helps to refine the stratigraphy of the Labrador Margin, but can also be linked to offshore studies in Baffin Bay where sampling is more limited, as well as onshore sections of the adjacent Bylot Island (Canada) that preserve proximal equivalents.

\section{Post-rift potential source rock correlations and prospectivity of the deep Atlantic conjugate margins south of the Walvis Ridge}

\section{Ian Davison and D. Wallace}

\section{Earthmoves Ltd., 38-42 Upper Park Road, Camberley, Surrey GU15 2EF, United Kingdom g \\ 2. Chariot Oil and Gas Ltd., 19-21 Bond Street, London W1S 4PX, United Kingdom}

Several isolated, small half-grabens $(5-10 \mathrm{~km}$ wide and 1-2 km deep) are present along the conjugate margins of the South Atlantic south of the Walvis Ridge that were produced by Early Cretaceous rifting. These half-grabens can contain source rocks (e.g., the AJ-1 well in South Africa); however, their areal extent is restricted. The main accommodation space created by Early Cretaceous extension is filled by magma that produced seaward-dipping reflectors (SDRs). The upper part of the SDRs were drilled in the Walvis and Pelotas basins and consists of subaerial reddened basalts. No source rock potential has been encountered, nor is any expected in such a subaerial sequence. Hence, the hydrocarbon prospectivity of the deepwater margins will largely rely on the presence of postrift source rocks.

Early drift, Barremian to Aptian age marine source rocks were identified in several wells including the recent Murombe-1, Wingat-1 and Moosehead-1 wells, where residual TOC levels up to $6 \%$ in source packages of up to $150 \mathrm{~m}$ were measured. The deposition of this source rock is interpreted to be widespread in the deepwater. It is modelled as oil-mature in several large kitchen areas currently located in water depths from less than $500 \mathrm{~m}$ to greater than 3000 $\mathrm{m}$. Additionally, good quality Cenomanian to Santonian age source rocks are identified in several wells offshore Namibia. The 1911/15-1 well has TOC levels reaching up to $10 \%$ and a gross thickness of $170 \mathrm{~m}$, and the Kabeljou- 1 well an average TOC of $5.3 \%$ of approximately $50 \mathrm{~m}$ thickness.

The Barremian to Aptian age source rocks on the Namibian margin are now recognized to be the principal source rock for future exploration drilling and are characterized by parallelbedded, low amplitude, low frequency, continuous lowimpedance reflectors, which lie above the SDRs. The Aptian section above the SDRs in the deepwater $(>2 \mathrm{~km})$ PelotasArgentine margin has never been drilled, but seismic data indicates a similar stratal package. Recent 2D/3D seismic data from Namibia will be used to characterize the source rock package and compare with recently acquired seismic data from Argentina and Uruguay. 
Salt-sediment interaction in the central basin of the Nova Scotia passive margin, offshore eastern Canada

\section{Carole C. Decalf, Charles H. Bondurant, and Philip BUNTING}

\section{BP, 225 Westlake Park Boulevard, Houston, Texas 77079, USA}

On the passive margin of Nova Scotia, offshore eastern Canada, salt tectonics play a significant role regarding the occurrence of trapped hydrocarbons. Latest Triassic salt deposition and its subsequent movement influenced the structural framework and the sediment distribution along the margin during the last $200 \mathrm{Ma}$. Complex tectonic activity and the concurrent development of major delta systems influenced the distribution, timing, and style of potential hydrocarbon-bearing structures and inherent reservoir intervals on the paleo-slope, especially during the Jurassic and Cretaceous time frame.

In the Scotian Basin, the Triassic Argo salt is interpreted to be late synrift to early postrift in age. Its deposition, thickness, and potentially also its composition varies from the eastern to the southern part of the Scotian Basin depending on the original rift structure and orientation. Allochthonous salt canopies initiated as early as Middle to Late Jurassic in the Banquereau synkinematic wedge and are interpreted to appear at a later stage in the central part of the margin.

Recently, modern 3D wide azimuth towed streamer (WATS) seismic survey acquisition data over an area of approximately $7000 \mathrm{~km}^{2}$, was processed with latest techniques such as reflection full waveform inversion (FWI). This process generated a major uplift in the imaging and resulted in better definition of the salt structure in the central basin. It supports the view that the Argo salt experienced an early deformation and allochthonous canopy emplacement by Middle to Late Jurassic not only in the eastern but also in the central part of the basin. Following this was a period of active diapirism responding to Cretaceous sediment loading and subsequent final shallow canopy formation by Late Cretaceous time. Additionally, seismic facies observations correlated between salt minibasins within a stratigraphic framework and tied with sparse well control provide a better understanding of the sediment deposition between the paleo-salt highs, especially in the central part of Nova Scotia but also all along the wider passive margin.

This study proposes an integrated approach on salt deformation and sediment interaction using the latest 3D seismic processing technology as well as Moroccan outcrop analogues to understand better the distribution and evolution of the salt. It identifies and discusses various salt trap domains and their implication on sediment transport in the Central basin of Nova Scotia.
The 'Helmut' geophysical anomaly: a regional transfer zone connecting Santos and Campos basins, southeastern Brazil

Nolan Maia Dehler, Felipe Domingues da Costa, Leonardo Correia Gomes, Caesar Rigoti, João Alberto Bach Oliveira, and Marília Vidigal Sant’anna

Petrobras Exploration. Ed. Ventura. Av. Chile 330, 130 andar. Centro, Rio de Janeiro, CEP: 20031-170, Brazil

In the ultra-deepwater of Santos and Campos basins, eastwards from the area of present-day pre-salt exploration in southeastern Brazil, there is a nearly $1000 \mathrm{~km}$ long curved magnetic anomaly named 'Helmut'. On a magnetic map, the anomaly orientation switches from NE-SW in Santos Basin to nearly N-S in Campos, mimicking the curved Neoproterozoic shear zone pattern of the basement exposed onshore. From the comparison between the position of such anomaly and gravity-derived modeling and residual maps, it is suggested the magnetic anomaly also corresponds to a major gravimetric boundary separating different crustal domains. This boundary is slightly oblique to the rift-related normal fault trend in Santos Basin. Based on interpreted 3D seismic data, the NNE-trending normal faults are dragged to the NE direction close to the magnetic anomaly in southern Santos Basin, where an en echelon array of oblique magnetic anomalies occurs that resulted mainly from the left lateral component of an overall transtensional displacement field.

In regional $2 \mathrm{D}$ deep reflection seismic profiles, the 'Helmut' anomaly is correlated with major eastwarddipping, down-to-the-basin stepped faults in some places arranged in a fan-like fashion in Santos Basin, and as a landward dipping normal fault zone in Campos Basin north of the E-W Araruama transfer zone. In some areas, the fault zone displaces the base salt reflector and crosscuts the entire stretched continental crust. The analysis of potential field and seismic data suggests that the 'Helmut' anomaly may be interpreted as a crustal-scale, low-strain shear zone system active during and after salt deposition in the Late Aptian. Regionally, the 'Helmut' anomaly connects two approximately N-S trending branches of the South Atlantic Rift System: 1.) the northern branch that runs from Espírito Santo basin northwards up to the Camamu (south of the Recôncavo-Tucano-Jatobá aborted trough); and 2.) the southern branch running southwards from Santos basin through Pelotas basin in Brazil as far as the basins offshore Uruguay and Argentina basins southwards. We suggest that the 'Helmut' line corresponds to a major, transfer system connecting both regional rift branches.

Extensional faulting of the base salt reflector along early NNE rift-related normal faults and dextral transtension on the NW-trending fault zones are all consistent with a sinistral transtensional motion on the NE-trending 'Helmut' anomaly during the Late Aptian. 


\section{Insights into crustal structure and rift basin development off central and western Nova Scotia, Canada - a reflection seismic perspective}

\section{Mark E. Deptuck}

\section{Canada-Nova Scotia Offshore Petroleum Board, Suite 800, TD Centre, 1791 Barrington Street, Halifax, Nova Scotia B3J 3K9, Canada}

The assembly and interpretation of an extensive reflection seismic dataset, collected mainly for hydrocarbon exploration over the past five decades, reveals new details about the crustal structure offshore Nova Scotia as well as the fill and development of overlying Triassic to Early Jurassic rift basins. Combined with the correlation, gridding, and depth conversion of the top of pre-Carboniferous crystalline basement, a widespread reflection consistent with a top mantle reflector (reflection Moho), and a number of subhorizontal mid-crustal shear zones and synrift markers, a clearer picture is emerging about how the crust off Nova Scotia accommodated lithospheric extension and evolved from the synrift to postrift.

The results provide a direct measure of crustal thickness and insight into the distribution and character of brittle versus ductile crust, and show development of a distinct, segmented, and locally branching Moho high that tracks beneath the primary salt basin along the central and western parts of the margin. Brittle upper crust is thickest above platformal areas, where ten separate synrift basins developed. Flanking these are important border faults soling into multitiered mid-crustal shear zones probably corresponding to reactivated Paleozoic structural fabrics. Border faults are dominantly landward-dipping with subordinate seawarddipping border faults flanking segments of some basins. The thickness of brittle crust diminishes abruptly beneath the present day slope, in some cases with highly rotated crustal blocks transported as rafts above comparatively thick intervals of ductile lower crust. In contrast to the platform, there are clear alternations between dominantly landwardand dominantly seaward-dipping border faults on the slope. Gaps between some brittle crustal fragments result in synrift strata directly overlying ductile crust.

There are some indications that lower crustal flow and deformation of overlying brittle rafts continued well into the Jurassic - in some cases providing a mechanism for postrift inversion. Layers of complex bright amplitude seismic reflections commonly veneer brittle rotated crustal blocks and are interpreted as volcanic rocks emplaced before or during the earliest periods of salt accumulation. The increased occurrence of suspected volcanic rocks may reflect enhanced melt production where the crust is thinnest, approaching the Moho high that underpins the primary salt basin.

\section{The Taconic and Grampian orogenies: Ordovician arc- continent collision}

\section{JoHn F. DeWEY}

\section{University College Oxford, High Street, Oxford, Oxon OX1 4BH, United Kingdom}

The Ordovician and Cretaceous were periods of dispersed continents, high sea-level, platform carbonates, oceanic black shales, blueschists, and fore-arc supra-subductionzone ophiolite complexes obducted, with their associated arcs, onto continental shelves, as giant thrust sheets up to 200 $\mathrm{km}$ normal to and $1000 \mathrm{~km}$ parallel with regional orogenic strike, during arc/rifted continental margin collision. The ophiolite sheets have associated regional subjacent polyphase-deformed Barrovian metamorphic complexes, transported high-temperature two-pyroxene granulite/ amphibolite basal soles, and blueschist assemblages. The metamorphic soles, which have MORB and OIB protoliths have ages roughly the same as the ophiolite above and are derived clearly from the subducting ocean, sliced off and attached to the base of the ophiolite before obduction. The soles are not metamorphic aureoles to the oducting hot ophiolite because they originated at pressures up to about 10 $\mathrm{kb}$. The obducted sheets and their subjacent orogenies were short-lived continentward-vergent events and led, along the Laurentian margin of the Appalachian/Caledonian Orogen, to subduction polarity flip and vergence reversal. These short-lived collisional orogenies were accompanied by the development of flexural peripheral bulges, and foreland basins that received detritus from the rapidly eroding orogen.

The recent acquisition of a large amount of new stratigraphic, structural, geochronological, and heavy mineral data for the Ordovician Taconic/Grampian Zone of the Appalachian/Caledonian Orogen has resulted in a detailed understanding of the timing and relationships between ophiolite generation and obduction, deformation, metamorphism, magmatism and unroofing, which now permits fine-scale control of iterative numerical models of the obduction process and its geological consequences. A series of thermo-mechanical models have been developed for ophiolite obduction, resulting from arc/continent collision, based upon geological data from the Grampian Zone of the British Caledonides and the Taconic Zone of the Newfoundland Appalachians that accounts for their stratigraphy, structure, metamorphism, magmatism, geochemistry, and burial/exhumation history over a short orogenic episode of about twelve million years. Western Newfoundland preserves, superbly, most elements of the Taconic arc-Laurentian continental margin collision including continental edge facies changes, the obducted 
fore-arc Bay of Islands Ophiolite Complex, the Goose Tickle foreland basin, the arc, and the superposed polarity-flip arc. Western Ireland preserves the South Mayo Trough, some five kilometres of clastic and volcanic rocks and a major Barrovian metamorphic complex beneath the obducted arc. In western Newfoundland, there appear to have been two sub-parallel subduction surfaces; one shallow along which the arc and fore-arc were obducted, the other at a deeper level along which the Grenville basement was stripped from beneath the amphibolite-facies Fleur-de-Lys metamorphic complex and carried down into the eclogite facies before being educted back against the Fleur-de-Lys.

Full-fit reconstruction of the central Atlantic

\section{Naila Dowla, Dale E. Bird, and Michael A. Murphy}

Department of Earth and Atmospheric Sciences, University of Houston, 3507 Cullen Blvd \#312, Houston, Texas 77007, USA

Numerous plate reconstructions for the Central Atlantic have been proposed over the past half century. While these reconstructions use observable features to refit the North American plate with the African plate, few studies incorporate vertical crustal deformation or crustal thinning into their plate models, employing simplistic layer geometries and properties that limit deformation estimates. To improve upon this approach, a six-layer 3D crustal model of the Central Atlantic margins was built using potential fields to estimate depth to Moho and crustal thickness. Using these results, a new, full-fit plate reconstruction model of the Central Atlantic is presented, in which present day extended continental crust is restored to prerift thicknesses and geometries.

The 3D crustal model for the North American margin shows Triassic rift basin connectivity along strike. The 3D crustal model for the African margin shows that crustal thinning continues landward all the way to the Mauritanides mountain belt. Our results shift previously proposed limits of crustal deformation landward by $\sim 350 \mathrm{~km}$ on the African margin, and $\sim 150 \mathrm{~km}$ on the North American margin. Based on reconstruction overlaps and gaps between the two plates, magmatic and/or amagmatic histories can be estimated. Sections of the margin characterized by reconstruction overlap suggest magmatic activity during formation. Conversely, gaps along the reconstructed margins suggest mantle exhumation. Our 3D method provides a context for examining great lengths of conjugate margin development, from rift to drift. Specifically, our 3D method provides a framework for further studies in the Central Atlantic; examples might be the East Coast Magnetic Anomaly and the amagmatic Newfoundland margin.

\section{Facies, stratigraphic evolution and dolomitization of the Jurassic carbonate system, Agadir-Essaouira Basin, Morocco: an outcrop analogue for the Central Atlantic margin}

\section{Aude Duval-Arnould, Nawwar Al-Sinawi, Stefan} SChröDER, CATHy Hollis, and JONATHAN REDFERN

School of Earth and Environmental Sciences, Basin Studies and Petroleum Geoscience, North Africa Research Group, University of Manchester, Oxford Road, Manchester M13 9PL, United Kingdom

Upper Jurassic carbonates are proven yet poorly understood reservoirs on the Moroccan and Canadian Atlantic conjugate margins. This study details extensive sedimentologic, biostratigraphic, petrographic, and geochemical analysis in the Agadir-Essaouira Basin (AEB) to characterize facies distribution, develop models for stratigraphic evolution, and constrain reservoir architecture. This study is integrated with a study of the controls on the origin and distribution of dolomitization, of key economic importance for reservoir producibility.

Basalt of the Central Atlantic Magmatic Province (CAMP) marks the transition to Jurassic postrift deposits. In the Essaouira Sub-basin, the first Jurassic deposits are Sinemurian open marine carbonates. Basal Toarcian continental deposits record a major regressive phase eroding into the CAMP basalts. The overlying transgressive Toarcian Id Ou Moulid Formation is marked by development of shallow-water carbonates with well-preserved evaporites on the margins of the basin, alternating with stratabound dolomitized mudstones and oolitic carbonates. The dolostones are characterized by replacive euhedral-anhydral dolomite crystals formed by reflux of low temperature dolomitizing fluids $\left(<50^{\circ} \mathrm{C}\right)$. Towards the centre of the basin, evaporites were replaced by dissolution breccias and kerogenic stromatolite horizons.

The Middle Jurassic (Dogger) Ameskhoud Formation records another regressive phase with deposition of fluvial successions, followed by a Callovian transgression. It establishes the extensive prograding carbonate platform culminating in a marl unit before the Oxfordian. Open marine deposits of the Oxfordian Tidili Formation outcrop along the crest of exposed anticlines that allow the characterisation of build-ups geometries and internal facies organization. The Oxfordian limestones can be pervasively dolomitized with two phases observed: replacive (euhedralanhderal) dolomite suggestive of low temperature shallow burial dolomitization, and fabric destructive (saddle) dolomite that developed coevally with hydrocarbon migration. The later formed under elevated fluid temperature $\left(>50^{\circ} \mathrm{C}\right)$ suggesting a fault-related hydrothermal source.

This integrated study facilitated refinement of the AEB's 
stratigraphic evolution and identify the Oxfordian as the main potential reservoir. Dolomitization of the different units enhanced the porosity of host limestones but the strong heterogeneity in Oxfordian facies and fault-controlled dolomitization can reduce the porosity.

A continent-scale delta's effect on the north end of a Jurassic-Cretaceous gigaplatform: the Abenaki carbonate-Sable delta study a decade or so later, offshore Nova Scotia, Canada

\section{LESLIE S. ELIUK}

\section{GeoTours Consulting Inc., Box 852, Lunenburg, Nova Scotia B0J 2C0, Canada}

My study was to describe and understand the strange relationship of a thick extensive carbonate platform coexisting for a long time (15 Ma) beside a continent-scale delta. After finding no analogues in the modern world oceans but some interesting examples of reefs in or near deltas, an explanation was proposed to address two questions with the results not wholly convincing for the first and more satisfactory for the second. (1) morphology, nature and origin of a big delta/thick carbonate platform juxtaposition and lateral ramp carbonates. A bathymetric 'gap' best explains the systems' juxtaposition with their very different styles of carbonates. This interpretation is supported by vintage seismic data and the nature of the transition shown in well sections and cores. More work can be done using newer and better seismic data sets, and by considering with modelling the effect of deltaic sediment loads on creating a lateral moat and potential compensatory distal highs. Another possible control in the modern is favourable ocean currents but not easily proved in the ancient record. (2) Possible lateral effects on platform margin carbonates due to proximity of deltaic sedimentation depends on location and can be nearly non-existent within the platform, subtle on the slope and profound, long continued and variable on the top during the expansion of the delta. This explanation is supported by the presence of rare, thin quartz sandstone beds or oolite nuclei on the main platform, the increasing influence of slope onlap prodelta shales, and some lateral changes in slope carbonates. There are also wholesale reef mound community changes at top of the Abenaki succession, but without presence of coarse terrigenous clastics. Further features such as common reworked microfossils, Neptunian dykes, and condensed marine redbeds indicate that the distal sedimentary section may be more gap than record with both submarine and subaerial hiatuses even including suspect mixing zone dolomite. There seems to be a consistent diachronous relationship to prodeltaic siliciclastic, sponge- rich, and marine redbed successions.

The world's longest modern coral reef tract, Australia's Great Barrier Reef, ends in the Fly River Delta of the Gulf of Guinea (Tcherepanov et al. 2008, 2010). The world's largest river, Brazil's Amazon, has a long, narrow but cryptic reef tract on the edge of its wide continental shelf (Moura et al. 2016). While not platforms, these modern examples give insight into the deltaic termination of the Phanerozoic's longest carbonate platform.

\section{Thin carbonates in thick siliciclastic successions: a useful key to depositional environments and sequence breaks as revealed by two core examples (\#9 limestone in South Desbarres O-76 and West Venture N-91 wells) from the Jurassic-Cretaceous offshore Nova Scotia, Canada}

\section{LESLIE S. ELIUK}

\section{GeoTours Consulting Inc., Box 852, Lunenburg, Nova Scotia B0J 2C0, Canada}

Paleogeography and climate make Mesozoic and Recent carbonates rare in Canada. High sediment supply with resulting inimical conditions make carbonates very rare in deltas. Yet during the Jurassic-earliest Cretaceous, offshore Nova Scotia had Canada's only large Mesozoic carbonate platform, and also a thick extensive continent-scale delta with rare thin limestone layers.

Limestone in dominantly terrigenous depositional environments can have a variety of origins. As sediment mainly resulting from in situ biological processes ('born not made'), carbonates can be sensitive indicators of their depositional setting. As such they have great potential often overlooked to aid in the interpretation of the depositional environment and geological history of the associated siliciclastics. Two thin carbonate examples in core within the Sable Delta illustrate this potential.

Cores at the base of West Venture C-62 sample a shelfmargin delta complex and bottom in the \#9 Limestone that defines base of the Missisauga Formation (Berriasian to Barremian). Rather than a condensed unfossiliferous mudstone as once interpreted, the limestone showed a series of facies changes vertically from Zoophycus-burrowed marl through microbial mound into a bored deep-water spongemicrosolenid coral reef-red algal reef capped by a pyritized hardground and buried in prodelta mud. Since these shoaling changes occurred over just $10 \mathrm{~m}$, they support the idea of a major relative sea level fall (forced regression) that was previously suggested for other reasons.

The other example is core from South Desbarres O-76 that has thicker limestone beds formed on ramps lateral to the delta during delta switching with lithologies only seen 
in cuttings. However within coarse terrigenous sediments previously logged as channels there are transported sponge and bryoderm sediments that elsewhere occur in reddened shales and an in situ bioeroded multi-coral reeflet. These show minor varied organic growth and times of nondeposition in channels from fossil communities of different origins and depths.

Varied carbonate facies from the Jurassic-Cretaceous gigaplatform margin of the Baltimore Canyon Trough, offshore New Jersey, USA

\section{Leslie S. Eliuk ${ }^{1}$ and Bradford E. Prather ${ }^{2}$}

\section{GeoTours Consulting Inc., Box 852, Lunenburg,} Nova Scotia B0J 2C0, Canada 9

\section{CarTerra LLC, 715 Knox Street, Houston, Texas 77007, USA}

In 1984, three wells operated by Shell tested various types of Jurassic-Cretaceous carbonate shelf and margin plays in deep water offshore New Jersey. Eleven cores were recovered: OCS-A 0336 cores R1-4, OCS-A 0337 cores C1-3, and OCS-A 0317 cores H1-4. Representative core intervals on display are keyed to seismic morphology, and show litho-biofacies from three geometrically and stratigraphically separate shelf edges: (1) OxfordianKimmeridgian prograded margin $(\mathrm{R} 1+2)$ and slope (C3); (2) Late Kimmeridgian-Berriasian aggraded margin capped by pinnacle reefs $(\mathrm{C} 2, \mathrm{H} 3+4)$ followed by an extensive deeper-water mounded sponge-rich interval of Berriasian and Valanginian age (R2, C1, H2); and (3) a back-stepped Barremian-Aptian reef margin (R1) on prodeltaic shales.

Alternatively, cores can be facies-grouped into deeperwater upper slope microbial(?) mound (C3) and reef complex (R3-foreslope? + R4-reef framework and sands) of the prograded margin, shelf-edge shallow-water skeletal sands $(\mathrm{H} 3+4, \mathrm{C} 2)$ in the aggraded margin, and deep-water carbonates capping a drowned shallow-water shelf (R2, $\mathrm{C} 1, \mathrm{H} 2)$ then middle Cretaceous shallow-water shelf-edge oolite (R1).

Previously unpublished paleoenvironmental models by Edwin Ringer and Harvey Patten illustrate the depositional facies relationships. No analogue is perfect, but older (and with the 1999 Panuke gas discovery many more recent) Nova Scotia (NS) shelf-edge wells also sample the JurassicCretaceous gigaplatform margin. Though similar enough to apply the same formational terminology, and a very similar vertical depositional progression including 'drowning', the Baltimore Canyon wells in general sample much more carbonate-sand-rich beds. Whereas the NS margin wells sample muddier but much more reef framebuilder-rich beds. The basins have some major difference but these biofacies differences may indicate a "sampling" bias; possibly shallow- water J-K reefs simply grew in slightly deeper water. The best depositional model will integrate both data sets. Degree of dolomitization remains a significant difference.

\section{Deep crustal framework of the north-central margin of Angola}

Luiz C. L. EmpinotTi ${ }^{1}$, Pedro V. Zalán ${ }^{2}$, Monica C. P. L HeIlbron ${ }^{3}$

\author{
1. Petrobras S. A., Rio de Janeiro, Brazil g \\ 2. ZAG Consultoria em Exploração de Petróleo Ltda., \\ Rio de Janeiro, Brazil g \\ 3. GeoAtlantico Institute-TEKTOS Research Group, Rio \\ de Janeiro State University (UERJ), Rua São Francisco Xavier, \\ Rio de Janeiro CEP 20559-900, Brazil
}

The acquisition and interpretation of new seismic data over the distal parts of continental margins have allowed a better image and comprehension of the transition between continental and oceanic crusts. As a result, the classical rifting and continental breakup models have been revised and improved to create a model coherent with the existing data. In this paper, the interpretation of ultra-deep 2D seismic sections, acquired by ION-GXT and integrated with gravimetric modelling, allows the identification of the crustal limits in the central-north region of the Angola margin in the Kwanza and Lower Congo basins. Four crustal domains were defined: (1) proximal (formed by extended continental crust); (2) necking domain (where there is a rapid thinning of the continental crust); (3) distal (formed by hyper-extended continental crust and exhumed mantle); and (4) oceanic (formed by the oceanic crust). Integration of interpreted seismic data with gravity modelling and analysis of regional geological maps of the area leads to the definition of two regions with distinctive characteristics. The first area, to the north, underlies the Lower Congo Basin and is represented by an extensive distal crustal domain, presenting few basement highs affecting the thick pre-salt section. This area is related to basement rocks belonging to the West Congo Belt and reworked cratonic margins. The second area occurs to the south beneath the Kwanza Basin, and is represented by a narrower distal crustal domain displaying several basement highs affecting the thinner presalt section. The southern area is related to basement rocks belonging to the Angola Craton and to the Central Shield. 


\section{Predicting clastic plays on the USA eastern seaboard - does the northwest African margin offer insight into potential plays?}

\section{EMILY A. FirTh}

\section{Halliburton, 97 Jubilee Avenue, Milton Park, Abingdon, Oxon OX14 4RW, United Kingdom}

Clastic plays are proven within middle Cretaceous reservoirs of northwest Africa (Yakaar, SNE, and Tortue fields), the conjugate margin of the USA eastern seaboard. Strong tectonostratigraphic framework similarities on both sides of the Central Atlantic highlight the relevance of these African analogues when predicting plays on the USA margin. Given the potential expansion of offshore drilling, the prospective prize is clear. But do similar plays to those in northwest Africa exist along the USA Eastern Seaboard? To answer this, we have analyzed more than $8400 \mathrm{~km}$ of seismic data, alongside well data, in the context of regional palinspastic tectonostratigraphy. The work covers Georges Bank, Baltimore Canyon Trough, and Carolina Trough.

During the Early-Middle Cretaceous, there was uplift on both sides of the Central Atlantic. In northern Senegal and Mauritania, Albian-Cenomanian uplift of the West African Craton resulted in the deposition of clastic reservoirs of the Yakaar, SNE, and Tortue fields. Along the USA margin, significant terrigenous input from uplift of the Appalachians occurred during the middle Cretaceous. This resulted in increased potential for clastics in shelfal, slope, and basin floor settings as shown by coarse clastics in the Hudson Canyon 857-1, Hudson Canyon 642-2 and COST B-3 wells. Broad deltaic depocentres developed, and seismic data show potential updip pinchout traps, bypass of the shelf, and localized shelf uplift. These create geometries similar to the drape anticline and subcrop traps of the SNE North oil field in Albian sandstones offshore Senegal. However, vertical migration is a critical risk.

Charge is a key risk because of the burial depth of potential source rocks (Late Triassic-Early Jurassic synrift lacustrine, Jurassic, and Cretaceous OAE marine source rocks). Gas shows are present in eight of the 51 wells previously drilled in the Baltimore Canyon Trough. Early Jurassic source rocks, deposited in a restricted seaway related to the early rift phase of the Central Atlantic, are proven to produce oil in North Africa, but maturity evaluation indicates some ambiguity as to the hydrocarbon source at Tortue and Yakaar. Integration of geochemical data with our seismicderived depth framework indicates where the hydrocarbon phase from Jurassic source rocks is more likely to be oil on the USA margin. This includes localized areas of the shelf, and the deeper Georges Bank Basin and Carolina Trough, where overburden is thinner.

\section{Multiple Jurassic source intervals in the subsurface of offshore Nova Scotia, Canada}

\section{Rob ForkneR ${ }^{1}$, Andrea Fildani ${ }^{1}$, Nicholas EtTingeR ${ }^{1}$, AND JoHn M. MOLDOWAN ${ }^{2}$ \\ 1. Equinor Research and Technology, 6300 Bridge Point Parkway, Austin, Texas 78730, USA g \\ 2. Biomarker Technologies, Inc., 638 Martin Avenue, Rohnert Park, California 94928, USA}

One of the major risks when exploring for hydrocarbons is the presence of viable source rocks. This may be considered the highest risk to the success of hydrocarbon exploration efforts offshore Nova Scotia, particularly the presence of Jurassic source rocks. To de-risk source rock presence and properly characterize their depositional environments, detailed geophysical and organic geochemical analyses were performed.

The geologic evidence compiled from seismic mapping and facies analysis led us to hypothesize the presence of marine source rock facies along the continental margin of Nova Scotia at both Lower and Upper Jurassic levels. High amplitude reflections consistent with the possible occurrence of organic-rich mudrocks were identified at interpreted lower and upper Jurassic intervals. The Lower Jurassic source is interpreted to be concentrated in faultrelated half grabens slightly inboard of the subsequent Jurassic reef margin. The presence of this potential source outboard of these intervals is also hypothesized. Later Jurassic source rock is likely more regional in extent.

Comprehensive organic geochemical analyses were also undertaken to better link oils to source rocks. Eight oil samples from the Sable Island area were analyzed. We interpret the presence of at least two source rocks having contributed to the bulk of the hydrocarbon volumes in our sample set. One source rock deposited in the middle to late Jurassic and likely relates to the oil window component of the samples as well as the Upper Jurassic reflections interpreted in seismic. The second source rock is older, possibly Early Jurassic in age, has a unique diamondoid composition, and is interpreted to relate to source rock accumulation in faultrelated half grabens. 


\section{Evidence for active petroleum systems on the deepwater Scotian Slope, Canada}

\author{
Martin Fowler ${ }^{1}$, JAmie WebB ${ }^{1}$, Adam Macdonald ${ }^{2}$, \\ AND MATT LUHESHI ${ }^{3}$ \\ 1. APT (Canada) Ltd., Suite 400, 119-14th Street NW, \\ Calgary, Alberta T2N 1Z6, Canada 9 \\ 2. Nova Scotia Department of Energy, 1690 Hollis Street, \\ Halifax, Nova Scotia B3J 3J9, Canada g \\ 3. Leptis E\&P Ltd., Watford, Hertfordshire WD17 4QX, \\ United Kingdom
}

This presentation reviews recent evidence for the presence of working petroleum systems on the deepwater Scotian Slope, offshore Nova Scotia. It uses data from recent pistoncoring cruises and from wells drilled offshore Morocco to speculate on what the age and type of source rock(s) could be present. The Scotian Slope extends from the shelf break at $200 \mathrm{~m}$ to almost $4000 \mathrm{~m}$ water depth. It is $850 \mathrm{~km}$ long with an area of about $80000 \mathrm{~km}^{2}$. Only eleven wells were drilled on the slope between 1983-2004 with little success to date other than minor gas discoveries in Annapolis G-24 (2002) and Newburn H-23 (2002). Geochemical analyses of selected cuttings samples from intervals in all wells where oil-staining was suggested failed to confirm the presence of migrated hydrocarbons because of the very high concentration of synthetic oil-based drilling mud.

Several direct hydrocarbon indications based on satellite observations and seismic analysis have been observed on the Scotian Slope. A regional geochemical survey with piston coring was undertaken by TDI-Brooks in 2000 that suggested thermogenic hydrocarbons may be present at some locations, although there are doubts whether they represented evidence of petrogenic hydrocarbons. In 2015 and 2016, the Nova Scotia Department of Energy, in partnership with the Geological Survey of Canada, organized piston-coring cruises on the Scotian Slope to confirm the presence of seeps suggested by satellite and seismic evidence. The 2016 cruise encountered gas hydrates for the first time at three separate sites. At two of these locations, the methane in the hydrate had a biogenic origin but the third site had a thermogenic oil-associated gas based both on its composition and isotopes. Sediment samples from this site also show strong evidence for petrogenic hydrocarbons. This site provides good evidence for a working petroleum system and oil-prone source rock in this area. Indications of thermogenic gas and/or sediments with possible petrogenic hydrocarbons were also observed at other sites along the Scotian Slope, implying one or more source rocks with wide areal extent. Nova Scotia's conjugate margin is offshore Morocco. Here, oil has been found in Upper and Middle Jurassic reservoirs that might be equivalent to those that could occur on the Scotian Slope. Oils from these reservoirs have different geochemical characteristics suggesting at least two different Jurassic carbonate source rocks.

Sand supply to the Slyne Basin, offshore western Ireland - insights into Triassic palaeogeography of the Northeast Atlantic margin

\section{Jess Franklin ${ }^{1}$, Shane Tyrrell ${ }^{1}$, Andrew Morton $^{2}$, AND CHRIS MARK ${ }^{3}$}

\section{Earth and Ocean Sciences, Sediment Origins Research \\ Team (SORT) and Irish Centre for Research in Applied Geosciences (iCRAG), National University of Ireland, University Road, Galway, Ireland $\mathbf{g}$ \\ 2. HM Research Associates and CASP, University of \\ Cambridge, Cambridge, Cambridgeshire, United Kingdom $\mathbf{g}$ \\ 3. Department of Geology and Irish Centre for Research in Applied Geosciences (iCRAG), Trinity College, College Green, Dublin 2, Ireland}

During the Triassic, present-day Northeast Atlantic margin basins lay within the Laurasian region of the Pangean supercontinent, approximately $15-20^{\circ}$ north of the equator. Ongoing investigations of Permian-Triassic basins along the Northeast Atlantic margin aim to better understand large-scale drainage patterns throughout the Mesozoic, to better predict sand distribution across these basins, and to potentially identify links between basins on the Atlantic conjugate margins. Sediment transport on the Irish Atlantic Margin during the Triassic remains relatively elusive. Sediment dispersal systems supplying these basins are thought to be independent of those which fed UK basins.

This study is focussed on the Slyne Basin, which is located $(\sim 60 \mathrm{~km})$ west of Ireland. A multi-proxy methodology is being employed to ensure rigorous provenance analysis. U$\mathrm{Pb}$ geochronology of robust zircon and relatively unstable apatite and $\mathrm{Pb}$ isotopic analysis of labile $\mathrm{K}$-feldspar are being utilised to identify and constrain the relative contribution from possible source areas. This approach aims at reducing the potential bias in each individual method, producing a complimentary dataset which may also help in the identification of any recycling or mixing of detritus.

Results from the $\mathrm{Pb}$ isotopic analysis of $\mathrm{K}$-feldspars reveals mixed Archaean-Proterozoic sources. These results suggest sources such as the Lewisian Complex of northwest Scotland, the Nagsuggtoqidian of eastern Greenland, and the Rhinns Complex and offshore basement highs such as the Rockall and Hatton Banks, and the Porcupine High. Sources from onshore Ireland identified through feldspar analysis include the Annagh Gneiss Complex, a series of Palaeo-Neoproterozoic orthogneisses in western Ireland, 
and Caledonian Granites. U-Pb ages of apatite and zircon grains are consistent with the sources identified by the $\mathrm{Pb}$ isotopic analysis of K-feldspar; however, a Permian population, with no clear equivalent $\mathrm{K}$-feldspar, has also been detected.

These results support the hypothesis of a drainage divide between the basins offshore western Ireland versus onshore UK and eastern Ireland, possibly due to an uplifted Irish Massif which was not itself a major supplier of sediment. Sand supply was dominantly from the north with significant input from the eastern and western flanks of the basin, with previously unrecognised sources, such as Permian rocks, playing an important role. Potential Permian sources include volcanic rocks in the Midland Valley of Scotland, the Ulster Basin, and the Shetland Platform.

New insights on prospectivity of the eastern Orphan Basin, offshore Newfoundland and Labrador, Canada

\section{Erin Gillis, Richard Wright, David McCallum, Leona Stead, and Victoria Mitchell}

\section{Nalcor Energy Limited, 45 Hebron Way, St. John's, Newfoundland and Labrador A1A 0P9, Canada}

The Orphan Basin is a large Mesozoic basin located off the east coast of Newfoundland, Canada. Since 2011 it has seen a resurgence of data acquisition and new geologic insights on the potential petroleum systems within. Starting in 2011, TGS/PGS have undertaken a large scale multi-client 2D seismic program on the eastern margin of Newfoundland and Labrador. This program has now collected over 170000 line kilometres of modern long-offset broadband 2D data across the margin. The majority of the Orphan Basin has been imaged with a $5 \mathrm{~km}$ by $5 \mathrm{~km}$ seismic grid. In addition, two large 3D seismic surveys were also acquired in the region. These large-scale data programs have led to many new insights to the geology of the basin and its potential petroleum systems.

Within the eastern Orphan Basin, the area of the 9800 $\mathrm{km}^{2} 2017$ 3D seismic survey was initially mapped with the modern 2D $5 \mathrm{~km}$ by $5 \mathrm{~km}$ seismic grid. This initial mapping with the 2D seismic was able to provide a detailed regional stratigraphic framework of the basin, as well as preliminary mapping of prospective hydrocarbon leads within the area. The 2017 3D seismic survey has provided material uplift in imaging of the Mesozoic allowing for the resolution of complex structural/stratigraphic leads, as well as the broader petroleum system. Prospectivity within the East Orphan Basin is not confined to one play type. Rather, multiple play concepts are mapped with AVO supported leads throughout the Jurassic, Cretaceous and Cenozoic sections.
Underpinning the East Orphan Basin is a thick succession of Jurassic and Cretaceous sediments that may act as potential source for the area. Recent heat-flow data collected shows a systematic variance over the 2017 3D seismic area, and these variations in heat flow will be a major factor in which potential source intervals are in the maturity window over the basin. Co-located with the 2017 3D seismic survey is a multi-beam and shallow seabed coring project that was acquired by Fugro in the 2017 season. Shallow cores were collected to sample for geochemical evidence of an active petroleum system in the area. Analysis of this seabed coring data has been integrated into the petroleum system evaluation of the area and is giving further insight into the prospectivity of the East Orphan Basin.

Sergipe-Alagoas Basin, eastern Brazilian margin oblique rifting with an igneous overprint

\section{Joseph K. Goode, Andre Belopolsky, Tim Grow, And Paul Whitehouse}

\section{Hess Corporation, 1501 McKinney Street, Houston, Texas 77010, USA}

The Sergipe-Alagoas Basin lies on Brazil's eastern margin between the Ascension Fracture Zone to the north and the Bo de Verde Fracture Zone to the south. Oblique opening of the South Atlantic Ocean separated the Sergipe-Alagoas Basin from its conjugate, the Gabon Basin. The deepwater Sergipe-Alagoas Basin is an emerging province for hydrocarbon exploration and an excellent example of oblique rifting with an igneous overprint. High quality $2 \mathrm{D}$ and $3 \mathrm{D}$ reflection seismic data, and potential fields measurements reveal the tectonic domains comprising the basin and the development stages of today's passive margin basin. The history of basin development that emerges is: (1) Berriasian through Barremian distributed rifting of continental crust; (2) Progressively focused continental extension; (3) Emplacement of SDRs; (4) Aptian continental breakup; (5) Localized Albian source rock deposition; (6) Albian hotspot volcanism near the edge of the continent; (7) Regional Cenomanian source rock deposition; (8) Hotspot migration across proximal oceanic crust through the Campanian; (9) Upper Cretaceous turbidite sandstone deposition; (10) Tertiary deep water deposition continuation from the Sao Francisco River; and (11) Migration of hotspot volcanism to outboard of the sedimentary basin by the Paleocene. 


\section{The role of inherited thermal and lithospheric heterogeneities in rifting and continental breakup}

\section{Mohamed Gouiza², John NalibofF², And Douglas, A. PATON $^{3}$ \\ 1. University of Leeds, School of Earth and Environment, Leeds, West Yorkshire LS2 9JT, United Kingdom 9 \\ 2. University of California-Davis, Earth \& Planetary Sciences \\ Department, One Shields Avenue, Davis, California 95616, USA 9 \\ 3. University of Leeds, School of Earth and Environment, Leeds LS2 9JT, United Kingdom}

Many Atlantic margins exhibit major along-strike variations in the rift geometries, crustal architectures and magmatic budgets associated with continental breakup (i.e. conjugate margins of South Africa/Argentina, Morocco/ Nova Scotia, Labrador/Greenland). Variations in these rift characteristics often seem to develop during the same rifting event and over short distances.

Recent work on the Labrador margin, for instance, suggests that the northern segment is characterized by a lack of synrift structures and a magma-rich breakup with seaward dipping reflections (SDR) documented in the continentocean transition domain (COT). In contrast, the southern segment shows major synrift structures that accommodated continental stretching, a wide hyperextended crustal domain, and a magma-poor breakup with a wide domain of exhumed serpentinized mantle in the COT. We attributed this contrasting evolution within the same oceanic basin to Archean-Proterozoic inheritance, which shaped the preMesozoic lithospheric structure.

The initial lithospheric structure in the south was characterized by thicker crust and a hot depleted subcontinental mantle, whereas the north contained a thinner crust and a cooler primitive subcontinental mantle. This heterogeneous prerift structure occurred across two major Precambrian structural zones that can be traced onshore through the Canadian Shield and SW Greenland. We propose that southward thickening of the prerift crust likely produced a corresponding thickening of the ductile middle crust, which promoted delayed vertical coupling, hyperextension, and a wide domain of exhumed serpentinized mantle. In contrast, a significantly thinner ductile middle crust in the north may have led to the quick formation of lithosphericscale detachment faults that limited the amount of stretching, hyperextension and mantle exhumation and serpentinization.

Here, we will use thermo-mechanical modelling to investigate these hypotheses and examine the role of structural inheritance on rifting processes. Using constraints from the Labrador Sea, we specifically plan to examine the interplay between heat flow, radiogenic heat distribution, crust and lithosphere thickness, rheology and mantle composition during continental stretching and breakup.

\section{Deepwater exploration along the West Africa Transform Margin: a retrospective and an outlook}

\author{
Colin Grant, Sanjoy Ghosh, Phil Thompson, Rob \\ StAples, And Afra Antonini \\ Exploration Portfolio and New Business, \\ Shell International Ltd., Level 25, 40 Bank Street, \\ Canary Wharf, London E14 5NR London
}

Since the year 2000, the equatorial West Africa Transform Margin (WATM) has received considerable investment in deepwater exploration activity through multi-client seismic campaigns, geological and geophysical studies, and the drilling of 74 exploration wells. This investment resulted in more resounding failures than commercial successes. Only within a small segment of the Tano Basin of West Ghana and nearby off-shelf drilling in the Cote D'Ivoire has exploration delivered multiple oil and gas discoveries that have gone on to become development projects and potential commercial successes (e.g., Baobab, TEN Fields, and Jubilee). Within the other basin segments that make up this region of oblique Cretaceous rifting, moveable hydrocarbons were found, but low discovered volumes, effective reservoir problems, as well as a low-oil price environment, have deterred recent investment.

Before attempting to predict the future trend of exploration along this margin, a brief retrospective on deepwater exploration drilling is provided. We focus on three prominent basin segments: Benin, Cote D'Ivoire, and Sierra Leone, looking at exploration results, including those of Shell's Houmelan-1 well in Benin, and summarizing what these tell us about the Atlantic margin petroleum systems and the deepwater plays they targeted.

To justify future exploration investment in a complex tectonostratigraphic setting that has historically delivered mostly limited technical success, explorers, engineers and economists need to provide concrete answers to three fundamental questions: (1) What do we need to find downhole to have the best chance of delivering a healthy full lifecycle, free cash-flow positive development project in a variable oil price environment? (2) Which under-explored parts of the Equatorial African-margin have the right geology for this? (3) On what plays should the industry focus near-term activity to have the highest chance of success?

This paper concludes by looking to the future. In doing so, it concentrates on potential remaining rewards rather than dwelling on the risk that future exploration investment along this margin destroys corporate value. Against the latter challenge our industry needs to maintain its optimism, retain its credibility, and continue to strive to deliver the hydrocarbon molecules needed to help the economies of West Africa prosper. 


\section{Building a geological pressure model using global analogues}

\section{Sam Green and Alexander P. Edwards}

\section{Ikon Science, 1 The Crescent, Surbiton, Surrey KT6 4BN, United Kingdom}

There are many different elements to a play requiring analogues to aid in de-risking. Analogues are often focused on a similar basin-scale tectonostratigraphic framework but there are many aspects to a geological pressure model that must be de-risked, for example, sand-shale geometries, reservoir plumbing, TOC within shales, thermal evolution, and sedimentation rate. There are many examples of analogous processes and relationships that can de-risk the pore pressure from settings that would not be considered analogous if only based on the basin-scale framework. There are several examples of analogous pairs of basins where one is more heavily drilled, and thus provides a rich database, and the other has minimal-to-no wells, yet shows significant potential for exploration. One such pair would be the deepwater areas of Middle Norway (data-rich) and Labrador (data-poor) where the tectonostratigraphic framework is very similar on both sides of the Atlantic Margin. Other examples from French Guiana, Guyana, and Suriname include the Zaedyus, Jaguar, and Liza discoveries based on experience in West Africa.

Constructing a pore pressure profile in deepwater plays involves several stages. Firstly, the lithofacies must be understood, partly from seismic reflectivity data and partly from analogue settings. Secondly, reservoirs often have different pressures to their associated shales; they can be lower via lateral drainage or higher due to lateral transfer. Thirdly, modelling of shale pore pressure in frontier locations is often undertaken using seismic interval velocities, often the only data type available, yet these data may not be suitable if the shales have undergone diagenesis. A frequent problem in wildcat situations, with little to no well calibration, is the reliance on seismic interval velocities for pressure prediction. Lastly, pore pressure is assumed to be generated via vertical loading by sediment and undercompaction of shales; in reality, other processes such as fluid expansion and load transfer can increase the pore pressure beyond that predicted by standard techniques.

This presentation aims to show how the integration of global analogues can aid in building a pore pressure profile; de-risking the magnitude of the pore pressures that are predicted; and provide confidence in the sub-surface facies model that helps define the pore pressure model. Generation of a pressure profile requires that all elements discussed above must be considered.

\section{Reservoir quality controls in synrift facies of North Atlantic margin basins, offshore Newfoundland, Canada, and southwestern Ireland}

\section{Simon F. Greenfield And Anne McAfee}

\section{Core Laboratories Integrated Reservoir Solutions, Redhill, Surrey RH1 2LW, United Kingdom}

The varied success of exploration campaigns targeting Late Jurassic-Early Cretaceous sandstones in North Atlantic Margin basins prompts fundamental questions regarding the key controls on reservoir development and reservoir quality in this complex tectonic domain. Our approach to reservoir evaluation is to perform systematic rock-based sedimentology and detailed petrography of the full drilled succession in representative wells from all drilled basins. Our rock database for these North Atlantic basins includes 91 offshore wells from which we generated $>2200 \mathrm{~m}$ of new core description and $>700$ new core and cuttings thin section analyses. The main conclusion of our studies in this region is that the structural architecture exerted strong influence on both facies composition and cementation trends throughout the Oxfordian to Albian evolution of the margin.

In the Porcupine Basin, delta top channel and shoreline sandstones are preserved in the highly faulted Connemara Field area, where grain size, sorting, and clay volumes are the main controls on reservoir quality. Farther east in the Spanish Point Field, fluvial and fan delta feeder systems discharged directly into a fault-bounded topographic low, leading to the preservation of thick massive/fluidized coarsegrained delta front turbidite deposits. Here, the sandstones are both compositionally and texturally immature and show strong compaction and relatively strong cementation by carbonate minerals.

The Late Jurassic succession in the Flemish Pass Basin is characterized by sharp-based, fluvial-dominated sand packages encased within mid to outer shelf mudstones. These Tithonian sandstones show variable cementation and hydrocarbon charge in adjacent wells, thought to be due to the circulation of fluids around venting faults. The Lower Cretaceous succession in the Jeanne d'Arc Basin is dominated by lower delta plain and shoreline facies, including thick packages of burrowed, fossiliferous shoreface sandstones (e.g., Ben Nevis Field). In these sediments, the main controls on reservoir quality are grain size, bioturbation type and intensity, burial depth and volume of carbonate cement.

Several genetically related late diagenetic features occur in both Upper Jurassic and Lower Cretaceous reservoir units. These features include fracture-associated sulfide mineralization and secondary porosity development, possibly related to Albian magmatic activity. 


\section{The results of a major source rocks and oils study of the North Atlantic conjugate margin with a focus on offshore Ireland}

\section{Michael Hanrahan ${ }^{1}$, Kara English ${ }^{1}$, James P. ArMSTRONG $^{2}$, AND IAN ATKINSON ${ }^{3}$ \\ 1. Petroleum Affairs Division (PAD), Department of \\ Communications, Climate Action and Environment, 29-31 Adelaide Road, Dublin 2, D02 X285, Ireland g \\ 2. Petroleum Systems Limited, 30 Linden Walk, Prestatyn LL19 9EB, Wales, United Kingdom g \\ 3. Nalcor Energy Limited, 45 Hebron Way, St. John's, Newfoundland and Labrador A1A 0P9, Canada}

A comprehensive review of source rocks and oils from basins offshore Ireland was carried out as part of a major study to further understand the development and distribution of source rock facies and their resultant hydrocarbon products between basins, and, across the conjugate margin with Canada. The study included well data from all offshore Irish basins. The database from offshore Ireland includes source rock chemical analyses from 153 wells and analyses of 38 oil samples supplemented by source rock extract analyses.

The interpretation of these data indicates that some 15 different source rock horizons exist in the Irish basins within Mesozoic and Early Tertiary sediments. Oils in the Rockall Basin demonstrate a close affinity to oils in the North Sea and West Shetland due to the presence of 28, 30 bisnorhopane sourced from the Upper Jurassic Kimmeridge Clay Formation, suggesting a possible palaeoenvironmental link at this time. Additionally, the Jurassic is an important proven source rock in the Slyne Basin where the Lower Jurassic is in the oil window. The Middle and Upper Jurassic were identified as the primary source of the oils found in the Porcupine Basin and all these oils display also a typical character of gammacerane that suggests a long-standing stratification of the water column within the basin. The Celtic Sea basins demonstrate Jurassic and Lower Cretaceous source rocks ranging from marine to lacustrine organofacies resulting in two main families.

The Irish oil samples were compared to oil samples from the Flemish Pass and Jeanne d'Arc basins of Newfoundland and Labrador, which demonstrated that various source rock facies across the conjugate margin can be related to one another and grouped into families. We propose several "Super Families" of oils, including the regionally significant Upper Jurassic, highlighting numerous geochemical similarities attributed to analogous source facies across these basins.

This study is underpinned by possibly the most comprehensive oil and source rock dataset accumulated for the Canadian-Irish conjugate North Atlantic basins. From this, it is possible to directly compare the oils and also the parent source rock facies within and between each basin. This is especially important in the under-explored portions of some basins (e.g., the southern Porcupine Basin) where there is a lack of well data. In conclusion, the results of the study have positive implications for petroleum prospectivity in basins offshore Ireland as well as other basins within the greater study area.

\section{Seismic and lithological characterization and source rock potential of the Aptian Naskapi Shale Member, Logan Canyon Formation, offshore Nova Scotia, Canada}

Anne C. Hargreaves, F. W. Richards, Ricardo L. Silva, AND GRANT D. WACH

Basin and Reservoir Lab, Department of Earth Sciences, Dalhousie University, Life Sciences Centre, Halifax, Nova Scotia B3H 4R2, Canada

The Early Cretaceous fluvial-deltaic successions of the Logan Canyon and Missisauga formations, offshore Nova Scotia, have produced hydrocarbons in the Sable subbasin. Distal deposits of the Jurassic-Cretaceous Verrill Canyon (Bajocian - Barremian) and the Logan Canyon (Aptian - Albian) contain transgressive shale sequences, several of which correspond to worldwide oceanic anoxic events (OAEs). A significant one is the Aptian Naskapi Shale Member, the basal unit of the Logan Canyon Formation, and the focus of this study.

The Jurassic shale section has been viewed as a relatively lean source rock; however, it is disputed if there are sufficient total organic carbon (TOC) or vitrinite reflectance (VR) values to generate hydrocarbons or form a fluid phase sufficient to facilitate migration. The Naskapi Shale Member does not appear to exhibit significant levels of organic matter, nor share characteristics from contemporaneous oceanic anoxic events seen elsewhere in the world. Our study suggests this was due to: (1) a high delta-derived sediment load focused in the Sable Sub-basin during the Cretaceous that resulted in high dilution rates; and (2) the ocean current regime during that time was not optimal for high production and deposition of organic matter.

Examination of datasets from 95 wells on the Scotian Shelf incorporating heat flow, total organic carbon, X-ray fluorescence, wireline log data from gamma ray, sonic, density and neutron logs, lithological descriptions from cuttings and core, biostratigraphy, sedimentation rates, paleo-ocean currents, and seismic interpretations of the Naskapi Member permit creation of an extensive suite of isochore maps and 3D models. These maps portray and define the stratigraphy, sedimentology, and diagenesis associated with the Naskapi succession. 
Comparison of the Scotian Margin with time equivalent Cretaceous deposits elsewhere on the Atlantic Margin suggests that the low levels of effective Cretaceous source rocks here are due to paleo-ocean currents and high volumes of sediments shed from the adjacent Appalachian Mountains.

Palaeogeography, palaeo-earth systems, and the predictive modelling of source rock environments in Atlantic margin basins

\author{
James (Jim) P. Harris ${ }^{1}$, Simone Agostini ${ }^{1}$, Peter \\ Allison $^{2}$, Alexandra Ashley ${ }^{1}$, Rob Crossley ${ }^{1}$, \\ Mike Goodrich ${ }^{1}$, Simon OtTo ${ }^{1}$, Paul Valdes ${ }^{3}$, AND \\ JOHNWATSON $^{1}$
}

\section{CGG Services (UK) Ltd., Maelgwn House, Parc Caer Seion, Conwy, Llandudno North Wales LL32 8FA, United Kingdom g \\ 2. Imperial College London, South Kensington Campus, London SW7 2AZ, United Kingdom g \\ 3. School of Geographic Sciences, University of Bristol, University Road, Clifton, Bristol BS8 1SS, United Kingdom}

The breakup history of the Atlantic margin basins was accompanied by wholesale variations in palaeoclimate that represent the main controls on stratigraphy and resource potential. Given this complex regional geohistory, the distribution of source rocks and the lateral variation in source quality are significant difficulties for exploration. To construct a predictive tool designed to address this problem, deformable plate kinematics reconstructions were used as the basis for palaeogeographic mapping. Detailed gross depositional environment maps were prepared using a database of stratigraphic, seismic, palaeoenvironmental, lithofacies, and source rock data compiled from a legacy data resource representing over 35 years of petroleum geological studies and the public domain.

A novel method relating topography and bathymetry to plate tectonic environments was used in the construction of paleo-digital elevation models (DEMs). The DEMs were coupled with state-of-the-art paleo-earth systems models (UK Met Office HadCM3 palaeoclimate model) and an unstructured mesh model to simulate palaeotides (Imperial College, UK, ICOM tide model). The database also includes climate proxies used to test the veracity of the modelling results. This approach provides an understanding of regional paleogeographic and paleoclimatic geohistory that includes drainage basin evolution and the quantification of clastic sediment flux.

In conjunction with the DEMs, paleo-earth systems were used to create a new predictive model of organic matter productivity, accumulation, dilution, and preservation that defines source facies depositional space for a broad range of marine source rock environments developed during the breakup history of the Atlantic margin. The gridded model results also provide an objective assessment of lateral variability in source quality for key source rock horizons.

\section{Early Jurassic Earth System and Timescale project (JET): towards an integrated stratigraphy for the Early Jurassic based on the Mochras borehole, Cardigan Bay, Wales}

\section{Stephen P. Hesselbo and the JeT Project Science Team}

\section{University of Exeter, Camborne School of Mines, Penryn Campus, Penryn, Cornwall TR10 9FE, United Kingdom}

During the Early Jurassic, the planet was subject to distinctive tectonic, magmatic, and orbital forcing, and fundamental aspects of the modern biosphere were becoming established in the aftermath of the end-Permian and end-Triassic mass extinctions. The breakup of Pangaea was accompanied by biogeochemical disturbances including the largest magnitude perturbation of the carbon-cycle in the last $200 \mathrm{Ma}$, the Toarcian Oceanic Anoxic Event (T-OAE). Knowledge of the Early Jurassic is, however, based on scattered and discontinuous datasets, meaning that stratigraphic correlation errors confound attempts to infer temporal trends and causal relationships, leaving us without a quantitative process-based understanding of overall Early Jurassic Earth system dynamics.

The Llanbedr (Mochras Farm) borehole in west Wales, originally drilled 50 years ago, provides the basis for construction of an integrated biostratigraphic, magnetostratigraphic, chemostratigraphic, and astrochronological timescale for the entire Early Jurassic. At Mochras, the drillcore represents $27 \mathrm{Ma}$ of Early Jurassic time with a calculated sedimentation rate of approximately $5 \mathrm{~cm} /$ $\mathrm{ka}$. The Integrated Early Jurassic Timescale and Earth System project (JET) is a multi-faceted, international programme of research on the functioning of the Earth system. New data from the old Mochras core will be combined with data from a new core to provide an understanding of global change and quantify the roles of tectonic, palaeoceanographic, and astronomical forcing on hyperthermal and hypothermal events at this key juncture in Earth history. Analysis of this record will also be used to understand the functioning of the Laurasian Seaway, its effects on climate and depositional patterns, including the distribution and nature of organicrich black shales (potential hydrocarbon source rocks).

Initial results define a continuous integrated astrochronological timescale for the Pliensbachian and Toarcian stages, and through the principal hyperthermal 
interval document significant changes in background sedimentation style (related to eustatic sea-level rise) and local sediment input driven by climate change in the adjacent source areas. We acknowledge funding from Shell, the International Continental Scientific Drilling Programme (ICDP), the UK Natural Environment Research Council (NERC), and the Deutsche Forschungsgemeinschaft (DFG).

Untested plays in deepwater Nova Scotia, Canada analogs to successes along the circum-Atlantic margin

Randolph G. Hiscock ${ }^{1}$ ANd Adam MacDonald ${ }^{2}$

\section{Avalon Upstream Ltd., St. John's, Newfoundland and Labrador A1M 3M4, Canada g \\ 2. Nova Scotia Department of Energy-Petroleum Resources, Halifax, Nova Scotia B3J 3P7, Canada}

Nova Scotia's deepwater margin remains a high potential, untapped, frontier oil and gas province. All the necessary prerequisites for a major petroleum basin are present, with only 13 wells drilled in water depths greater than 1000 m. Despite Shell's recent lack of success in the Shelburne Sub-basin, multiple plays successful elsewhere along the conjugate circum-Atlantic margin are evident. A tenyear analysis of Cretaceous fans demonstrate that play sweet spots exist in the slope setting dominated by normal faulting with more gentle gradient margins. Similar to the West African and South American deepwater basins that experienced multiple tests prior to success, Nova Scotia’s deepwater basins exhibit a diversity of drilling prospects from differing play domains. T urbidite pinch-outs, subsalt synrift, and ponded turbidites behind salt diapirs are examples of untested prospects along with pre-salt potential that are evident from existing $2 \mathrm{D}$ seismic.

\section{Seismic expression of mantle convection to model Atlantic passive margin phenomena}

\section{Neil Hodgson and Karyna Rodriguez}

\author{
Spectrum Geo Dukes Court, Duke Street, Woking, Surrey, GU21 \\ 7RJ, United Kingdom
}

As the acquisition of modern, long offset and long record length 2D seismic data increases, so to are revelations of the key physical characteristics of passive margins: (1) Continental-Oceanic transition: abrupt continental margins to hyper-extended margins; (2) Magmatism: magma rich both clastic rich and clastic poor Seaward Dipping Reflector (SDR) rich to magma poor margins; and (3) Asymmetry: margins with wide synrift remnants (salt rich or salt free) to margins apparently devoid or with narrow synrift remnants. Each of these endmember series displays localized variation on the basin and margin scale and indeed some are observed as part of continuums others are binary distributions.

A review of a number of 2D seismic lines from Atlantic passive margins, extending from the continental section out over oceanic crust, allow us to compare and contrast the influence of these key characteristics on each margin, and observe the degree of variation between them. For each characteristic, a model will be presented offering explanations for why that characteristic endmember, and continuum set if appropriate, has developed.

Abrupt continental margins have narrow zones of transition separating oceanic crust from thick $(>30 \mathrm{~km})$ continental crust, whereas hyper-extended margins display fragments of extension and shear-thinned continental crust drawn out far from the shelf. We propose a model where variation in abruptness of a margin along-rift relates to variation in heat from mantle during rifting.

Magma-rich margins display wide zones of SDRs comprising largely flood basalts but varying from clasticrich to clastic-poor outboard. Magma-poor margins apparently display no flood basalts and the final continental crust fragments either transition into oceanic crust directly, or, exhumed mantle and then oceanic crust. Although the amount of subaerial and submarine magmatism is clearly a function of relative sea level, we propose a model for undulations along-rift in a synrift setting.

Conjugate margins are often somewhat dissimilar, or asymmetric. The amount of synrift section above thinned continental crust remaining post-drift varies significantly, and we propose a model explaining observed asymmetry and variations in this characteristic. To conclude, we introduce a simple model that seeks to provide a mechanism for both the formation of the key structural characteristics on passive margins and the observed variation in these characteristics. 


\section{D and 2D petroleum system modelling of potential Lower Jurassic source rock on the Scotian Margin, offshore Nova Scotia, Canada}

\section{Xinyue Hu${ }^{1}$, Juan C. Wong, Ricardo L. Silva, and Grant D. WaCh}

Basin and Reservoir Lab, Department of Earth Sciences, Dalhousie University, Life Sciences Centre, Halifax, Nova Scotia B3H 4R2, Canada

The Scotian Basin is a passive margin with an area of approximately $280000 \mathrm{~km}^{2}$. Five potential Mesozoic source rocks intervals (Aptian, Valanginian, Tithonian, Callovian and Early Jurassic) have been identified in the Scotian Basin. However, the Early Jurassic source interval has never been penetrated by drilling and is inferred from the Moroccan and Portuguese conjugate margins. The characteristics of the Lower Jurassic source rock have large uncertainty. Building $1 \mathrm{D}$ and 2D models can reduce these uncertainties and lower the risk in hydrocarbon exploration.

In this study, $281 \mathrm{D}$ models and four 2D models were created and analyzed in PetroMod ${ }^{\mathrm{m}}$ (Schlumberger). Compared to previous models of the petroleum systems for the Scotian Margin, our 1D models have greater lithostratigraphic resolution and these results are incorporated into the formulation of the $2 \mathrm{D}$ models not previously completed along the margin. The high resolution of lithostratigraphy is based on the extensive well cuttings database provided by Canadian Stratigraphic Services and correlated with seismic and well data. The 1D models show the impact of salt structures on thermal maturity. The wells within salt diapiric area of the central Scotian Margin have higher temperature and higher source rock maturity.

The 2D models are based on dip lines of the ION NovaSPAN $^{\mathrm{m}}$ geophysical dataset (NVR1-5100, NVR15400, NVR1-5420, and NVR1-5300). Variable source rock properties (Hydrogen Index and Total Organic Carbon) were incorporated reflecting $t$ he $\mathrm{p}$ otential $\mathrm{r}$ ange $\mathrm{t}$ hat may be encountered during deposition and subsequent maturation of organic-rich intervals along the Scotian margin. The transformation ratio is related to the Hydrogen Index (HI) number with higher numbers giving to a higher transformation ratio, and the potential for the formulation of oil. These source rock properties are based on the data from the High and Middle Atlas basins of Morocco. Our results suggest the potential Lower Jurassic source rocks have different ranges of maturity in the Scotian Basin and are within the oil window in the north and transition to the gas window in the south.

\section{Petroleum systems analysis of the United States Atlantic margin}

\author{
Daniel Kay, Jan Major, James (Jim) P. Harris, Alex \\ Ashley, John Watson, and Simone Agostini
}

\section{CGG Robertson, Tyn-y-Coed, Pentywyn Road, Llandudno, Wales LL30 1SA, United Kingdom}

With the possible reversal of restrictions on hydrocarbon exploration and production activity on the US Atlantic Seaboard, we look at which basins and plays have the greatest potential. The US Atlantic Continental Shelf extends for over $2000 \mathrm{~km}$, and although over 50 exploration wells have been drilled in the area only minor gas and condensate discoveries have been made with exploratory drilling ceasing in the middle 1980s. The potential of the basins is therefore largely unknown.

The four prospective basins, Georges Bank, Baltimore Canyon, Carolina Trough and Blake Plateau extend from New England in the north to Florida in the south. Petroleum plays range from the Middle Jurassic to the Pliocene, and all are mixed carbonate and clastic systems. Each basin was assessed through detailed analysis of candidate source, reservoir, and seal horizons. The distribution, extent, and quality of each candidate horizon and likely trapping and charge mechanisms were assessed to estimate which basins hold the greatest exploration potential. The basins are underexplored and in many areas there is a lack of data; as a result a combination of predictive models and analogous data sets along with $1 \mathrm{D}$ thermal modelling were used to evaluate reservoir quality and source rock presence and maturity.

Multi-BCF fields and discoveries have been made in Canadian waters to the north (e.g., Scotian Basin's Venture, Thebaud, Deep Panuke fields, etc.) and significant discoveries have recently been made along the conjugate West African margin from Morocco to Senegal. The exploration success in these regions provides compelling indications that a working petroleum system could exist in the basins of the US Atlantic margin.

We conclude that Baltimore Canyon has the greatest potential of the four basins, which is in agreement with the 2012 BOEM report: "Assessment of Undiscovered Technically Recoverable Oil and Gas Resources of the Atlantic OCS". This shows broadly the same area (Mid Atlantic OCS) identified as having the greatest potential (4.87 BBOE). However, further observations from predictive mapping (MERLIN+) also show significant source potential in Triassic lacustrine rift basins analogous to the onshore Newark Supergroup basins. 


\section{Rifting and magmatism in cratonic lithosphere: the rifted margin off northern Labrador, Canada}

Charlotte E. Keen, Kate Dickie, and Lynn T. Dafoe

Natural Resources Canada, Geological Survey of Canada
(Atlantic), Dartmouth, Nova Scotia B2Y 5A2, Canada

High quality seismic reflection data from the offshore northern Labrador rifted margin allows imaging of the extended and rifted crust both along and across the continental margin. We describe these in conjunction with available seismic velocity and gravity data. The margin formed within cold, thick cratonic lithosphere. Both basement and a discrete, high-amplitude, deep reflection about $10 \mathrm{~km}$ below basement are observed. The deeper reflection can be correlated with the crust-mantle boundary as measured on previous wide-angle seismic data in the region, where the crust has been thinned to about $10 \mathrm{~km}$. This reflection, termed here the L-reflection, disappears where the crust is greater than about $14 \mathrm{~km}$ thick.

We suggest that the L-reflection is the equivalent to other top mantle detachments found elsewhere on magma-poor rifted margins, such as the S-reflector off Iberia. However, here the reflection occurs below thicker crust than elsewhere, possibly because of the occurrence of colder, more brittle crust. There is some evidence to support a zone of exhumed serpentinized mantle seaward of the thinned continental crust, including previous wide-angle seismic velocity results and the low reflectivity of basement in this zone. A gravity model across the margin is also consistent with this possibility, and it is supported by north-south correlations, linking the central Labrador margin where more data is available with this northern Labrador region.

A crustal cross-section across this margin and its conjugate off West Greenland at the end of rifting in Late Cretaceous/Paleocene time shows marked asymmetry, with a wider zone of crustal thinning on the Greenland side. This asymmetry is reversed to the south of the study region, as determined in previous studies. These crustal thinning profiles are comparable to those observed on other margins where the rift formed within cratonic lithosphere. While the attributes of this margin are mainly those of a magma-poor system, at the continent-ocean boundary, thick igneous crust creates a magma-rich zone in Paleocene time, when there was a hot spot in the Davis Strait to the north. Thus, this margin exhibits characteristics of both magma-rich and magma-poor systems.
The ocean-continent transition zone underlying the central Labrador margin, Canada

Charlotte E. Keen, Kate Dickie, and Lynn T. Dafoe
Natural Resources Canada, Geological Survey of Canada
(Atlantic), Dartmouth, Nova Scotia B2Y 5A2, Canada

The nature of the ocean-continent transition zone on the central Labrador rifted continental margin, and its conjugate off West Greenland, have been studied for several decades. Geophysical studies and deep drilling have increased our fundamental understanding of the tectonic evolution of this type of magma-poor margin globally.

Several elements of the ocean-continent transition zone have been delineated by a refraction survey during a previous experiment on the central Labrador margin, including a zone of extended continental crust under the shelf, a region underlain in part by exhumed and serpentinized mantle, and furthest seaward under the deepest part of the Labrador Sea, is oceanic crust. We show new 2D seismic data and link it to potential field data, and a deep seismic crustal velocity profile, with the results allowing us to: (1) extend the previously defined zones laterally for over $200 \mathrm{~km}$; (2) show that a zone of hyper-extended continental crust some tens of kilometres wide displays complex basement faulting with possible low-angle detachments and polyphase faulting; (3) define a transparent seismic character within the serpentinized basement zone; and (4) determine that the oldest oceanic crust is thin and structured with an age of about 70-65 Ma, similar to the 'proto-oceanic' domain defined on other margins. Therefore, seafloor spreading begins at about magnetic chron 31, earlier than the welldefined chron 27.

These results are compared to earlier studies of the West Greenland conjugate margin, and, other well-studied magma-poor margins. Given this rift occurred in thick, cold cratonic lithosphere, the results are remarkably similar to those rifts in Phanerozoic terrain off Iberia and Newfoundland, suggesting that a long rift history and/or mantle metasomatism may have weakened the cratonic lithosphere prior to the main rifting event. 


\section{Uranium/lead dating of lacustrine microbialites and other carbonates using LA-ICP-MS}

\section{David Keighley and Chris McFarlane}

\section{Department of Earth Sciences, University of New Brunswick, Fredericton, New Brunswick E3B 5A3, Canada}

Radiometric dating of carbonate deposits may constrain the timing of biogenic or physical-chemical crystallization, or subsequent post-depositional cements and fracture fill. In the first case, such dating has great potential in successions where biostratigraphic dating of the carbonate depositional environment is limited. An evolving technique utilizes Laser Ablation - Inductively Coupled Plasma - Mass Spectrometry (LA-ICP-MS) for U-Pb dating, an approach that has the advantages of high resolution, rapid data acquisition, and minimal sample destruction, which is important in cases where material availability is limited. However, carbonates, specifically calcites, are only datable if they have a viable $\mathrm{U}-\mathrm{Pb}$ ratio, for example, biogenic calcite is typically too low in $U$ to be suitable. Researchers are still identifying which carbonates offer the best opportunities for precise and reliable ages. Samples are pre-screened using micro$\mathrm{XRF}$ imaging to determine the presence of the metallic trace elements: screening also identifies clast and cement components with high $\mathrm{Mg}$ and $\mathrm{Fe}$, which regularly lead to poor results.

We are currently assessing the viability of radiometrically dating various carbonate clasts and cements from the Carboniferous strata of eastern Canada, and of stromatolites from the chronologically well-constrained upper part of the lacustrine Green River Formation (GRF) of Utah. Preliminary results of a GRF stromatolite from below the "Curly Tuff" $\left({ }^{40} \mathrm{Ar} /{ }^{39} \mathrm{Ar}\right.$ age of $\left.49.02+0.30 \mathrm{Ma}\right)$ give a promising result of $47 \mathrm{Ma}$, but so far with very high uncertainties that will necessitate further optimization of the ablation conditions.
3D seismic geomorphology of paralic channel complexes, Sable Sub-basin, offshore Nova Scotia, Canada

Trevor B. Kelly and Grant D. Wach

Department of Earth Sciences, Dalhousie University, Life Sciences Centre, Halifax, Nova Scotia B3H 4R2, Canada

Extensive fluvial systems drained expansive areas of present-day Canada throughout the Late Jurassic to Late Cretaceous and deposited over $12 \mathrm{~km}$ of sediment within the Scotian Basin, offshore Nova Scotia. In the Early Cretaceous Logan Canyon Formation and to a lesser extent, the underlying Missisauga Formation, these fluvial complexes are prominent and imaged in the ExxonMobil 3D seismic data cube known as the Sable Megamerge. The fundamental objective of this research is to observe the temporal and spatial fluvial system architectural variations, with an appraisal of the controlling features that are affecting this variability. This will be achieved by integrating sequence stratigraphy and seismic geomorphology within the 3000 $\mathrm{km}^{2}$ study area.

The seismic data cube was flattened on two surfaces representing the tops of the Logan Canyon and Missisauga formations. The process converts the seismic time slices into seismic horizon slices, showing sedimentary features in the depositional system. Seismic attributes are then applied to allow the fluvial systems and their associated architectural elements to become more distinct on the horizon slice images. These are combined with quantitative seismic geomorphology to obtain fluvial architecture parameters: channel width (CW), channel thickness (CT), meanderbelt width (MBW), radius of curvature (RC), meander wavelength (ML), channel length (CL), channel depth (CD), and sinuosity (SI). Well logs and conventional core 'ground truth' the seismic data. A qualitative analysis of fluvial systems in the study intervals defines the fluvial styles and the lateral spacing between channels. Characterizing these fluvial systems demonstrates: (1) the controlling factors and processes that lead to their formation; (2) the reservoir heterogeneity within the Sable Sub-basin; (3) the relative times for deposition of each stratigraphic sequence; and (4) it provides a catalogue of geometries and dimensions for the fluvial channel bodies in the study area within an overall deltaic depositional setting. 


\section{Correlating the Albian magmatic rift across the Sergipe-Alagoas and North Gabon conjugate margin: implications for source rocks above SDRs}

Alexander Kurobasa $^{1}$, Ian Davison ${ }^{1}$, and Helen Doran ${ }^{2}$

\author{
1. Earthmoves Limited, 38-42 Upper Park Road, Camberley, \\ Surrey GU15 2EF, United Kingdom g \\ 2. Ola Geoscience, 43 Lockview Road, Belfast BT9 5FJ, \\ United Kingdom
}

Deepwater exploration over the last few years in SergipeAlagoas and North Gabon has renewed our thinking of traditional models of the South Atlantic rift-to-drift transition, magma-poor and magma-rich end-members, and has furthered our knowledge of the role of magmatism on heat flow and subsidence in deepwater areas.

Seismic and well studies across the conjugate margins show the presence of three distinct phases of rifting; the Neocomian-Barremian rift system, episodic rifting in the Aptian corresponding to the linkage of isolated graben and shear zone systems, and the latest Albian magmatic rift that does not follow traditional breakup models for the opening of the South Atlantic. Many models use the Aptian base salt pick as a regional marker for end-rift and onset of thermal subsidence. However, this is not the case in the SergipeAlagoas and North Gabon conjugate, where rapid sag subsidence is not observed until the Cenomanian in the distal domain.

Deepwater wells in Gabon have penetrated the distal magmatic rift and found the lower sedimentary section to be composed of marine shales interbedded with sandstone stringers with a shallow marine affinity. The upper Albian section is composed of shale, marl, carbonate rocks, and volcanic rocks. Similar stratigraphy is encountered in the distal Sergipe-Alagoas Basin, and magmatism in the form of pillow basalt has been previously dated by ${ }^{40} \mathrm{Ar} /{ }^{39} \mathrm{Ar}$ at 104.8 \pm 2 Ma. Magmatism in the distal domain of both margins comprises a series of intrusions, SDRs, volcanoes and lava deltas.

Albian organic shales overlie the broad SDR domain and are considered to be the source of large oil discoveries in SergipeAlagoas (e.g., Moita Bonita and Barra). Recent deepwater wells in North Gabon have also documented good quality Albian source rocks deposited in a highly restricted shallow marine environment with volcanic input and fluctuating relative baseline changes. Deep penetrating seismic reflection data shows highly attenuated and infiltrated crust with a shallow 'Moho' reflector under the Albian rift system. Volcanic addition to the lower crust, in form of magmatic underplating, and in the upper crust as SDRs and intrusions in the distal domain allow the preservation of shallow water conditions necessary for the restricted source rocks and contrasting deeper water conditions in the proximal domain.

\section{How much salt is there in Ireland's Porcupine Basin?}

\section{Lucie Lamourette and Gregor Duval}

\section{CGG Services UK Ltd, Crompton Way, Manor Royal Estate, Crawley, West Sussex RH10 9QN, United Kingdom}

The presence or absence of salt in a basin can have dramatic consequences on petroleum systems. In general, evaporites are very good cap rocks and salt constitutes the top seal rock in many oil fields around the world. One type of evaporite, namely halite (sodium chloride / salt), deforms very easily under anisotropic stress-fields with flow-like characteristics. Halite deformation (halokinesis) and the induced deformations of the surrounding sediments provide a wide range of structures for trapping hydrocarbons. Furthermore, halite has a high thermal conductivity, so its presence and relative position (above or below) a potential source rock interval can have a significant effect on the hydrocarbon maturity window. Hence, knowing whether salt is present or absent at depth is an important factor in our understanding of petroleum systems.

In the Porcupine Basin, one well (namely 35/19-1) is known to have encountered salt. It penetrated about $150 \mathrm{~m}$ of halite encased in Kimmeridgian-Tithonian claystone. When looking at the seismic section intersecting the well trajectory, it is difficult to conclude if the salt is autochthonous, or, allochthonous. It might have been extruded from deeper and older sedimentary layers (thus interpreted as allochthonous salt) since the well was drilled through a visible fault on the seismic data. However, in favour of the autochthonous salt deposition, paleo-reconstruction of the Porcupine Basin's depositional environment indicates negative annual mean values of precipitation-evaporation rates and very high sea surface salinity during the Tithonian.

Not far north of the Porcupine Basin, well 18/25-1 in the Slyne Basin drilled through over $100 \mathrm{~m}$ of lagoonal anhydrite in the Lower Jurassic Hettangian series and about $50 \mathrm{~m}$ of halite in the Upper Triassic Rhaetian series. The presence of Rhaetian salt is proven on the conjugate Canadian Atlantic Margin, with the Argo Formation deposited in rift basins on the Scotian Shelf and Grand Banks. In the South Porcupine Basin, new 3D seismic data tentatively show evidence for the presence of salt in the Lower Jurassic-Upper Triassic section in the form of localized diapiric shapes. However, they are difficult to differentiate from structures possibly formed by tectonic inversion, and heavily rotated Jurassic fault blocks detaching on sub-horizontal listric fault planes.

This poster illustrates a number of issues based on the models and observations that we have described above and opens the floor for further studies (such as investigating and modelling seismic velocities) to better understand the distribution and age of salt in the Porcupine Basin. 


\section{Detailed structure of a magma-poor continent-ocean transition offshore northeastern Nova Scotia, Canada based on an along-strike wide-angle seismic profile (OCTOPUS)}

\section{K. W. Helen Lau ${ }^{1}$, Mladen R, Nedimović ${ }^{1}$, and Keith E. LOUDEN ${ }^{1}$}

Department of Earth Sciences, Dalhousie University, Life Sciences Centre, Halifax, Nova Scotia B3H 4R2, Canada

Along-strike variations within the continent-ocean transition (COT) are typically poorly constrained due to uncertainties when observed only along dip profiles. For example, across the northeastern Scotian margin previous wide-angle seismic studies of profiles OETR-2009 and SMART-1 indicate continental crustal thinning in a magmapoor setting, which leads to mantle serpentinization within the COT. However, although the two profiles are only 100 $\mathrm{km}$ apart, exhumed serpentinized mantle is interpreted along the SMART-1 (upper transitional crust) but not along the other profile. To further investigate the implied alongstrike variability of mantle exhumation and test the different interpretations of the transitional crust, we acquired OCTOPUS wide-angle seismic data in 2010 along a $240-\mathrm{km}$ long profile. This is coincident with the eastern end of the MCS profile GXT-5100, intersecting perpendicularly with OETR-2009, and SMART-1 within the COT.

Analyses of data from 19 ocean-bottom seismometers deployed at 10-km spacing and supported by the coincident MCS reflection section resulted in a detailed $P$-wave velocity model. This model shows a mostly laterally uniform sedimentary section except for the Valanginian-Hauterivian turbiditic channels which pinch-out northeastward. The crustal structures underneath are, however, highly variable forming three distinctive velocity patterns. Pattern I, modelled at 25-15 km southwest of profile OETR-2009, is interpreted as exhumed serpentinized mantle with velocities of $5.5-7.5 \mathrm{~km} / \mathrm{s}$ and an extraordinarily high vertical gradient $(\sim 1.1 / \mathrm{s})$ above a slightly serpentinized mantle layer of reduced mantle velocities $(7.5-8.0 \mathrm{~km} / \mathrm{s})$ down to $3.5 \mathrm{~km}$ beneath the basement top. In Pattern II at 0-25 km northeast of SMART-1, a very thin (1-2 km) upper crustal layer with velocity of $\sim 5.2 \mathrm{~km} / \mathrm{s}$ is modelled above a thick $(\sim 6 \mathrm{~km})$ layer of moderately to slightly serpentinized mantle layer (velocity $\sim 6.4-7.9 \mathrm{~km} / \mathrm{s}$ ). For the rest of the transitional crust, we modelled Pattern III where a lower crust $(\sim 0.7-3.0$ $\mathrm{km}$ thick and with velocity of $6.1-6.6 \mathrm{~km} / \mathrm{s}$ ) is modelled and interpreted as lower crustal gabbroic Layer 3 found between the upper crust and a slightly serpentinized mantle layer. The Moho discontinuity modelled using the wide-angle data coincides with strong reflections in the MCS section. Therefore, serpentinized mantle seems to be distributed regionally under the thin crust, but mantle exhumation appears to be of much more limited extent.

\section{Exploration of the Chidley Basin, offshore Newfoundland and Labrador, Canada}

Erwan Le Guerroué ${ }^{1}$, Paul Jermannaud ${ }^{1}$, Pierre-Yves Filleaudeau ${ }^{1}$, Guillermo Perez-Drago ${ }^{1}$, Pierre-Yves ChenET $^{1}$, ERin Gillis ${ }^{2}$, Victoria Mitchell ${ }^{2}$, Nicholas MONTEVECCHI $^{2}$, AND RICHARD WRIGHT ${ }^{2}$

\section{Beicip-Franlab, 232 av. Napoléon Bonaparte, Rueil-Malmaison 92500, France 9 \\ 2. Nalcor Energy Limited, 45 Hebron Way, St. John's, Newfoundland and Labrador A1A 0P9, Canada}

The underexplored Chidley Basin off the Labrador coast of Newfoundland and Labrador, Canada, is being investigated for oil and gas prospectivity with the acquisition of new $2 \mathrm{D}$ seismic data in 2011-2015. Presented here are the results of the integration of the geological and geophysical data into a comprehensive 3D stratigraphic model. The basin assessment workflow includes: (1) regional geodynamic and tectonic setting definition; (2) analysis of the gross depositional environment and reservoir characteristics combining sedimentology and sequence and seismic stratigraphy; (3) forward stratigraphic modeling of Cretaceous and Cenozoic sequences; (4) source rock assessment, potential and regional extents; (5) play definition; and (6) testing of the play elements of a potential petroleum system.

Regional geodynamic interpretation (structural fault pattern and timing and oceanic chrons) and seismic sequence stratigraphic work facilitated the understanding of the basin architecture and infilling through the Labrador Sea opening and transform fault zone activities. This tectonostratigraphic framework provided the inputs of gross depositional environment maps that ultimately enabled building a forward stratigraphic model (DionisosFlow ${ }^{\mathrm{Tm}}$ ).

This forward numerical model simulates the stratigraphic record of the basin through forward simulation of sediment influxes under reconstructed paleobathymetric conditions. The model is calibrated against well record (lithologies, facies and paleoenvironment interpretations) and integrates seismic data (structural and depositional thickness of main packages). The model helps to resolve the extension of known, hypothetical, and/or speculative source rocks, reservoirs quality and distribution, carrier beds, and seals at the basin scale. Based on this comprehensive regional stratigraphic understanding, seven hydrocarbon plays were identified in the basin, defining a complete petroleum system that will be the focus of upcoming exploration license rounds. 


\section{An opportunity to re-evaluate the petroleum potential of the Douala Basin, Cameroon}

Jean-Pierre Loule ${ }^{1}$, Francis Jifon ${ }^{1}$, Serge E. A. Biouele ${ }^{1}$, Ponce Nguema ${ }^{1}$, David J. A. Spofforth ${ }^{2}$, Daniel Carruthers ${ }^{2}$, Carl Watkins ${ }^{3}$, AND Joe JOHNSTON $^{3}$

1. Société Nationale des Hydrocarbures (SNH), Rue 1877, Yaoundé, Cameroon 9

2. CGG MCNV (GeoSpec), Tyn-y-Coed, Pentywyn Road, Llandudno, Wales LL30 1SA, United Kingdom g

3. CGG GeoConsulting, Tyn-y-Coed, Pentywyn Road, Llandudno, Wales LL30 1SA, United Kingdom

The Douala Basin is the northernmost basin formed during rifting and separation of the South Atlantic conjugate margins, a province harbouring prolific accumulations of hydrocarbons. Previous exploration across the Douala Basin has identified potential in both slope and deepwater systems, albeit with limited success from a small number of wells. Now, for the first time, legacy 2D and 3D seismic datasets have been zero-phased and time and amplitude matched (TerraCube ${ }^{\mathrm{REGRID}}$ ) to generate a contiguous seismic volume of more than $7500 \mathrm{~km}^{2}$ and $28000 \mathrm{~km}$ of $2 \mathrm{D}$ seismic. Utilizing the latest seismic interpretation and stratal-slicing techniques, the depositional environments and fault systems of the complete offshore system, from shelf to basin floor can be explored in extraordinary detail. Interrogating available well data within this wider geological context provides a more robust assessment of previous exploration efforts and the basin's prospectivity. This workflow suggests a number of reasons for supposed well failure across a number of case studies including; poor well position, inadequate testing programs, or poor geological concepts, meaning wells were always likely to fail. Future success in the Douala Basin undoubtedly relies on utilization of the latest seismic datasets and interpretation techniques to generate new play concepts in order to unlock the true economic potential in the Douala Basin.

\section{Investigating the presence of boudinage structures offshore Newfoundland, Canada, using geophysical data}

\section{Malcolm D. J. MacDougall, Alexander Braun, and Georgia Fotopoulos}

Department of Geological Sciences and Geological Engineering, Queen's University, Kingston, Ontario K7L 3N6, Canada

The evolution of the passive margin off the coast of eastern Canada has been characterized by a series of rifting episodes that resulted in widespread extension of the crust and associated structural anomalies, some with the potential to be classified as boudinage structures. These features are segments within the subsurface formed during lithospheric stretching and rifting, which begin as pinchand-swell structures among structurally competent layers of strata bound by incompetent layers, and later separate into discrete boudins. Crustal thinning of competent layers is often apparent in seismic sections or appears as repeating elongated anomalies in gravity and magnetic surveys.

In general, boudinage at the lithospheric scale develops undulation wavelengths approximately four times the competent layer thickness. Additionally, the presence of listric faults and Moho undulations is thought to be related to these regimes and such features have been identified in gravity, magnetic, and seismic surveys. By comparing the evolution of the Grand Banks to other examples of passive margins where boudinage has been suggested as a driving mechanism, it is reasonable to explore the potential of the same structures being present in the Newfoundland margin. Some useful analogues include the Greenland-Norway and Brazil-West Africa conjugate margins, the South China Sea, and the Basin and Range province in the western USA.

This investigation will supplement our knowledge of the aforementioned examples with a thorough investigation of seismic, gravity, and magnetic signatures, in order to determine if boudinage structures are evident in the context of the Grand Banks. The identification of boudinage in geophysical data from the Grand Banks is challenging because it is a more complex passive margin segment. However, the application of these methods to the Grand Banks is valuable due to the economic prospects and the potential for increasing geological knowledge of the area, as well as validating existing model results of extensional margin evolution. 


\section{A palynological Triassic-Jurassic boundary section in the salt-bearing Argo F-38 well, Orpheus Graben, offshore Nova Scotia, Canada}

\section{R. Andrew MacRae and Stephen K. Rankin}

Department of Geology, Saint Mary's University, Halifax,
Nova Scotia B3H 3C3, Canada

The Late Triassic-Early Jurassic fill of the Scotian Basin represents the initial rift and drift tectonics of the Atlantic Ocean. Deposition included the evaporites that control salt tectonics across the margin, but their paleoenvironment and age are relatively poorly constrained due to few well penetrations and no biostratigraphy other than terrestrial palynology. This study examines Middle Jurassic and older palynology and geochemistry in the Argo F-38 well, which penetrates relatively undeformed salt-bearing strata into basement in the Orpheus Graben.

Passing down-well, a normal marine, dinoflagellatebearing Middle Jurassic (Bajocian-Bathonian) interval is abruptly replaced at $2232 \mathrm{~m}$ (KB MD) by Early Jurassic, terrestrial-palynomorph-dominated strata, the contact perhaps representing an unconformity. The assemblage is dominated (mostly $>90 \%$ ) by Classopollis species, but also present is Echinitosporites sp. A, Callialasporites dampieri, Kraeuselisporites reissingeri, Ischyosporites variegatus, Cerebropollenites sp., and other miospores. Rare acritarchs are present in the main salt-bearing interval $(2305-3112 \mathrm{~m} / 807 \mathrm{~m})$. Not associated with other reworked palynomorphs, they may indicate that more hospitable conditions were intermittently present between episodes of salt deposition.

Above $2950 \mathrm{~m}$, bromine concentration in salt ranges from 60 to almost 200 ppm, typical of Scotian and Grand Banks Argo Formation. Deeper than $2950 \mathrm{~m}$, Br concentration incrementally drops below $60 \mathrm{ppm}$ to as low as $5 \mathrm{ppm}$, typical of the transition to older Osprey Formation on the Grand Banks. Despite this hint of changing conditions, palynomorphs are largely the same. By $3136 \mathrm{~m}$, slightly below the main salt interval, the presence of Anapiculatisporites spiniger and decline in Classopollis torosus abundance versus increasing $C$. meyeriana implies proximity to the Triassic-Jurassic boundary. Although uncertain due to possible caving, it is notable that slightly higher within the 3081-3112 m interval, certain Early Jurassic species make their last consistent down-hole occurrence, a base used as a marker just above the Triassic-Jurassic boundary in other parts of the world.

The bottommost sample at $3325 \mathrm{~m}$ still has Classopollisdominated assemblages with a single occurrence of Patinasporites densus, a Rhaetian (Late Triassic) marker, consistent with entry into the Triassic before Paleozoic basement. Comparison to other wells in the region and across the Atlantic suggests that a consistent pattern of salt deposition may exist in the Central Atlantic region.

Formation and restoration of the diachronous, polyphase southern North Atlantic: links between the IberiaNewfoundland and neighbouring rift systems

Gianreto Manatschal ${ }^{1}$, Michael NirRengarten ${ }^{2}$, AND Pauline Chenin ${ }^{3}$

1. Institut du Physique du Globe de Strasbourg (IPGS);

UMR 7516, Université de Strasbourg/EOST, CNRS,

Université de Strasbourg, 1 rue Blessig, Strasbourg 67084, France 9

2. Department of Geo Sciences and Environmental Sciences, Université Cergy-Pontoise, 33, boulevard du Pont, Cergy-Pontoise Cedex 95011, France 9

3. IPGS-CNRS-EOST, Université de Strasbourg, 1 rue Blessig, Strasbourg 67084, France

The southern North Atlantic resulted from polyphase and diachronous rift evolution that gave rise to a remarkable diversity of key architectural features, including alongstrike segmentation and variable degrees of asymmetry. The pronounced architectural and temporal variability depend on a number of fundamental parameters, including the thermal state, composition of the crust and lithospheric mantle, extension rates, rheological evolution, and the timing and volume of magmatism. Thanks to extensive datasets, these parameters are relatively well-constrained for the Iberia-Newfoundland margins, but much less for the neighbouring rift systems. In our presentation, we discuss: (1) the conditions at onset of rifting and how they may have influenced the rift evolution; (2) the timing of crustal thinning and breakup; and (3) the kinematic evolution of the Iberia-Newfoundland and adjacent rift systems.

Our presentation aims to link, on a first-order basis, the structural/lithospheric and magmatic/asthenospheric processes controlling rifting and final breakup in the southern North Atlantic. The complex kinematic evolution of this rift system may indeed reflect the interplay between inheritance (innate/"genetic code") and the physical processes (acquired/external factors) at play during formation of the Iberia-Newfoundland and surrounding rift basins. Through this contribution, we highlight that reliable descriptions of rift systems require both an understanding of their kinematic evolution and of their inheritance in order to understand how rift systems interact, evolve, and finally rupture or abort. 


\section{Petroleum system modeling offshore Nova Scotia, Canada: an insight on its hydrocarbon potential}

\author{
EMERSON MARFisi ${ }^{1}$, Francky SAINT-ANGE ${ }^{1}$, LAURENT \\ Cullhe $^{1}$, Adam MacDonald ${ }^{2}$, And Matt Luheshi ${ }^{3}$ \\ 1. Beicip-Franlab 232, avenue Napoleon Bonaparte BP 213, \\ Rueil-Malmaison 95202, France 9 \\ 2. Nova Scotia Department of Energy, Halifax, \\ Nova Scotia B3J 3P7, Canada 9 \\ 3. Leptis E\&P Ltd., Watford, Hertfordshire \\ WD17 4QX, United Kingdom
}

The presence of an active petroleum system in the Central Scotian Shelf (CSS) has been known since 1969 with the first discoveries of oil and gas in the Sable Island area. Since that time, 31 significant discoveries have been reported from 123 exploration wells drilled mostly on the CSS. Seven deepwater wells were drilled on the slope finding gas-bearing reservoir sands. Two found gas: Annapolis G-24 (27.3 m net pay) and Newburn H-23 (5.5 m net pay), thus confirming an active slope petroleum system exists but remains poorly understood.

Since 2009, a number of studies evaluated the hydrocarbon potential of the entire Scotian Basin petroleum system and deep offshore areas. Numerical petroleum system models were generated in the framework of each of these studies. Potential source rock (SR) intervals defined in these models included: Early Jurassic (Sinemurian-PliensbachianToarcian), Middle Jurassic (Callovian), Late Jurassic (Tithonian), and Early Cretaceous (Valanginian-Aptian).

There is currently no strong evidence for the presence of the Early Jurassic SR in offshore Nova Scotia but evidence of their presence in Morocco supports this possibility. A kinetic reaction for a Type II kerogen was assigned to the Early Jurassic SR with $2.5-5 \%$ TOC and HI $=600 \mathrm{mg} \mathrm{HC} / \mathrm{g}$ TOC. middle to late Jurassic SRs were considered as a mix Type II-III kerogen with 2-3 \% TOC and HI = $424 \mathrm{mg}$ $\mathrm{HC} / \mathrm{g}$ TOC. The Valanginian and Aptian SRs were set as predominantly Type III kerogen with 1-2 \% TOC and HI = $235 \mathrm{mg} \mathrm{HC} / \mathrm{g}$ TOC.

A number of fluid carrier and reservoir units were defined from the Abenaki (Scatarie Mb.) to Logan Canyon and Wyandot formations. SR maturation was simulated using a coupled crustal-sedimentary cover thermal model reproducing heat-flow from $200 \mathrm{Ma}$ to present-day. Thermal results shown that the Early-Middle Jurassic SRs, if present, would reach the oil window as early as $180-160$ Ma and over-maturity $\sim 140-100 \mathrm{Ma}$ through the northeast and central areas of the Nova Scotia Margin decreasing in maturity to the Shelburne Sub-basin to oil/wet-gas window. The Tithonian SR reached the oil window at $120-80 \mathrm{Ma}$ in the northeast-central the part of the margin with favorable conditions to expel liquid hydrocarbons and gas all along the slope. The risk for suitable HC generation conditions seems to be low in the Scotian Basin for Jurassic SRs, and locally Early Cretaceous sources. Present challenges are oriented to a better understanding of the sedimentary architecture in the slope and basin areas.

\section{The aeolian Triassic rift fill sediments at Red Head, Five Islands, Nova Scotia, Canada}

\section{Kenneth Martyns-Yellowe, Darragh E. O’Connor, Ricardo L. Silva, AND Grant D. WaCh}

Dalhousie University, Basin and Reservoir Lab, Department of Earth Sciences, Life Sciences Centre, Halifax, Nova Scotia B3H 4R2, Canada

We examine the outcrop sedimentological, mineralogical, and geochemical characteristics of the Late Triassic Red Head Sandstone Member (RHS), Wolfville Formation, located at Five Islands Provincial Park, Nova Scotia. The RHS comprises approximately $33 \mathrm{~m}$ of red quartzitic sandstone interpreted as an aeolian dune field complex deposited in an arid to semi-arid environment. The type section is an amphitheatre with complete internal 3D visualization of the succession. The aeolian strata overlie alluvial/fluvial sandstone of the Carnian Wolfville Formation and are overlain by playa lacustrine mudstone of the Norian Blomidon Formation.

In Mesozoic rift basins along the Eastern North American Margin, this interval is one of the only locations which exhibits the transition between the major alluvial/fluvial and lacustrine rift fill succession. Previously regarded as the uppermost unit of the alluvial/ fluvial Wolfville Formation, recent biostratigraphic work revised the RHS as the lowermost member of the playalacustrine Blomidon Formation.

This work integrates comprehensive literature review, outcrop sedimentological observations, and petrographic thin section and preliminary geochemical analysis of hand samples to classify the RHS. Preliminary distinction of lithic characteristics between the RHS and adjacent lacustrine strata of the Blomidon Formation result from mineralogical and X-ray fluorescence (XRF) analysis. Despite similarities in paleoclimate, preservation of thick aeolian sandstone is generally uncommon elsewhere along the Eastern North American Margin, but sedimentological and stratigraphic similarities can be drawn with preserved aeolian sandstones in the Argana Basin, Morocco.

Like its correlative section the Tadrat Ouadou Member of the Bigoudine Formation, Morocco, the RHS sits on an angular unconformity. Both aeolian sandstones are extensive, which may be attributed to their proximity to the sand source. Preservation of both strata may be linked 
to a high paleo-water table, useful indication of a shift away from arid conditions in the Late Triassic into more humid Jurassic conditions. These results indicate the role of climate in the localization of these dune sequences in their respective tectonostratigraphic framework as well as their importance for constraining Pangaean paleoclimatic models.

\section{Stratigraphy and sedimentology of the Lower Missisauga and Mic Mac formations in the Migrant rollover structure, Sable Sub-basin, offshore Nova Scotia, Canada}

Kenneth T. Martyns-Yellowe ${ }^{1}$, Grant D. WaCh ${ }^{1}$, And NEIL WATSON ${ }^{2}$

\section{Dalhousie University, Basin and Reservoir Lab, Department of Earth Sciences, Life Sciences Centre, Halifax, Nova Scotia B3H $4 R 2$, Canada 9 \\ 2. Atlantic Petrophysics Limited, 310 - 4 Claxton Close, Nova Scotia B3M 4J5, Canada}

The deltaic reservoirs of the Lower Cretaceous Missisauga and Upper Jurassic Mic Mac formations are a highly prospective interval for hydrocarbon exploration in the Sable Sub-basin with many gas and condensate discoveries and some production. Targeted by the Migrant N-20 well, the Migrant structure is a four-way dip closure formed on the hanging wall of listric growth fault. This part of the sub-basin has an active petroleum system and abundance of reservoirs, and yet, the sands in this structure are almost entirely wet.

Based on detailed seismic mapping and interpretation, petrophysical analysis, construction of a geocellular model, reservoir simulation model, and associated Allan diagrams, it was determined that a small crestal fault (just above seismic resolution) has sufficient offset to allow crossfault leakage between reservoirs. As a result, hydrocarbons migrated cross-fault and up-section to levels that are not within four-way dip closure.

From preliminary petrophysical analysis, an anomalous bottom sand interval at the base of a fining upward sequence in the lower sections of the N-20 well resembles a pulse of deltaic sedimentation comprising a high net-to-gross deltaic sequence followed by a slowly transgressing sequence. Given the absence of cores at Migrant, it is almost impossible to directly analyze this anomalous sand unit. Instead, we must correlate the unit to nearby cored wells to visualize the facies change.

Considering the fault sealing mechanism in the genetically related Thebaud structure (a possible analogue to Migrant), we elected to use full diameter cores from the Thebaud E-74 (T5) production well that captures non-reservoir (shaley) transition and their associated features. In this presentation, we describe the facies change from non-reservoir to reservoir and back to non-reservoir sequences in the Thebaud E-74 (T5) well with emphasis on the Thebaud A/B sands in the over-pressured interval (4922-4948.5mRT). Further, we analyze the change in depositional environment and their associated energy levels to illustrate the possibilities at Migrant.

Crestal faulting as a cause of trap integrity loss and gas migration in the Migrant structure, Sable Delta, offshore Nova Scotia, Canada

Kenneth T. Martyns-Yellowe, Grant D. Wach, Frank W. Richards, and Neil Watson

Dalhousie University, Basin and Reservoir Lab, Department of Earth Sciences, Life Sciences Centre, Halifax, Nova Scotia B3H 4R2, Canada

Shelf margin deltas like the Mississippi, Amazon, Niger and the ancient Sable Delta host some of the world's largest gas accumulations. They are localized by the interaction of gravity-driven extension, syntectonic sedimentation, and salt mobilization processes. These processes impact the evolution of faults and the formation of complex structures that may in turn control the accumulation and distribution of reservoirs and hydrocarbons. Since 1959, hydrocarbons have been explored for in Nova Scotia's offshore region. Results of this exploration show that fault-controlled rollover anticlines contain significant/commercial volumes of hydrocarbons (mainly gas), with $75 \%$ of the discoveries in the Sable Sub-basin on the shallow water Scotian Shelf in these structures.

Located in the Sable Sub-basin, the Migrant structure is a fault-controlled, four-way dip anticlinal closure that formed as one of a series of related structures during salt mobilization in the Cretaceous. The Migrant N-20 well (1978) was drilled to test for hydrocarbons trapped in Late Jurassic to Early Cretaceous deltaic and fluvial-deltaic reservoirs in the Mic Mac and Missisauga formations, respectively. A drill stem test in the Mic Mac Formation flow-tested to the surface gas from a deep sand reservoir with a reported flow rate of 10 million SCF/D with associated decline over the duration of the test. The well's inability to demonstrate a sustained flow rate indicated that the discovery was non-commercial. Further geologic analysis showed diminishing net porous sand with little evidence of extensional crestal faulting deep in the core of the Migrant rollover anticline.

Integration of $3 \mathrm{D}$ seismic with well data allows us to investigate the attributes of the Migrant structure as a potential hydrocarbon trap. Through a combination of pressure data at Migrant and 3D geocellular models 
populated with input parameters such as shale volume, porosity, water saturation and permeability calculated in Petrel from key wireline logs, we relate fault distribution and seal versus reservoir properties offset in an Allan diagram. From our models, we examine the inferred mechanism for leakage at Migrant (the crestal fault), and further, model leakage volumes with varying fault displacements, seal thicknesses/net to gross ratios and permeabilities. The new interpretations and results from this study will be useful for de-risking future exploration and development of ancient deltaic systems along the Atlantic margin including the undrilled Shelburne Delta in southwest Scotia Basin, potential deltas off Labrador, and the Iberian and Moroccan conjugate margins.

\section{Structural and depositional controls on Plio-Pleistocene submarine channels: the Taranaki Basin as an analogue for North American continental margins}

\section{Nathalia H. Mattos and Tiago M. Alves}

3D Seismic Lab, School of Earth and Ocean Sciences, Cardiff University, Main Building-Park Place, Cardiff, Wales CF10 3AT, United Kingdom

High-quality 3D seismic data are used to investigate the geometry of submarine channels in the Northern Graben of the Taranaki Basin, New Zealand. The distribution of lithologies, the large-scale geometry of submarine channels, and the structural controls in the Taranaki Basin may resemble depositional elements observed in sedimentary basins in eastern Canada.

The Parihaka Fault, as one of the most distinctive structures of the Cape Egmont Fault Zone, comprises four segments with variable vertical displacements in the study area. Thus, this talk will focus on the geometry of four representative channel systems incising the Giant Foresets Formation as a function of Plio-Pleistocene faulting. The successive formation of new fault segments to the north controlled the development of channels on both the footwall and hanging-wall blocks. Channel deflections also reflect structural controls on the channel configuration, combined with significant sediment inputs.

To assess channel distribution throughout the study area, seismic attributes including variance, instantaneous frequency, generalised spectral decomposition and reflection intensity were applied to reveal the amplitude anomalies that (1) highlight variations in lithology; and (2) outline the channel geometry. As a result, we identify three drainage types in the study area: oblique, transverse and parallel to the Parihaka Fault trace. A channel density plot was created based on the identification of Channel Points (CP) on the channel edges and compared to an isochron thickness map of channel-fill deposits. We found a discrepancy between channel density and the thickness map, as the areas of maximum sediment supply are positioned on the footwall of the Parihaka Fault, while two depocentres are located in the northeast part of the study area.

This work shows that relay zones developed between the Parihaka Fault segments had limited influence on channel location. Channels developed close to the transfer zone were diverted from their original courses close to the Parihaka Fault segments and flowed transversally to the fault trace instead of running through the relay ramps. Hence, we invoke that the sediment fed setting recorded along the Parihaka Fault was important enough to limit the influence of this structure on sedimentation, thus imposing a very moderate control of faulting on channel incision. Similarities between this case study in New Zealand and basins in Eastern Canada will provide insights into the distribution of faults and sediment deposits and implications for petroleum systems in both areas.

Breakup in the presence of plume magmatism: implications for South Atlantic tectonostratigraphy

Ken G. McDermott ${ }^{1}$, Elisabeth C. Gillbard ${ }^{1}$, Paul T. BELLINGHAM $^{1}$, AND BRIAN W. HORN ${ }^{2}$

\section{ION, E \& P Advisors, 31 Windsor Street, Chertsey, Surrey KT16 8AT, United Kingdom g \\ 2. ION, E \& P Advisors, 2105 City West Boulevard, Suite 400, Houston, Texas 77042-2839, USA}

Rifted continental margins are often considered independently due to a paucity of conjugate high-resolution reflection seismic profiles. Here, ION's South Atlantic mega-regional, conjugate seismic datasets are reconstructed to be considered as they once were; a single basin with a shared geological history. Observations from these seismic data provide new and important insights into the principle mechanisms involved in highly magmatic continental breakup.

The conjugate margins of the austral South Atlantic are classically magma-rich with well-developed examples of all typical volcanostratigraphic elements observed on magmarich margins globally: stretched continental crust, inner and outer SDR packages, outer high, a zone of high-velocity lower crust, and relatively thick early oceanic crust.

Through well-correlated stratigraphic and crustal structure interpretation, a new tectonostratigraphic model for the formation of the austral South Atlantic is developed that may have applications to equivalent margins influenced by plume magmatism. The model consists of four distinct crustal domains (continental, magmatic, oceanic, and oceanic plateau), and two important crustal boundaries; 
the limit of continental crust, and limit of oceanic crust. The tectonostratigraphic model also describes strongly diachronous post-rift and drift phase subsidence and highlights the role the Walvis Ridge - Rio Grande Rise (WRRGR) system played in the separation of the central and austral segments of the South Atlantic Ocean. Detailed analysis of subsidence patterns on both conjugate margins indicate that for much of the Lower Cretaceous, the WRRGR system formed a barrier that totally separated the austral and central segments of the South Atlantic basin. However, during Aptian times, renewed extension localized on the African Margin, stretching the WRRGR amagmatically, led to the formation of what we term the "Walvis Straits". Once the straits were formed seawater had a pathway to flow northwards and evaporate, contributing to the development of the Great South Atlantic Salt Basin.

The observations and processes described here underpin the development of a regional petroleum systems model, allowing prediction of regional heatflow through time as well the likely location of source and reservoir lithologies across the entire austral South Atlantic Basin reducing exploration uncertainty of for the discovery of commercial hydrocarbons.

\section{Hybrid breakup: spanning end-member models towards a full tectonostratigraphic understanding of the central South Atlantic}

\author{
Ken G. McDermot T ${ }^{1}$, Neil Hurst ${ }^{1}$, Paul T. \\ BELlinghaM $^{1}$, AND BRIAN W. HORN ${ }^{2}$ \\ 1. ION, E \& P Advisors, 31 Windsor Street, Chertsey, Surrey \\ KT16 8AT, United Kingdom g \\ 2. ION, E \& P Advisors, 2105 City West Boulevard, Suite 400, \\ Houston, Texas 77042-2839, USA
}

Rifted margins are often considered as end-members: magma-poor and magma-rich. Investigations into magmapoor breakup processes (crustal hyper-extension, partial serpentinization, and exhumation of sub-continental mantle) have focused on the North Atlantic (e.g., IberiaNewfoundland Rift System) and Tethyan rifted margins preserved in the Alps. Similarly, the processes of magmarich breakup (continental crust "replaced" by mafic crust through voluminous magmatic addition) and its characteristic SDR sequences have been studied on the North and South Atlantic margins, and onshore Greenland and Mozambique. However, it is becoming clear that in viewing margins as end-members, key developmental stages for many rifted margins are unaccounted for, as is the case for the central South Atlantic. Instead, we should consider the rifted margins as forming a spectrum and think in terms of a new class of margin, the hybrid-rifted margin.

ION's $72000 \mathrm{~km}$ central South Atlantic conjugate BasinSPANTM reflection seismic dataset has been utilised to produce a mega-regional tectonostratigraphic model. The model delineates crustal domains along the margins relating to continental stretching and breakup, highlighting diachronous rifting and partitioning of extensional strain across the margin resulting. The data also show how the central South Atlantic cannot be described in end-member terms, but instead should be considered as a hybrid margin. Our interpretation reveals a magma-poor rift beneath the sag-basin transitioning to magma-rich oceanward. Mapping of the pre-salt sag sequences shows oceanward migration of extension forcing progressively younger strata to become effective synrift while their chronostratigraphic equivalents thermally subside (effective post-rift) continentward. We observe an outer high (magmatic construction) at the limit of oceanic crust forming a barrier to autochthonous salt suggesting the switch from magma-poor to magma-rich rifting exacted a fundamental control on the boundaries to the South Atlantic Salt Basin.

We conclude that a model invoking hybrid rifting is most appropriate to describe the central South Atlantic and show that how it has led to significant implications for subsidence and heat flow through time. Understanding the interplay between tectonics and sedimentation across the margins through time is therefore key to reducing exploration risk in the central South Atlantic.

\section{Influence of global mean sea level and mantle dynamic topography variations on passive-aggressive continental margins}

\section{Kenneth G. Miller, William J. Schmelz, James V. Browning, James D. Wright, and William J. Schmelz \\ Department of Earth and Planetary Sciences and Institute of Earth, Oceans, and Atmospheric Sciences, Rutgers University, 610 Taylor Road, Piscataway, New Jersey 08854, USA}

Tectonism and global mean sea level (GMSL) changes leave distinct imprints on the stratigraphic record of passive continental margins. During icehouse intervals (e.g., the last $50 \mathrm{Ma}$ ), the waxing and waning of ice sheets dominated sealevel changes on distinct Milankovitch periods (e.g., 19/23, 41, quasi-100, and $405 \mathrm{ka}$ and 1.2 Ma tilt cycles). Tectonic subsidence and uplift is superimposed on passive margin records not only on long time scales (10-100 Ma) due to thermal cooling, loading, and flexure, but also on shorter time scales due to changes in mantle dynamic topography (>1-2 Ma scale) and Glacial Isostatic Adjustment (5-30 ka scale). 
Drilling on the "passive" continental margin of the midAtlantic U.S. has provided unprecedented recovery of Upper Cretaceous to Holocene sequences. Ocean drilling has also provided a global array of ocean core holes allowing application of the $\delta^{18} \mathrm{O}-\mathrm{Mg} / \mathrm{Ca}$ proxy for ice volume. We spliced together astronomically calibrated Pacific deep sea benthic foraminiferal $\delta^{18} \mathrm{O}$ records from the past $45 \mathrm{Ma}$ and extended this compilation to $66 \mathrm{Ma}$ using lower resolution records. The splice was scaled to sea level using a smoothed record ( $>2 \mathrm{Ma}$ ) of Cenozoic $\mathrm{Mg} / \mathrm{Ca}$ variations to account for long-term bottom-water temperature changes. Our record provides an estimate of ice-volume and attendant Global Mean Sea Level changes due to ice (GMSL-I) with errors of approximately $\pm 10 \mathrm{~m}$, but is not a complete estimate of GMSL because it does not account for changes in the volume of the ocean basin, other tectonic effects, or other causes. We compare our GMSL-I records with independent estimates of million year-scale sea-level changes derived from passive margins by backstripping, progressively accounting for the effects of compaction, loading, and thermal subsidence.

Both GMSL-I and back-stripped records show synchronous $20-60 \mathrm{~m}$ variations on the million year scale during the late Middle Eocene to Miocene, suggesting that we have constrained changes in ice volume on this scale. However, there are differences between the onshore and offshore on the mid-Atlantic margin on the 1-5 Ma scale that we attribute to changes in mantle dynamic topography due to the influence of the subducting Farallon slab. The amplitude of the offsets is consistent with models of mantle dynamic topography that predict these differences. Such changes in continental elevation explain the patchwork preservation of sequences and regional differences on this "passive-aggressive" margin.

\section{Seismic inversion and source rock evaluation on Jurassic organic-rich intervals in the Scotian Basin, Nova Scotia, Canada}

\section{Natasha M. Morrison, Ricardo L. Silva, F.W. (Bill) RichaRDS, AND GANT D. WACH}

\section{Basin and Reservoir Lab, Department of Earth Sciences, Dalhousie University, Life Sciences Centre, Halifax, Nova Scotia B3H 4R2, \\ Canada}

Source rocks are a key element of a petroleum system and are identified as a risk in the exploration of the Scotian Margin, offshore Nova Scotia Canada. There have been 24 significant hydrocarbon discoveries, including eight commercial discoveries since 1967 in the Sable Sub-Basin of the Scotian Basin. Although there are proven hydrocarbon accumulations in both Jurassic and Cretaceous reservoirs, identification of their source is problematic. This is due to the low organic matter content of the studied sedimentary section, 'turbo' drilling practices, and extensive drilling mud contamination. This project investigated the extent and geochemical properties of (presumed) Middle to (known) Upper Jurassic source rocks in the Scotian Basin. It tests the hypothesis that source rocks, (if present in a $2120 \mathrm{~km}^{2}$ area surrounding Sable Island), can be identified using petrophysical techniques and then mapped using seismic inversion.

Investigation of Middle and Upper Jurassic successions and their potential as source rock was completed using a combination of petrophysical and seismic techniques. Wireline log estimation of total organic carbon (TOC) was completed using the Passey method. Seismic inversion was achieved via a $3 \mathrm{D}$ constrained sparse spike inversion, based on the presence of low impedance source rocks investigated using the Løseth et al. "Source Rock from Seismic" method. The study area was selected based on well control (with 19 Jurassic penetrations) and the availability of 3D seismic data.

The petrophysical methods did not identify intervals of source rock in the studied wells. This is consistent with the publicly available geochemical data, showing measured TOC values of generally $<2 \%$. Seismic inversion was effective in mapping low acoustic impedance intervals, especially in calcareous shales. However, without unequivocal evidence of high TOC content $(>2 \%)$, low acoustic impedance cannot be interpreted as source rock, i.e. a relationship between AI and TOC was not found. A correlation was found between low impedance calcareous shales and overpressured zones with overpressure known to lower seismic velocity. It is suggested that late hydrocarbon generation and migration in the Scotian Basin are responsible for overpressure. Hence, low acoustic impedance may provide indirect evidence of source rock presence and active or late stage hydrocarbon generation from below present well penetrations or from outside the study area.

Mixed siliciclastic- carbonate systems and their impact on the development of the Nova Scotian continental margin

\section{LOREna Moscardelli ${ }^{1}$, Jesús OCHOA ${ }^{1}$, IAN LUNT ${ }^{2}$, AND LAURA ZAHM ${ }^{1}$ \\ 1. Equinor Research and Technology, 6300 Bridge Point Parkway, Austin, Texas 78730, USA g \\ 2. Equinor Canada Ltd., 3600, 308 - 4 Avenue SW, Calgary, Alberta T2P 0H7, Canada}

The progradation of deltaic systems that reach the shelfedge is considered a primary mechanism to deliver sand to the slope and basin floor region at continental margins. 
Sediment bypass processes can dominate the outer-shelf to upper-slope transition causing poor preservation of reservoir quality sandstones in the upper slope. Turbidity flows can carry the bulk of the coarse fraction downdip with deposition of a thicker sand pile once the channelto-lobe transition is reached. Predicting this lateral and vertical variability along the slope is challenging; however, this configuration can be further complicated when mixed siliciclastic-carbonate systems are present.

In this work, we use the Roseway/Missisauga case study from Nova Scotia to explore potential implications associated with the development of deepwater turbidites within slope systems that are time equivalent to outer-shelf mixed siliciclastic-carbonate units. Two scenarios are possible: (1) the carbonate factory is still dominant and the development of extensive carbonate reefs and pinnacles in the outer shelf prevents the passage of siliciclastic systems beyond the shelf-break; in this case the siliciclastic component is sequestered within the inner/outer shelf; (2) favorable conditions for carbonate production gradually deteriorate by the activation of major fluvial/deltaic systems that prograde outboard reaching the slope region. In this second scenario, low relief and lateral discontinuous carbonate shoals tend to be ubiquitous in the outer shelf representing the last outboard remnants of the carbonate factory. Shelfedge deltas can circumvent or breach these carbonate shoals establishing sedimentary pathways in the shelf-break region that connect with deepwater turbidites. Our observations suggest that this second scenario is the more likely in this part of the Scotian margin during Berriasian to Barremian time.

\section{Coastal State extended continental shelves of the Atlantic: exploration frontiers}

\section{DAvid C. Mosher}

\section{Geological Survey of Canada - Atlantic, Bedford Institute of Oceanography, Dartmouth, Nova Scotia B2Y 4A2, Canada}

Investment in exploration in the oceans requires a known and stable regulatory framework. The purpose of the UN Convention on the Law of the Sea is to provide that framework in the context of many matters concerning the oceans. Several hydrocarbon explorationists had a major role in the drafting of article 76 of the Convention. The article, therefore, provides mechanisms for coastal States to establish the outermost limits of their sovereign rights beyond the 200 nautical miles exclusive economic zone that might include components of the margin containing hydrocarbon resources. It specifically addresses sovereign rights over the seabed and resources beneath it, and provides for rights over management of marine scientific research.

Article 76 prescribes the methodology with which a coastal State's outer limits can be established, using two formula lines and two constraint lines. The formula lines are used to identify the outer edge of the continental margin; the outermost point of the two formulae being the relevant one. The constraint lines are used to limit the extended continental shelf; again, the outermost constraint point is the relevant one. If the outer edge of the continental margin extends beyond the constraint, then the constraint is used to define the outer limit. If the outer edge does not extend beyond the constraint, then the outer edge defines the outer limit; i.e., it is the innermost point that defines the outer limit.

At this point in time, 78 coastal States havefiled submissions with the UN to propose their maritime outer limits, totaling an area of nearly $32 \mathrm{M} \mathrm{km}^{2} ; 31$ of those submissions concern the Atlantic Ocean involving about $13 \mathrm{M} \mathrm{km}^{2}$. Twenty-nine States worldwide have had recommendations issued by the Commission on the Limits of the Continental Shelf but only one Atlantic coastal State has filed final and binding outer limits with the Secretary General of the UN. Nonetheless, a coastal State has these sovereign rights ipso facto and $a b$ initio. As for the impact on exploration and development, Newfoundland and Labrador may well be one of the first regions worldwide to develop hydrocarbon resources in the extended continental shelf area.

Sand supply to a middle Carboniferous basin, western Ireland: implications for pre-Atlantic paleogeography

Martin Nauton-Fourteu ${ }^{1}$, Bébhinn Anders' ${ }^{2}$, Shame TyRrell ${ }^{1}$, AND ANDrew C. MORTON ${ }^{3}$

1. Earth and Ocean Sciences, Sediment Origins Research Team (SORT) and Irish Centre for Research in Applied Geosciences (iCRAG), National University of Ireland, University Road, Galway, Ireland $\mathbf{g}$

2. Earth and Ocean Sciences and Sediment Origins Research Team (SORT), National University of Ireland,

University Road, Galway, Ireland $\mathbf{g}$

3. HM Research Associates and CASP, University of Cambridge, Cambridge, Cambridgeshire, United Kingdom

This study investigates the provenance of deltaic sandstones of the middle Carboniferous Clare Basin, western Ireland. Provenance data from the basin fill are sparse and detailed paleogeographic reconstructions of the area are poorly constrained due to subsequent tectonism and rifting which culminated in the opening of the North Atlantic late in the Mesozoic. Potential sources, such as crystalline basement highs in the North Atlantic, have, up until recently, been poorly characterized, while other may 
be buried beneath Mesozoic sedimentary rocks or remotely located on the conjugate margin.

The Serpukhovian-Bashkirian (331-315 Ma) Clare Basin consists of a siliciclastic infill, representing deep-marine turbidites to shallow deltaic cyclothems. Previous studies, based on paleocurrent data, interpret contradictory basin infill histories with two competing models suggesting contrasting sediment input from the northwest or the southwest. Previous zircon Previous U-Pb geochronology was performed on three samples targeting the deep turbidites and two deltaic cyclothems. Results suggest a main age population of 500-700 Ma, associated with Avalonian sources which likely lay to the south of the basin. Younger (350-450 Ma) and older (>700 Ma) age populations occur in this study and could be derived from sources located north (Laurentian) or south (Avalonian) of the basin. However, in this study, the use of zircon dating alone does not help identify potentially recycled grains.

In this study, sandstones from the Tullig Cyclothem have been logged in detail and sampled at three locations. A prograding deltaic succession is observed at two of the locations with the third location interpreted as a transgressive shelf sand-body. Petrographic analyses indicate mineralogically and texturally mature sandstones. Heavy mineral analysis reveals clear changes in heavy mineral indices throughout the deposition, potentially indicating a change of source.

In order to investigate this further, zircon and apatite U$\mathrm{Pb}$ geochronology will be performed. With such mature sandstones, this multi-proxy approach is necessary to decipher any recycling from older basins. These provenance data should help better understand the fluctuating heavy mineral indices as well as better constrain the ultimate sources of these sedimentary successions. This will, in turn, help constrain Carboniferous paleogeography of the prerift northeast Atlantic Margin.

\section{New source-to-sink paradigms: how to reconcile deepwater seismic stratigraphy and geochronological observations from the Shelburne Sub-basin with current scaling relationships for fan run-out-lengths}

\section{Jesús Ochoa, Lorena Moscardelli, ANd ANdrea FILDANI}

Equinor Research and Technology, 6300 Bridge Point Parkway, Austin, Texas 78730, USA

The Upper Cretaceous stratigraphic succession (Logan Canyon Formation) in the deepwater portion of the Scotian Margin has been described as a shale-prone interval with few sandstone units. However, seismic mapping shows that channelization is ubiquitous across the margin, even though there are variations in the frequency and distribution of sedimentary pathways. Identification of this variability plays an important role in determining sandstone presence and its potential reservoir distribution along the Nova Scotia margin.

Only a few wells penetrated the Logan Canyon Formation in this region, and most of these penetrations reported shale-prone intervals with some thin-bedded sandstone. A regionally extensive mapping exercise allowed us to identify broader areas of channelization in the offshore Scotian Margin that reach the outboard region of the salt domain. These observations suggest these turbidite systems were penetrated in the bypass zone in the upper part of the slope, and thus potential exists to encounter deepwater sandstones in more distal parts of the system.

Source-to-sink understanding is increasingly critical as exploration pushes into frontier and/or unexplored basins, yet there are few examples or method-of-analysis for studying source-to-sink relationships in ancient systems. This work documents a clear example of added uncertainty in ancient systems when fan run-out lengths from the Upper Jurassic and Middle Cretaceous intervals do not scale to drainage areas. Lithological fractionation, paleoclimate, and changes in hypsometry are playing a key role controlling the fan run-out lengths. Provenance studies support sourcearea discrimination and insights on headwater uplift ages. This work documents and provides an integrated workflow for source-to-sink analysis in ancient systems.

Sedimentological evidence for Late Triassic (Rhaetian) marine incursion in the Central Atlantic Scotian Margin

\section{Darragh O’Connor, Ricardo L. Silva, and Grant D. WACH}

Basin and Reservoir Lab, Department of Earth Sciences, Faculty of Science, Dalhousie University, Halifax, Nova Scotia B3H 4R2, Canada

The onset and dynamics of early marine incursions into the basins along the Scotian Margin are not well understood. The first unequivocal evidence of marine influenced sedimentation comes from the Early to Middle(?) Jurassic dolostone-dominated Iroquois Formation. Geochemical analysis suggests that slightly older latest Triassic to earliest Jurassic salts are of marine origin, thus inferring marineinfluenced deposition before deposition of the Iroquois Formation. This uncertainty leads to two hypotheses for paleogeographic reconstructions of the Scotian Margin over this period: (1) marine ingressions resulting in salt deposition; or (2) salt generation through evaporation in an 
endorheic basin far from marine waters.

Siliciclastic successions of the Upper Triassic Eurydice Formation were cored in two drill holes in the Mohican (Mohican I-100) and Orpheus (Eurydice P-36) grabens, offshore Nova Scotia. In our investigation of these cores, identified sedimentological features are consistent with deposition by tide-dominated processes, and interpreted as deposited in an estuarine or deltaic environment. Our interpretation of the Eurydice Formation in these wells suggest that the first marine incursions into the Scotian Margin occurred during the Late Triassic, and that early rift sedimentation in the Central Atlantic margins was punctuated by recurring major changes in the depositional environments rather than a linear evolution. We interpret these marine incursions into the Scotian Margin to be contemporaneous with the main Late Triassic transgressive events recorded elsewhere in Western Europe.

\section{A schematic summary of gross depositional environments of the Scotian margin and conjugate margins of the North Atlantic from the Late Triassic to Early Eocene}

\section{Darragh O'Connor, Grant D. Wach, Ricardo L. Silva, Carlos Wong, and Taylor Campbell}

\section{Basin and Reservoir Lab, Department of Earth Sciences, Dalhousie University, Life Sciences Centre, Halifax, Nova Scotia B3H 4R2, Canada}

To better understand the nature of sediment distribution on conjugate continental margins of the North Atlantic, we have established new gross depositional environment models from the Late Triassic to the Middle Cenozoic between Atlantic Canada, Morocco, Iberia, and the British Isles. Six Atlantic-scale paleo-depositional maps are presented and show the structural development and sediment distribution of the North Atlantic from the Late Triassic onwards. These maps document the development of overall distribution and style of sedimentation and paleogeographic location of the conjugate margins. The maps show a possibly periodic connection between the Central Atlantic Margin and the Tethys Ocean during the latest part of the Triassic, the permanent incursion of Tethyan marine waters by the Late Sinemurian to Early Toarcian, and the deepening of the Atlantic by the Late Jurassic to Early Cretaceous. In addition, 18 gross depositional maps of the Scotian Margin show the detailed distribution of sedimentary successions through rifting to passive margin development from the Late Triassic to the early Late Cretaceous.

\section{How conjugate margins enhance our understanding of lithospheric processes while reducing risk in frontier exploration}

\author{
Douglas A. Paton ${ }^{1}$, Paul Markwick ${ }^{1}$, Mohamed \\ Gouiza $^{1}$, Estelle MortimeR ${ }^{1}$, AND Karyna RodrigueZ ${ }^{2}$ \\ 1. Basin Structure Group, School of Earth and Environment, \\ University of Leeds, Leeds LS2 9JT, United Kingdom $\mathbf{g}$ \\ 2. Spectrum Geo, Dukes Court, Duke Street, Woking \\ GU21 7RJ, United Kingdom
}

The availability of high fidelity reflection seismic data has transformed our understanding of passive continental margins over the past decade. Through integrating the interpretation and restoration of such seismic profiles with potential fields modelling we develop a better understanding of the geodynamic processes that drive lithospheric stretching from rifting through to margin basin formation. Furthermore, by considering these observations in the context of plate reconstructions, we can use conjugate margin restorations to constrain plate modelling and as a predictive tool for understanding the hydrocarbon systems that may be present within them.

In this study, we apply these techniques on both volcanic and non-volcanic margins and illustrate it with a series of examples from the South Atlantic, Somalia, and Bay of Biscay. Regardless of the margin type the key question is how to characterize the margin architecture. How this architecture is manifested on each of the conjugate margins plays a critical role on the development of plate reconstructions and how we understand the evolving associated basins.

In volcanic margins, central to the reconstruction is which magmatic margin model is applied, and at which point new crust is formed. This has significant impact on the heat-flow and subsidence of the conjugate sections. On non-volcanic margins many of these questions have been considered, in particular on the archetypal Iberia-Newfoundland conjugate system. In this study, we take existing models of this conjugate system and consider how applicable they are to two other examples of non-volcanic, highly extended margins. On the Somalian margin, conjugate studies require a complex three-plate reconstruction, but provide valuable insights into along-margin variations and the nature of the upper and lower plates. In contrast, the Bay of Biscay basin remains rather enigmatic especially in the context of the Iberia-Newfoundland margin but provides insights into the importance of integrating such sections into a plate reconstruction and the complexity that exists at the point of continental breakup.

Having evaluated these examples we then consider the impact that these conjugate margin studies, and the associated reconstructions, have on the petroleum systems 
that are intimately linked to the rift and drift stage of basin development.

Tectonic implications of Mesozoic-Cenozoic magmatism on the Newfoundland-Ireland-Iberian margins

\section{Alexander L. Peace ${ }^{1}$, J. Kim Welford ${ }^{1}$, Philip J. Ball ${ }^{2}$, AND NicK KUSZNIR ${ }^{3,4}$ \\ 1. Department of Earth Sciences, Memorial University of Newfoundland, St. John's, Newfoundland and Labrador A1B 3X5, Canada 9 \\ 2. Geography, Geology and the Environment, William Smith Building, Keele University, Newcastle, Tyne and Wear ST5 5BG, United Kingdom 9 \\ 3. Badley Geoscience Limited, North Beck House, North Beck Lane, Hundleby, Spilsby, Lincolnshire PE23 5NB, United Kingdom g 4. Department of Earth, Ocean and Ecological Sciences, School of Environmental Sciences, University of Liverpool Jane Herdman Building, Liverpool, L69 3GP, United Kingdom}

Successful breakup between the Newfoundland, Ireland, and Iberian passive margins resulted in the separation of the Grand Banks from Iberia, and northern Newfoundland from Ireland, whilst Ireland also separated from East Greenland. Multiple, discrete rift events have been identified prior to lithospheric breakup. Breakup resulted in the formation of a complex oceanic fracture zone, the CharlieGibbs Fracture Zone (CGFZ), surrounded by both 'magmarich' and 'magma-poor' passive margins. Previous work demonstrates the importance of studying both conjugate margins to fully comprehend rift and breakup processes. In the southern North Atlantic, it is essential therefore to compile observations from all surrounding margins to gain a better understanding of the processes governing rifting and breakup.

One aspect of passive margin development that can provide insights into the evolution of rifting and subsequent breakup is the magmatic evolution. The timing, volume, composition, and manifestation of magmatic events may vary significantly between passive margins, including conjugate pairs. As such significant information regarding rift evolution can be discerned from the series of magmatic rocks, and their spatio-temporal distribution within the rift cycle.

Location and geochronological data from magmatic rocks were compiled, and two distinct groups of volcanic rocks identified. Mesozoic-Cenozoic rocks are documented on- and offshore Newfoundland, Ireland, and Iberia cotemporaneous with rifting and breakup. In addition, a younger post-breakup magmatic event was also identified. These data were imported into GPlates for visualization within a plate tectonic context to investigate their spatial and temporal distribution. Furthermore, models of crustal thickness and regional strain evolution were compiled from previous studies. This allowed us to investigate both the viability of competing plate tectonic reconstructions and the relationship between strain, crustal thickness, and magmatism.

Results indicate that the spatio-temporal distribution of magmatism during the Mesozoic-Cenozoic development of the Newfoundland-Ireland-Iberian margins is highly variable, even between conjugate margins, and that even margins typically considered to be 'magma-poor' may host spatially, temporally, and volumetrically widespread magmatism.

Diagenetic cements in sandstones of the Scotian Basin: a
record of fluid circulation and thermal evolution

Georgia Pe-Piper

\section{Department of Geology, Saint Mary's University, Halifax, Nova Scotia B3H 3C3, Canada}

Diagenetic minerals in Jurassic-Cretaceous sandstones of the Scotian Basin preserve a record of its fluid geochemistry and thermal evolution. Diagenesis starts at the seabed, in concentric coated grains that now include chamosite, francolite, siderite and pyrite, and berthierine forms from terrestrial clay or volcanic ash coatings on sand grains. Early carbonate cement formed in transgressive or highstand firmgrounds. Where marine lowstands allowed circulation of meteoric groundwater, kaolinite and minor titania cement formed. Silica cement is widespread as overgrowths on quartz framework grains, except where quartz grains have chlorite rims, which probably developed from coats of volcanic ash or soil. Widespread ferroan calcite cement postdates silica overgrowths.

Thick sandstones commonly have pervasive secondary porosity resulting from dissolution of framework quartz and feldspar and early cements, which is partly filled by ankerite and by fibrous illite and chlorite. The last phase of diagenetic cementation includes barite, sphalerite, kutnohorite, and a titania mineral. Fluid inclusion studies show that hydrocarbon charge postdates the main phase of silica and ferroan calcite cementation and may be synchronous with the widespread dissolution. The high salinity of some fluid inclusions, $\mathrm{S}$ isotope data, and the presence of sphalerite all indicate an important role for brines from the Late Triassic Argo Formation evaporites, and outgrowths on zircon suggest zirconium mobility in hot sub-salt strata. The complex thermal history of the basin results from (a) high regional Aptian-Albian heat flow manifested by Aptian 
volcanism, and (b) episodic Cretaceous-Paleogene up-dip migration of hot brines from the deeper parts of the basin. Changing fluid chemistry and thermal conditions had a strong influence on the diagenetic evolution of the basin and hence reservoir quality.

\section{Newfoundland Orphan Basin: key structural elements for the Northeast Atlantic opening}

\section{Thibaud Pichot, Erwan Le Guerroué, Pierre-Yves FilleaudeaU, AND LuCA Micarelli ${ }^{1}$}

\section{Beicip-Franlab, 232 avenue Napoléon Bonaparte, Rueil- Malmaison 92500, France}

The Newfoundland margin has demonstrated a high hydrocarbon potential with discoveries in the Flemish Pass and Jeanne d'Arc basins, which shared common characteristics with the Orphan Basin. The recent acquisition of a large amount of high quality seismic data shed new light on the prospectivity of the margin and allow addressing key information about the structural model for the northeast Atlantic opening.

The newly imaged $800 \mathrm{~km}$-wide Orphan Basin, at the junction between the Newfoundland-Iberia and the Newfoundland-Irish rift systems, has recorded the longlasting rifting processes active in the Northeast Atlantic region during the Mesozoic. The NW-SE Late JurassicEarly Cretaceous (Neocomian) tectonic extension related to Newfoundland-Iberia rift system explains most of the structural evolution of the Orphan Basin and implies that up to $800 \mathrm{~km}$ of stretched continental lithosphere must be considered when studying the continental rifting processes between the Newfoundland and Iberia margins. The new structural analysis performed in the Orphan Basin allows for proposing a revised version of the Northeast Atlantic opening model.

The Northeast Atlantic region is characterized by Late Jurassic-Early Cretaceous extensive intracontinental rifting. Before extension, the Orphan Knoll, Porcupine High, Galicia Bank, Goban Spur, and Flemish Cap continental fragments formed a large, unstretched continental block. The western rift branch, passing through the Jeanne d'Arc, Orphan, South Porcupine, and Rockall basins, experienced several hyperextensional episodes without achieving continental breakup, whereas by the Late Aptian time the eastern branch ruptured through rift propagation between Newfoundland and Iberia.

The drastic tectonic stress change from NW-SE to NE-SW occurred at the end of the Early Cretaceous with only minor impact on the Orphan Basin (local tectonic inversion of relatively small intensity). Oblique rifting may predominate in the earliest phase of extension between Newfoundland and Northwest Europe (as recorded at the same time in the Equatorial Atlantic region). This stage ended in the Late Albian with continental breakup separating Newfoundland and Irish conjugate margins.

The study of the Orphan Basin demonstrated spatiotemporal dynamics of the Northeast Atlantic rifting controlled by: (i) the inherited structural fabric controlling the initial location and later segmentation of the margins, (ii) more than $65 \mathrm{Ma}$ of extensional regime through successive rifting stages, and (iii) drastic changes of maximum horizontal stresses.

\section{Jurassic-Early Cretaceous stratigraphy of North Atlantic sedimentary basins: a review}

\section{Colm S. Pierce, Simon Schneider, and Peter Hülse}

$$
\begin{gathered}
\text { Cambridge Arctic Shelf Program (CASP), West Building, } \\
\text { Madingley Rise, Madingley Road, Cambridge CB3 OUD, } \\
\text { United Kingdom }
\end{gathered}
$$

Integrated stratigraphies of the Jurassic and Early Cretaceous successions of more than 20 sedimentary basins situated at the Atlantic margins of North America, west and southwest Europe, and northwest Africa, were assembled for this review. Several of these basins currently produce hydrocarbons or are thought to have hydrocarbon potential. The integrated stratigraphies are based on an extensive review of the literature ( $>1,300$ publications screened) where information on lithostratigraphy, unit thicknesses, palaeoenvironments, major stratigraphic boundaries, sea-level trends, source and reservoir rocks, tectonics, magmatism, and biostratigraphy are integrated. Schematic lithostratigraphic columns are displayed, which enable comparison of sedimentary successions at regional scale and identification of regional events. Two major phases of source rock deposition were identified: Sinemurian to Toarcian and Oxfordian to Kimmeridgian. Important reservoir rocks, in contrast, are more dispersed in time. Widespread unconformities occur in the Hettangian, Callovian, Berriasian, and Late Aptian, and, taking the current low precision of dating in several basins into account, may have regional significance.

Comparative assessment of the knowledge base for a suite of basin fills allows both regional and local uncertainties to be assessed and categorized. Overall, the current state of knowledge decreases from north to south along both the western and eastern Atlantic margins. This is, on one hand, a result of limited access, with part or all of the sedimentary succession being situated offshore or in the subsurface and much of the respective data being confidential. On the 
other hand, this also clearly reflects the depth of study of the respective basins. The Wessex Basin, for example, has been analyzed in great detail, and a major portion of these data is in the public domain. The Aquitaine Basin is equally well studied, but a large part of the results is not public. For other areas, like the Essaouira and Tarfaya basins, published stratigraphy is not state of the art. For several basins, finally, no biostratigraphic or chronostratigraphic constraints are available from the literature. This detailed literature review underpinned the identification of knowledge gaps (at least in the public domain) upon which targeted outcrop-based fieldwork can shed light.

\section{Sequential hyperextension, continental faulting, and the evolution of drainage systems, southeastern Canadian margin}

\section{David J. W. Piper ${ }^{1}$, Georgia Pe-Piper ${ }^{2}$, Isabel Chavez ${ }^{2}$, AND MENG TANG ${ }^{1}$ \\ 1. Natural Resources Canada, Geological Survey of Canada (Atlantic), Bedford Institute of Oceanography, Dartmouth, Nova Scotia B2Y 4A2, Canada g \\ 2. Department of Geology, Saint Mary's University, Halifax, Nova Scotia B3H 3C3, Canada}

Provenance studies based on multiple techniques, together with deposited sediment volumes, are used to estimate relative proportions of sediment supplied from major source areas and to assess how regional faulting and uplift controlled sediment supply to the Scotian Basin. Most Jurassic sediment supply was derived locally from small rivers draining the Appalachians of Newfoundland, Nova Scotia, and Maine. Through the Tithonian to Barremian, the influence of far-travelled detritus from Labrador and New Brunswick became increasingly important, interrupted in the Aptian by a major tectonic diversion of sediment supply, and followed in the Aptian to early Cenomanian by increased supply from Labrador.

Some major tectonic changes on the actively extending margin of the Grand Banks, such as Tithonian onset of rifting, Berriasian culmination of rifting in the south and Hauterivian in the north, are recognised in the Scotian Basin and its hinterland. Other major events in the Scotian Basin, particularly in the Aptian and early Cenomanian, appear related to subtle vagaries in river pathways. Reactivation of late Paleozoic faults in the Early Cretaceous played an important role in enlarging drainage basins and changing river courses. In particular, during the Aptian the main Sable River was probably diverted westward to deposit the McMurray Formation in Alberta.

The separation of Europe and Greenland from eastern
Canada migrated progressively northward through the Cretaceous. The Aptian-Albian boundary is marked by a significant anticlockwise change in extension direction and the propagation of sea-floor spreading north of the Charlie Gibbs Fracture Zone. In the northern Appalachians, crust to the south was influenced by hyperextension along the Iberia-Goban-Porcupine and Newfoundland margin, but farther north there was only limited rifting. We evaluate whether it was mantle processes related to Tethyan subduction, or crustal processes related to hyperextension that led to dextral strike-slip reactivation of the old Paleozoic lineaments in the continent.

\section{Serpentinization in hyperextended rifted margins: possible implication for restricted basins}

\section{Victor Hugo G. Pinto ${ }^{1}$, Gianreto Manatschal ${ }^{2}$, AND AnNe MARIE KarPOFF ${ }^{2}$ \\ 1. Petrobras, Av. Rep. do Chile 330, Rio de Janeiro, Brazil g 2. Institut du Physique du Globe de Strasbourg (IPGS); UMR 7516, Université de Strasbourg/EOST, CNRS, Université de Strasbourg, Strasbourg 67084, France}

Serpentinization during mantle exhumation in magmapoor rifted margins can extend over a width of hundreds of $\mathrm{km}$ and reach down to 5-6 km. Although these observations are mainly possible in the Iberia margin where a set of ODP/ DSDP and geophysical data are available, the remnants of hyperextended domains preserved in orogens can be used to investigate the detailed relationships between tectonic evolution, serpentinization, and fluid-rock interactions in mantle, crustal and sedimentary rocks.

In order to investigate these relationships, we use field observation and structural/ microstructural analysis, petrological, and geochemical data from the remnant of magma-poor rifted systems preserved in the Alps and the West Pyrenees. Through the integration of these data with refraction data from Iberia and petrophysical data (density and $\mathrm{Vp}$ ) from serpentinites, we make a simple quantification of the amount of fluids stored in the mantle as well as the mass of elements lost during serpentinization.

Our structural/microstructural studies show that basement rocks are affected strongly by fluid circulation along extensional detachment faults as evidenced by quartz and calcite veins, and syn-kinematic phyllosilicates along fault rocks. The geochemical analysis points to enrichment of elements with mantle affinity (e.g., $\mathrm{Ni}, \mathrm{Cr}$ and $\mathrm{V}$ ) in the detachment fault and the overlying sediments. The petrological and geochemical analyses on mantle rocks point to major losses of elements that in part are incorporated 
in the fault rocks and the sediments, but also contributed to enrich the seawater. Refraction and petrophysical data allowed us to estimate the amount of seawater stored in the mantle and to quantify the mass of elements lost per $\mathrm{km} 3$ of serpentinized mantle. If one applies these results to the central segment of the South Atlantic, where evidence of mantle exhumation are observed in seismic data, the results suggest that a large amount of $\mathrm{Si}, \mathrm{Mg}$, and $\mathrm{Ca}$ may be released during mantle exhumation.

We conclude: (1) a high volume of seawater can be stored in the mantle, (2) mantle-reacted fluids, formed by serpentinization, can migrate over tens of $\mathrm{km}$ along detachment faults towards the sedimentary basins in hyperextended domains, and (3) a large mass of $\mathrm{Si}, \mathrm{Mg}$ and $\mathrm{Ca}$ can be transported from the crust/mantle in the overlying sediments and/or seawater. If these processes occur in restricted basins, such as the proto-South Atlantic at Aptian times, they can provide the elements necessary for the carbonate sedimentation and diagenesis observed in the pre-salt and may have implications for the petroleum system.

\section{Using old seismic and new analogs to evaluate USA Atlantic offshore oil and gas prospectivity}

\section{Paul J. Post ${ }^{1}$ and James L. Coleman JR. ${ }^{2}$}

\section{U.S. Department of the Interior, Bureau of Ocean Energy Management, Office of Resource Evaluation, 1201 Elmwood Park Blvd., New Orleans, Louisiana 70123-2394, USA g \\ 2. Coleman Geological Services, 130 Wesley Forest Dr., Fayetteville, Georgia 30214, USA}

Mid-1970s to mid-1980s offshore oil and gas drilling in the USA Atlantic, conjugate Northwest African Margin, the West African and South American Transform Margins, and the East African Transform Margin focused on prospects in present-day shallow water with reservoir objectives in shelf and shelf-margin environments of deposition (EODs). When successful, results were often modest. Prospects in water depths $>5000 \mathrm{ft} . / 1525 \mathrm{~m}$ were drilled by the last four wells on the USA Atlantic margin although target reservoir EODs were paleo-shelf and paleo-shelf margin. The 2001 deepwater Chinguetti discovery offshore Mauritania shifted exploration activity in Africa and South American settings analogous to the USA to deep and ultra-deepwater prospects and EODs resulting in the discovery of significant resources.

A data set of $\sim 50$ scientific DSDP/ODP, five C.O.S.T., and 46 industry wells from the USA Atlantic have been re-analyzed using new geological, geochemical, and other techniques. Combined with other new data, petroleum systems are likely to exist, with those in deepwater EODs appearing to offer largest potential.

From 1966 to 1988, ca. 239000 line miles (385 $000 \mathrm{~km})$ of 2D seismic were acquired on the U.S. Atlantic, but no 3D. Continued exploration offshore Africa and South America illustrates the evolution of seismic data acquisition and processing. Since the early 2000 s, part of the U.S. data set was reprocessed from its field tapes, with the remainder vectorized, reconstructed, and post-stack enhanced. The entire data set was depth-converted and time-migrated. Even so, areas with data quality/illumination issues exist. In addition, dip line spacing in deep and ultra-deepwater can be up to $40 \mathrm{mi}$, with no strike-oriented tie lines. This precludes prospect-scale mapping in many of the prospective settings. BOEM licensed about 185000 line miles $(298000 \mathrm{~km})$ of this "enhanced" data from GeoSpec (a CGG Company). Processing programs have improved significantly since the early 2000s and many data issues can be addressed.

Recent seismic data depicting possible analogs for potential U.S. Atlantic targets are available in the literature, company presentations, and other reports. Comparing these data with the "enhanced" seismic data from the US Atlantic margin suggests that similar oil and gas prospectivity might occur in parts of that area.

\section{Seismic characterization and hydrocarbon prospectivity of USA Atlantic offshore Late Triassic-Early Jurassic rift basins}

\author{
Paul J. Post ${ }^{1}$ and James L. Coleman JR. ${ }^{2}$ \\ 1. U.S. Department of the Interior, Bureau of Ocean Energy \\ Management, Office of Resource Evaluation, 1201 Elmwood \\ Park Blvd., New Orleans, Louisiana 70123-2394, USA g \\ 2. Coleman Geological Services, 130 Wesley Forest Dr., \\ Fayetteville, Georgia 30214, USA
}

Between 1890 and 1989, at least 87 wells were drilled in onshore, eastern USA. Late Triassic-Early Jurassic rift basins to explore for conventional oil, gas, and coalbed methane. Although no wells were commercially successful, occasionally, indications of oil and gas were encountered. Surface, subsurface, and seismic data document the components of petroleum systems in many of the recognized basins. No wells successfully drilled similar seismically identified rift basins in the USA Atlantic offshore. However, the onshore data provide valuable information to evaluate the offshore rift basins.

In evaluating onshore exploration, we considered possible causes of economic failure and whether they had commonly shared or possibly unique contributing factors as well as implications for offshore U. S. Atlantic Late Triassic-Early Jurassic rift basin prospectivity. Data interpretation data 
suggests most offshore and onshore rift basins are genetically similar in setting, synrift fill, and amount of interpreted eroded synrift. Macgregor in 1995 examined 105 rift basins worldwide and identified three broad categories of rifts and success.

All U.S. onshore and offshore Late Triassic-Early Jurassic rift basins except one appear to have undergone regional inversion, uplift, and erosion. Observations and modeling suggest that where significant $(+5000 \mathrm{ft}$. / $1.5 \mathrm{~km})$, these processes removed the sag phase of basin development and the shallowest synrift traps and/or seals. They also reduced reservoir pressures, devolitizing any trapped oils, potentially flushing the original shallower reservoirs with natural gas and other light hydrocarbons. Inversion and uplift would also reduce pressure in any remaining reservoired petroleum. Consequently, in regionally inverted rifts, potentially all conventional petroleum was lost. In locally inverted rifts, late synrift and sag phase hydrocarbon traps may be less affected. Data from the work of Macgregor in 1995 suggested that these locally inverted rifts are excellent exploration targets.

Seismic data suggests the Yarmouth rift basin in the northern Georges Bank Basin, has experienced less inversion and subsequent erosion $(\sim 2,000 \mathrm{ft} . / 0.6 \mathrm{~km})$, preserving a sag phase of basin development. Might that unique, preserved sag phase of basin development make this basin a candidate for a conventional petroleum discovery?

Petroleum systems of coastal North Carolina: what we know, what we think we know, and the range of uncertainty in the interpretation of geochemical data

Paul J. Post ${ }^{1}$, Jeffrey C. Reid ${ }^{2}$, and James L. Coleman Jr. ${ }^{3}$

\author{
1. U.S. Department of the Interior, Bureau of Ocean Energy \\ Management, Office of Resource Evaluation, 1201 Elmwood \\ Park Blvd., New Orleans, Louisiana 70123-2394, USA g \\ 2. North Carolina Geological Survey, 1612 Mail Service Center, \\ Raleigh, North Carolina 27699-1612, USA g \\ 3. Coleman Geological Services, 130 Wesley Forest Dr., \\ Fayetteville, Georgia 30214, USA
}

As part of a regional analysis of oil and gas occurrences in eastern North Carolina, the North Carolina Geological Survey initiated a comprehensive geochemical project using samples and cores from the Esso Hatteras Light \#1 (HL\#1), and Mobil State of North Carolina \#3 (NC\#3) wells. These were two of at least 19 exploration wells drilled in coastal North Carolina where oil/gas shows were reported. The study objective was to determine if the shows were in situ or represented migrated hydrocarbons.

The wells are located in a local depression on an otherwise elevated regional basement complex extending from the
Cape Fear Arch on the south to the Fort Monroe High on the southern flank of the Salisbury Embayment on the north. In the downdip, adjacent U.S. Atlantic OCS, seasurface hydrocarbon seepage slicks are identified on satellite synthetic aperture radar images and hydrocarbon-related diagenetic zones and "chimneys" interpreted on seismic data indicate vertical hydrocarbon migration. Geochemical sampling and analyses concentrated on intervals where hydrocarbons were reported in the two wells. Biomarkers in aggregated samples appear to originate from marine shale source rocks at immature/early maturity levels of thermal maturity. Oleanane suggests the hydrocarbons are Cretaceous or Jurassic age. Analytical data indicate sampled intervals are too thin, organically lean, and immature to source commercial hydrocarbons in either conventional or resource plays in coastal North Carolina. However, possible occurrences of mobile hydrocarbons were detected in Tertiary strata $(\sim 815 \mathrm{ft} . / \sim 248 \mathrm{~m})$ and solid bitumen and migra-bitumen were reported from Cretaceous rocks.

The sporadic nature of the bitumen, lack of viable source rock, and low level of thermal maturity suggest these bitumen occurrences probably lie on a migration pathway(s) rather than being in situ. Better potential may exist offshore in deepwater Assessment Units interpreted by the Bureau of Ocean Energy Management.

The crustal structure of the Porcupine Basin, offshore Ireland

Manel Prada ${ }^{1,2}$, Louise Watremez 3 , Chen, Chen ${ }^{4,5}$, Lewis Whiting ${ }^{2,7}$, Javier Fullea ${ }^{1}$, Brian M. O'Reilliy ${ }^{1,2}$, Timothy A. Minshull ${ }^{4}$, Timothy J. Reston ${ }^{6}$, Patrick ShannoN $^{2,7}$, Peter Haughton ${ }^{2,7}$, ANd Dirk Klaeschen ${ }^{8}$

1. Dublin Institute for Advanced Studies (DIAS), Geophysics Section, 5 Merrion Square, Dublin 2, Ireland 9

2. Irish Centre for Research in Applied Geosciences (iCRAG), University College Dublin, Belfield, Dublin 4, Ireland 9

3. Université de Lille, CNRS, Université Littoral Côte d'Opale, UMR 8187, LOG, Laboratoire d'Océanologie et de Géosciences, Lille, France

4. University of Southampton, University Road, Southampton SO17 1BJ, United Kingdom 9

5. National Oceanography Centre, European Way,

Southampton SO14 3ZH, United Kingdom 9

6. School of Geography, Earth and Environmental Sciences, University of Birmingham, Birmingham B15 2TT, United Kingdom 9

7. School of Earth Sciences, University College Dublin, Belfield, Dublin 4, Ireland

8. Geomar Helmholtz Centre for Ocean Research, Wischhofstraße 1-3, Kiel 24148, Germany 
The Porcupine Basin is a Mesozoic failed rift located in the North Atlantic margin (southwest Ireland), in which the amount of tectono-stratigraphic and crustal information derived from active-source seismic data has significantly increased in the last three decades, mainly because of its potential for hosting working petroleum systems. In this work, we make use of this extensive data set by combining P-wave velocity crustal models of the north and central Porcupine with surface maps of the post-rift sedimentary cover of the entire basin to derive an empirical relationship between crustal thickness and postrift sedimentary thickness. This relationship allows us to calculate first order approximation of minimum stretching factors of the entire Porcupine Basin. We then use the numerical tool LitMod1D, which allows for integrated geophysical-petrological modelling of the lithospheric thermochemical structure using gravity, seismic, thermal, electromagnetic and surface topography data, thus, allowing to explore the petrological nature of the uppermost mantle. In addition, LitMod1D is used to assess whether the empirically inferred crustal structure in the south Porcupine, where no constraints on the crustal structure are provided from active-source data, explain the present-day topography and thus is isostatically compensated.

\section{Examining controls on sediment delivery into a passive continental margin: a 200 Ma source-to-sink record on the Moroccan Atlantic Margin}

Jonathan Redfern ${ }^{1}$, Tim Luber ${ }^{1}$, Remi Charton ${ }^{2}$, LUC BULOT ${ }^{1}$, AND GIOVANNI BERTOTTI ${ }^{2}$

1. University of Manchester, North Africa Research Group, School of Earth and Environment, Williamson Building, Oxford Road, Manchester M13 9PL, United Kingdom 9 2. Tu Delft, Faculty of Civil Engineering \& Geosciences, Stevinweg 1 -2628CN, Delft, Netherlands

Detailed analysis of exposed and subsurface sedimentary successions along the Moroccan Atlantic Margin, integrated with a comprehensive data set comprising hundreds of lowtemperature thermochronology data measurements, allows reconstruction of the source-to-sink evolution between the Variscan and Alpine orogenies (300 and $100 \mathrm{Ma}$ ). The record covers the pre-, syn- and most of the postrift evolution of the margin and analysis suggests that the overall history of the margin bears little similarity with generally accepted tectono-stratigraphic models of rifted margins.

Offshore, this package is predicted to contain deepwater clastics that offer the most prospective reservoir targets, however, to date, significant thickness of reservoir quality sands have proved elusive in this underexplored basin. To reduce uncertainty, our research has focused on improving the resolution of the stratigraphic framework through extensive outcrop logging and new biostratigraphic dating. Early Cretaceous deposits are dominantly fine-grained, but discrete intervals of coarse-siliciclastic to mixed carbonate/ siliciclastic fluvio-marine deposits have been mapped.

Important lateral and temporal variability suggests a tectonic control driving the development of a forced regressive sequence in the Latest Barremian to Early Aptian, the optimum time to deliver coarse sands into the deep basin. The work recognizes local paleotopographic control on the feeder systems, both fault related and due to coeval salt movement. Small wavelength variations, extending over kilometres and with a duration of millions of years, controlled sediment sourcing and dispersal. Paleo-drainage, influenced by a set of roughly E-W-trending anticlines and N-S basin-bounding faults, and movement of tectonic and salt-driven folds on the basin margin, controlled sequence development. The detailed sedimentological and stratigraphic work has been integrated with low- $\mathrm{T}$ geochronology studies of the provenance hinterland.

This work documents a larger spatial and temporal scale of tectonics, where the entire margin was characterized by intense, tectonically driven exhumation and erosion along a NNE-SSW-trending area with a width of 100s of kilometres on the flanks of the continuously subsiding basinal domain. The results document how regional exhumation and smallscale tectonics played a significant role in the evolution of this passive margin, controlling the timing, characteristics and distribution of coarse clastics into the subsiding basins.

\section{Stratigraphy, geochemistry, and organic petrology data from the Esso Hatteras Light \# 1 and the Mobil State of North Carolina \#3 and their effect on hydrocarbon prospectivity in coastal North Carolina}

Jeffrey C. Reid ${ }^{1}$, James L. Coleman Jr. ${ }^{2}$, AND Paul J. Post ${ }^{3}$

\section{North Carolina Geological Survey, 1612 Mail Service Center, Raleigh, North Carolina 27699-1612, USA g \\ 2. Coleman Geological Services, 130 Wesley Forest Drive, Fayetteville, Georgia 30214, USA g \\ 3. U.S. Department of the Interior, Bureau of Ocean \\ Energy Management, Office of Resource Evaluation, 1201 \\ Elmwood Park Blvd., New Orleans, Louisiana 70123-2394, USA}

The North Carolina (NC) Geological Survey undertook a two-pronged geochemical study to determine if (1) hydrocarbons present in two historic wells were in situ or migrated, and (2) provide new data on the petroleum potential of the U.S. OCS offshore NC. Drilling for oil/gas in coastal NC began in 1921. Oil and/or gas shows have been 
reported in wells, and oil occurrences were described in local, early 20th century newspapers. However, no reports of oil/gas have been found in wells in similar settings in Virginia, South Carolina, and Georgia.

The study focused on intervals where hydrocarbons had been reported. Hydrocarbons are reported in a fluid inclusion stratigraphic study of the Mobil State of North Carolina \#3 well (NC\#3), and oil shows reported in postdrilling examination of cuttings and cores in the Esso Hatteras Light \#1 (HL\#1) well. The NC\#3 penetrated 7222 $\mathrm{ft} . \quad(2,201 \mathrm{~m})$ of Tertiary and Cretaceous strata overlying Precambrian granite. The down-dip HL\#1, the deepest well drilled on the NC Atlantic Coastal Plain, encountered 9878 $\mathrm{ft}$. $(3011 \mathrm{~m})$ of Tertiary and Cretaceous strata above granite.

Analyses for this current study included \% TOC, \% Ro, programmed pyrolysis, organic petrology, and biomarkers. Geological and geochemical data indicate sampled intervals are too thin, organically lean, and immature to source commercial conventional or unconventional hydrocarbons in the onshore or state waters of NC. Anomalously high \% Ro values in HL\# 1 may be due to allochthonous kerogen from nearby exposed Triassic rift basins of the Piedmont. Analyses of these basins indicate ca. 3300-10 000 feet (ca. $1000-3000 \mathrm{~m}$ ) of synrift strata were removed during their inversion, exhumation, and erosion.

The in situ or migrated nature of the hydrocarbons remains problematic, though biomarkers suggest an in situ origin. However, in HL\#1, interpreted mobile hydrocarbons were detected at $\sim 815 \mathrm{ft} .(\sim 249 \mathrm{~m})$ in Tertiary strata, and solid bitumen and migrabitumen sporadically were identified in Cretaceous rocks. These, the lack of viable source rocks, and low level of thermal maturity, suggest their relation to a migration pathway(s) - the "Carolina Ridge Complex". Both interpretations suggest a better hydrocarbon source rock potential and generation-expulsion-migration may have existed farther offshore in deep waters of the Atlantic OCS. Sea-surface hydrocarbon seepage slicks identified on satellite synthetic aperture radar images, and hydrocarbon-related diagenetic zones and "chimneys" interpreted on reflection seismic, data suggest vertical hydrocarbon migration in this area.

Southern Atlantic deepwater regional source rock evaluation

Karyna Rodriguez and Neil Hodgson

Spectrum Geo, Dukes Court, Duke Street, Woking, Surrey GU21 7RJ, United Kingdom

Most of the wells along the southern Atlantic margin were drilled in water depths below $3000 \mathrm{~m}$. However, from
NOOA's sediment thickness map, it is evident there is significant unexplored sediment thickness, $>3 \mathrm{~km}$ at greater water depths. Source rock is the first petroleum system element to be established before undertaking exploration in any frontier basin. Identifying potential source rocks on such unexplored margins requires integration of multiple datasets to build a robust geological model that fits with observations from seismic data. Plate tectonic and paleogeographic reconstructions, together with a regional geological understanding and records of Ocean Anoxic Events (OAEs), are the first recommended steps, followed by conjugate margin correlation using all available well information. The final step is seismic observation and analysis including source rock characterization, sequence stratigraphy models, and slick clusters on satellite imagery.

A large regional long offset 2D seismic dataset available along the southern Atlantic Margin has allowed the identification of an extensive source rock deposited during the transition and early drift stages of basin evolution. It is correlated from available well data in Namibia and South Africa and seems to be Aptian in age at least in the southernmost Atlantic. Its seismic character is a high amplitude reflection associated with a decrease in acoustic impedance at the top of the sequence. This is in agreement with a decrease in velocity and density resulting from high organic content. At the base of the sequence is typically a high amplitude reflection associated with an increase in acoustic impedance. Internally, it has a very distinctive low frequency, low amplitude to more homogeneous and acoustically opaque character. The sequence is usually directly overlies the breakup unconformity and even oceanic crust. The identification and correlation of this potential source rock using seismic character has been supported by integrating other seismic evidence such as BSRs (Bottom Simulating Reflectors) indicating the presence of methane hydrate, fluid pipes, pock marks, shallow gas, and nonseismic data such as oil slick clusters from optical satellite imagery.

There is very strong evidence for the presence of a regional, extensive source rock in the southern Atlantic deepwater, representing the first step in establishing a huge play fairway in that region.

\section{Source-to-sink: tracking the provenance of Lower Cretaceous reservoirs in the Essaouira-Agadir Basin, Moroccan Atlantic margin}

Emmanuel Roquette ${ }^{1}$, Stefan SchrödeR ${ }^{1}$, Tim LubeR ${ }^{1}$, Shame TyrrelL ${ }^{2}$, AND Jonathan RedFERN ${ }^{1}$

1. North Africa Research Group (NARG), University of Manchester, Williamson Building 4.69, Oxford Road, 


\section{Manchester M13 9PL, United Kingdom 9 \\ 2. National University of Ireland Galway, University Road, Galway H91 TK33, Ireland}

Untangling the complex postrift evolution of the NW African margin is fundamental to constraining the type and distribution of fluvial to shallow-marine transition feeder systems for potential deepwater reservoirs offshore. The Moroccan Atlantic margin experienced $\mathrm{km}$-scale vertical movements during the Jurassic and Cretaceous. These periods of uplift control the origin of sediments delivered to the margin and local topography, influencing distribution of the sedimentary systems.

Limited success in recent drilling campaigns reflects the poor understanding of the depositional systems from source-to-sink. This highlights the need for a more holistic approach by tracing sediment routing, the main input points through time, and storage dispersal. This integrated study aims to develop the first regional paleogeographic and tectonostratigraphic source-to-sink model of Northwest Africa by deciphering the controls, timing, and volume of the sediment supply to the margin and constraining the importance of sediment recycling, mixing and storage. A late Early Cretaceous (latest Barremian to earliest Aptian) forced regression has been identified as the main candidate interval predicted to be associated with the most significant input of clastic sediment into the deepwater basins. To assess sediment supply routing, a detailed petrographic study has been conducted integrated with SEM and QEMSCAN imagery analysis. It has demonstrated the occurrence of various granitic and volcanic clasts, mixed with recycled sedimentary grains, likely of intrabasinal origin.

Preliminary results point towards three principal source areas: the Hercynian massifs of the Western Meseta in the north; the Western High Atlas (WHA), where both Hercynian magmatism and Panafrican series are exposed; and the mixed Proterozoic series of the Anti-Atlas. Low temperature geochronology shows evidence of subsidence in the Anti-Atlas during the Late Jurassic/Early Cretaceous. This may have allowed sourcing of sediments from even further afield from the Tindouf Basin/Reguibat shield to access the basin.

The study is currently focusing on source discrimination based on the heavy mineral populations of the potential source areas and on the sampled sandstones in combination with apatite and zircon geochronology.

\section{Enigmatic aspects of the early history of the southern Gulf of Mexico margin}

\author{
MARK G. Rowan \\ Rowan Consulting, Inc., 850 8th Street, Boulder, \\ Colorado 80302, USA
}

Several aspects of the early history of the southern Gulf of Mexico are enigmatic. First, the amount of Upper Jurassic thin-skinned extension is much greater to the northeast. Second, early allochthonous flow of salt over oceanic crust is less extensive to the southwest. Third, although an outer marginal trough is apparent to the northeast, its presence to the southwest is questionable and the level of salt is higher than the oceanic crust. These observations have led to an interpretation in which the Campeche and Yucatan segments of the margin are sub-basins separated by a basement high, with the Campeche salt confined at its distal end by uplifted basement just landward of oceanic crust.

A revised explanation based on the opening history of the Gulf of Mexico nicely explains the observations. Oceanic crust was generated by the counter-clockwise rotation of Yucatan about a pole near western Cuba, with the geometry of the basin requiring a higher proportion of transform margin segments in the west and more ridge segments in the east. Three scenarios are compatible with this: (1) the onset of spreading was coeval everywhere but the amount of spreading decreased to the east; (2) the onset of spreading was diachronous, getting gradually younger eastward; or (3) the onset was diachronous but shifted abruptly across one or more transform faults.

The last option best accounts for the differences between the Campeche and Yucatan segments. First, excess thinskinned Upper Jurassic extension in the Yucatan subbasin is balanced by crustal hyperextension and/or mantle exhumation prior to oceanic spreading, whereas coeval extension in the Campeche area was accommodated by spreading. Second, the relatively minor early movement of salt over oceanic crust in the southwest is due to the dominance of transform segments and thus initially small areas of oceanic crust. Finally, outer marginal troughs are not absent in the Campeche sub-basin but are generally small and local, separated by longer transform faults. For two reasons, seismic lines across these faults show the salt higher than oceanic crust as opposed to the outer marginal troughs: first, the juxtaposed oceanic crust is relatively older and thus deeper; and second, continental crust along transform segments is often elevated along marginal ridges. 


\section{Exploration well failures and reservoir distribution along the Scotian Slope (eastern Canada)}

\author{
Francky Saint-Ange ${ }^{1}$, Nicolas Hawie ${ }^{1}$, Emerson \\ Marfisi $^{1}$, Benard Colletta ${ }^{1}$, Dimitri Savva ${ }^{1}$, Laurent \\ Cuilhe $^{1}$, Adam MacDonald ${ }^{2}$, And Matt Luheshi ${ }^{3}$ \\ 1. Beicip-Franlab 232, avenue Napoleon Bonaparte BP 213, \\ 92502 Rueil-Malmaison, France 9 \\ 2. Nova Scotia Department of Energy, Halifax, \\ Nova Scotia B3J 3P7, Canada g \\ 3. Leptis E\&P Ltd., Watford, United Kingdom
}

With 13 deepwater wells over $260000 \mathrm{~km}^{2}$, the Scotian Margin remains a frontier basin. From 2011 to 2015, exploration activities from major petroleum companies have resumed but success is slow in coming. The last two - Shell's Cheshire (2016) and Monterey Jack (2017) remain confidential. Currently, only the Marathon Annapolis G-24 (2002) and Chevron Newburn H-23 (2002) discovered gas in deepwater. Post-mortem analyses have concluded that the issue in finding viable prospects is not the petroleum system per se, but the difficulty to properly predict reservoir location due to complex salt tectonics.

The current study aims to show that coupling 3D seismic character attributes analysis with seismic stratigraphy and stratigraphic modelling will increase the probability of success. We present different cases of study across the Scotian Basin with a focus on the Central Scotian sub-basin.

In the case of the Central Scotian Basin, we hypothesized that two main factors lead to the latest well failures: (1) seismic processing that, for instance, didn't take into account seabed related interferences; and (2) misunderstanding of the depositional model which rely too much on the Gulf of Mexico analogues. We have revisited the Cretaceous depositional model and made assumptions on reservoirs distribution through space and time. We then tested the robustness of the sandstone distribution model against stratigraphic modelling using DionisoFlow ${ }^{\mathrm{mm}}$. Our geological model combined with stratigraphic modelling results suggest that significant trapping systems formed at the shelf edge during the Upper Missisauga-Logan Canyon formations (Barremian-Albian), which coincides with the timing of the salt canopy formation. Sand proportions between 10 to $25 \%$ are expected in some salt-induced minibasins downslope. There is a particular area southeast of the Tantallon M-41 well highlighting a sediment pathway showing sand proportion ranging between 20 and $25 \%$ for the studied interval.

In the case of Georges Bank and Shelburne sub-basins, the use of stratigraphic modelling was extended through the Jurassic. Results have highlighted a significant amount of Middle Jurassic and Early Cretaceous sandstones from
Georges Bank to the southern part of Shelburne subbasin. It's interesting to note that results from the 2011 PFA stratigraphic modelling in northern Shelburne Subbasin suggest the Cheshire and Monterey Jack wells were drilled outside the main carbonate play and within an area dominated by shale until the Albian.

Application of predictive modeling to the Lower Cretaceous sedimentary sequences of the central Scotian Basin

Christopher R. Sangster ${ }^{1}$, Nicolas Hawie ${ }^{2}$, Georgia Pe-Piper ${ }^{1}$, Francky Saint-Ange ${ }^{2}$, And David J. W. PIPER $^{3}$

1. Department of Geology, Saint Mary's University, Halifax, Nova Scotia B3H 3C3, Canada g

2. Beicip-Franlab, 232 Avenue Napoléon Bonaparte, Rueil-Malmaison 92500, Paris, France 9

3. Natural Resources Canada, Geological Survey of Canada (Atlantic), Bedford Institute of Oceanography, Dartmouth, Nova Scotia B2Y 4A2, Canada

The distribution and quality of the Lower Cretaceous reservoir sandstone units of the Nova Scotia offshore are poorly understood, particularly in the deep basin where few wells have been drilled. Exploration is further complicated by the widespread salt tectonism and the strong influence of diagenesis on reservoir quality. This project uses DionisosFlow ${ }^{\mathrm{TM}}$, forward stratigraphic modelling software, and CougarFlow ${ }^{\mathrm{TM}}$, statistical analysis software, to produce predictive stratigraphic models of the central Scotian Basin, and test their sensitivity. These models aim to test proposed provenance pathways, determine the distribution and extent of sands in the Scotian Basin, and to determine the factors which control their distribution.

DionisosFlow ${ }^{\mathrm{TM}}$ uses a sediment diffusion equation that simulates sediment transport with regards to water discharge, sediment load, and slope for particles with differing grain properties, which are tracked during the evolution of the basin. Sediment input parameters are based on catchment areas inferred from mineralogical provenance data and analogies with modern basins. Calibration of model results against well logs, facies, and seismic interpretations of unit thicknesses in the study area. CougarFlow ${ }^{\mathrm{TM}}$ is used to determine the relative contribution of parameters to simulation results by running large numbers of simulations with varied parameters, to generate a response surface, upon which statistical analyses are run. Subsidence, water discharge, sediment load, and mud content are tested to determine their influence on the models.

Simulation results show that proposed provenance 
pathways for the Early Cretaceous can be used to generate predictive stratigraphic models that simulate the overall sediment distribution for the central Scotian Basin. Modelling confirms that the shaly nature of the Naskapi Member (Logan Canyon Formation) is the result of tectonic diversion of the Sable River. Sand is dominantly trapped on the shelf in all units, with transport into the basin along saltwithdrawal corridors occurring in the Upper Missisauga Formation and Cree Member (Logan Canyon Formation). This led to sand accumulation in minibasins with a large deposit seaward of the deepwater Tantallon M-41 well. Sand also appears to by-pass the basin via salt corridors that lead to the down-slope edge of the study area. Sensitivity analysis suggest that source composition and salt mobility are the controlling factors of sand distribution in the central Scotian Basin.

\section{Numerically modelling Miocene stratigraphic sequences on the New Jersey shelf}

\section{William J. Schmelz, Kenneth G. Miller, and Gregory S. MountaIN \\ Department of Earth and Planetary Sciences, Rutgers University, 610 Taylor Road, Piscataway, New Jersey 08854, USA}

We have constructed a two-dimensional numerical model that produces realistic marine deltaic sedimentary structures over geological time. Fluvial sediment is supplied to the model basin from an updip origin, and is delivered to a continental shelf while maintaining an equilibrium profile that adheres to the basic principle of sedimentary mass balance. Changes in accommodation space relative to changes in sediment supply drive the spatial variation in sedimentation through time. Accommodation varies as sea level rises or falls, sediments compact, an elastic lithospheric plate is flexurally loaded, and the crust thermally subsides. The model is simple, but incorporates the primary geological and geomorphological processes that influence stratigraphic development in sedimentary basins on passive continental margins.

We tested the model against Miocene data obtained on the New Jersey continental shelf comprising $6500 \mathrm{~km}$ of high-resolution 2D seismic profiles integrated with three IODP Expedition 313 core sites. The seismic stratigraphic interpretations of sequence boundaries, lithofacies, paleowater depths, and chronostratigraphy were obtained from published materials (Miller et al., 2013). The dated seismic surfaces were converted from TWTT to depth using a velocity depth function developed for this region (Mountain and Monteverde, 2011). Two-dimensional backstripping was performed to reconstruct the seafloor topography through the Miocene, progressively accounting for the effects of compaction, flexural loading, and thermal subsidence. The model was set to run forward using the topography of the oldest backstripped layer as a starting point. At each time step, the topography produced by all permutations of a reasonable range of sea-level and sediment supply values were tested against the 'coeval' backstripped surface to select the best possible fit, producing a history of sea-level and sediment flux.

The results are considered within the context of wellconstrained paleodepth data from the IODP Expedition 313 cores and Miocene global mean sea-level (GMSL) records based on both $\mathrm{Mg} / \mathrm{Ca}-\delta^{18} \mathrm{O}$ and onshore backstripping. We will force the model using the $\delta^{18} \mathrm{O}$-based GMSL estimates to constrain and assess the sensitivity of the parameterized physical processes, including the shape of the equilibrium profile, flux of sediment input, the elastic thickness of the flexurally loaded crust, and the rate of thermal subsidence.

Fault-controlled submarine mass failure in the 1929 Grand Banks earthquake

Irena Schulten ${ }^{1}$, David C. Mosher ${ }^{2}$, David J. W. Piper ${ }^{2}$, and Sebatian Krastel ${ }^{3}$

\section{Department of Oceanography, Dalhousie University, Halifax, Nova Scotia B3H 4R2, Canada g \\ 2. Natural Resources Canada, Geological Survey of Canada \\ (Atlantic), Bedford Institute of Oceanography, Dartmouth, Nova Scotia B2Y 4A2, Canada 9 \\ 3. Institute of Geosciences, Christian-Albrechts-Universität zu Kiel, Otto-Hahn-Platz 1, 24148 Kiel, Germany}

Submarine landslides pose a significant geohazard risk to coastal communities and underwater infrastructures such as those used in offshore exploration and development. One of the first studied examples of such a geohazard is the 1929 submarine landslide on the southwestern Grand Banks of Newfoundland that caused a damaging turbidity current and ensuing tsunami. The landslide and consequent turbidity current broke 12 transatlantic telecommunication cables, and the tsunami caused 28 casualties and severe economic damage. The morphology of St. Pierre Slope does not exhibit a major headscarp, evacuation zone, and failure deposit as might be expected for such a tsunamogenic event. This study, therefore, aims to identify the failure kinematics involved in the 1929 submarine landslide. A significant amount of single- and multichannel 2D seismic reflection data of various resolutions was used to: (1) map stratigraphic horizons, (2) identify seismic facies and sequences, and (3) classify reflection relationships.

Previous studies identified the St. Pierre Slope on the 
eastern Laurentian Fan as the main source area for the sediment failure that resulted from a $\mathrm{M}_{\mathrm{w}} 7.2$ strike-slip earthquake. The landslide was described as a widespread, retrogressive failure affecting mostly the upper $20 \mathrm{~m}$ of the sediment strata. Seismic reflection sections, however, provide evidence of oblique faulting down to a sub-seafloor depth of $\sim 500 \mathrm{~m}$ with fault offsets of $\sim 75 \mathrm{~m}$ in height. Gravitational instability along deep-seated detachment surfaces in response to the earthquake presumably led to a sudden rotation of a thick $(500 \mathrm{~m})$ mass of sediment. This sudden displacement may have contributed to tsunami generation. Additionally, it may have triggered surficial sediment failures that transformed into the turbidity current that broke the telecommunication cables.

The results of this study raise concerns about marine geohazard assessments: (1) it is a passive margin setting that incurred a significant earthquake, destructive tsunami, and turbidity current, and (2) there are few morphological indicators to suggest a major sediment failure took place. Even with historic knowledge and documentation of the event, it is only through detailed study using a number of data sets of varying resolutions to ascertain potential failure mechanisms and determine the potential cause of the tsunami.

\section{A provenance study of Upper Jurassic hydrocarbon source rocks of the Flemish Pass Basin and Central Ridge, offshore Newfoundland, Canada}

\section{Matthew W. Scott ${ }^{1}$, Paul J. Sylvester ${ }^{2}$, and Derek H. C. WILTON ${ }^{1}$}

1. Canada-Newfoundland and Labrador Offshore Petroleum Board, St. John's, Newfoundland and Labrador A1C 6H6, Canada g

2. Department of Geosciences, Texas Tech University, Lubbock, TX 79409-1053, USA

A number of hydrocarbon discoveries have been made recently in the Flemish Pass Basin and Central Ridge, offshore Newfoundland, Canada, but only limited geological information is available. This provenance study is aimed at providing new mineralogy, geochronology, and geochemistry datasets on Upper Jurassic source and reservoir rocks from this area. The primary goal was to determine the provenance and paleodrainage patterns of the Upper and Lower Kimmeridgian Source Rock members, and Upper and Lower Tempest Sandstone Member reservoirs of the Rankin Formation. The provenance results thus help define where thicker sequences of hydrocarbon source rocks and reservoir units are located in the region.

Sixty lithology samples from conventional core and cuttings of both mudstones and sandstones were acquired, processed, and analyzed from four wells: Baccalieu I-78, Panther P-52, South Tempest G-88, and Lancaster G-70. A combination of detrital zircon $\mathrm{U}-\mathrm{Pb}$ geochronology, whole-rock geochemistry, and SEM-MLA analysis of heavy mineral concentrates were used to decipher provenance. Based on these data, the Upper and Lower Kimmeridgian Source Rocks are composed of detritus from the Avalon Zone and Central Mobile Belt, along with the underlying basement. These source regions are not overly indicative of a drainage orientation, as they exist both northeast and west of the study area. Therefore, it is possible that detritus would have been derived from both areas, and thicker sequences of these units are likely to be present in either the western, or, northeastern portions of the Flemish Pass Basin and Central Ridge. The Upper and Lower Tempest Sandstone members are characterized by material from the Avalon Zone; however, some of the detritus in these units is interpreted to be derived from Iberia to the east. Thus, the Tempest Sandstone members were likely derived at least in part from the east, which infers thicker sequences of this unit are likely present towards the eastern edges of the Central Ridge and Flemish Pass Basin.

Knowledge of where these units are thickest should be an important consideration for petroleum exploration in the region. In addition, the Upper Tempest Sandstone contains Mesozoic zircon grains, which constrain the depositional age of this unit, and not found in samples from the other units.

Late Jurassic to Early Cretaceous depositional systems and sequences, Flemish Pass extensional basin, offshore Newfoundland, Canada

\section{Anthony ScotT ${ }^{1}$, Stephen Schwartz ${ }^{1}$, Xavier M. T. van Lanen ${ }^{1}$, Allard W. Martinius ${ }^{2}$, and James A. MACEACHERN $^{3}$ \\ 1. Equinor ASA Canada Ltd., 2 Steers Cove, St. John's, Newfoundland and Labrador A1C 6J5, Canada 9 \\ 2. Equinor ASA Norway Ltd., Trondheim 4035, Norway 9 3. ARISE, Department of Earth Sciences, Simon Fraser University, Burnaby, British Columbia V5A 1S6, Canada}

The Flemish Pass is a Mesozoic extensional basin located $500 \mathrm{~km}$ offshore of Newfoundland, containing oil discoveries in multiple stacked reservoirs. Recent wells (2013-2017) drilled into the Bay du Nord and Baccalieu discoveries retrieved cores that were logged sedimentologically and ichnologically to understand Late Tithonian to Early Berriasian depositional systems and to build a sequence stratigraphic framework. Micropaleontological and petrological data were also utilized to refine these interpretations. 
Late Tithonian reservoirs in Bay du Nord are interpreted as fifth- to sixth-order composite sequences. Fluvial channel sandstone complexes with erosional bases represent broad, shallow lowstand incised fluvial valley fills $(5-7 \mathrm{~km}$ wide and 15-40 $\mathrm{m}$ thick) overlying subaerial unconformities. Sandstones are sublitharenites to feldspathic litharenites with siliciclastic metasedimentary and reworked carbonate rock fragments. Lower delta plain deposits are overlain by delta-front heterolithic intervals, recording transgression in a hypoxic, inner neritic environment. By contrast, outer shelf mudstones, consisting of coccolithophoroids, with quartz grains and minor illite and mica, pass upwards into prodeltaic heterolithic intervals, correspond to highstand system tracts in an oxic, inner neritic environment. The sandstones were sourced from sedimentary and metasedimentary rocks with a significant proportion of limestone lithic fragments lying to the south and west of Bay du Nord, which were fed into a low gradient basin with minor topographic relief.

The Early Berriasian reservoirs at Baccalieu consist of progradational cycles $15-50 \mathrm{~m}$ thick. Outer shelf calcareous mudstones, overlain by prodeltaic silty mudstones and delta-front structureless sandstones, were deposited in an oxygenated inner to middle neritic environment, largely by hyperpycnal flows, and represent a late lowstand/early transgressive sequence set. Early Berriasian sandstones are litharenitic with metamorphic rock fragments. Mudstones are illite-mica with minor intercalated quartz grains. The sediments represent localised lowstand shelf-type deltas ( $\sim 10 \mathrm{~km}$ wide fans) with hyperpycnal flows building out onto a steeper, narrow basin with sediment sourced from the east. The changes in paleoenvironment, depositional systems, and provenance during the Early Berriasian are linked to fault movement and generation of localized accommodation space along the margins of the Flemish Cap.

\section{Rift to drift evolution and hyper-extension in the North Atlantic - insights from a super-regional approach}

\footnotetext{
Ian R. SharP ${ }^{1}$, Simon Higgins ${ }^{1}$, Mark ScotT ${ }^{1}$, Ulrike

Freitag $^{1}$, Catherine Allsop ${ }^{2}$, Kane Karla ${ }^{2}$, Adam Sultan $^{2}$, Paul DoubledaY ${ }^{2}$, Chris Leppard ${ }^{2}$, John CODY $^{3}$, GeOFF RaIt ${ }^{3}$, Simon Haynes ${ }^{2}$, BJORN Ove TORUdbakken ${ }^{4}$, Tore HANSEN ${ }^{4}$, Vidar Fossli ${ }^{4}$, AND ADAM CHENG ${ }^{4}$

1. Equinor ASA, Sandsliveien 90, Bergen, 5020 Norway 9 2. Equinor UK, 1 Kingdom Street, London W2 6BD, United Kingdom $\mathbf{g}$

3. Equinor Canada, 3600, 308, 4 Avenue SW, Calgary, Alberta T2P 0H7 Canada 9

4. Equinor ASA, Oslo, Norway
}

Unravelling the rift to drift evolution of the North Atlantic is key to place exploration opportunities within a super-regional basin evolution context. This is particularly the case for understanding the deposition, distribution, and preservation of key source rock intervals. In this contribution, we outline the results of a regional exploration project addressing the plate tectonic and tectonostratigraphic evolution of the greater North Atlantic Conjugate Margin (NACM). The study focused on documenting the range of end member basins/margins developed in the NACM, from "failed" inboard rift systems such as the Porcupine, Flemish, Orphan, Jean d'Arc, Lusitanian, and Galicia basins, to "successful" rift to drift margins, such as the Newfoundland and Iberian Atlantic margins. A unifying present-day observation based Structural Domain classification scheme is outlined and evolutionary models presented that could account for the observational domains.

Two key themes control basin evolution, structural style, and eventual breakup in the NACM. The first is the role of structural inheritance (Caledonide-Variscan fabrics and basement terranes) that impart a first order control on basin and fault segmentation, rift tip locations, structural style, and early phases of basin fill (Triassic and older). The second is polyphase/pulsed extensional events, i.e. "multi-rifting", from Permian-Triassic extensional collapse and distributed rifting, Early Jurassic passive subsidence, Middle Jurassic uplift and volcanism, Late Jurassic rifting - ranging from decoupled rift climax half graben development (largely Oxfordian-Kimmeridgian) through to rift axis migration/ focusing, fault coupling and the onset of hyperextension (largely Tithonian). The final stages of basin development can include eventual mantle exhumation, volcanic addition and, along "successful" rift to drift margins, eventual ocean crust emplacement. A further complicating post-breakup modifier in the European basins is Alpine inversion, which has a marked impact on prospectivity. During this contribution, we will show observations from a range of NACM basins, including Porcupine, Flemish Pass, Orphan, Salar, and Iberia, and present a unifying geodynamic rift to drift model.

Automated quantitative evaluation of minerals in the Kimmeridge Clay Formation (Dorset, United Kingdom)

\author{
Ricardo L. Silva ${ }^{1,2}$, Stephen P. Hesselbo ${ }^{3}$, AND R. \\ Celestino $^{3}$ \\ 1. Basin and Reservoir Lab, Department of \\ Earth Sciences, Dalhousie University, Life Sciences Centre, \\ Halifax, Nova Scotia B3H 4R2, Canada g \\ 2. Marine and Environmental Sciences Center (MARE), \\ University of Coimbra, Rua da Matemática, $n^{\circ} 49$,
}




\section{4-517 Coimbra, Portugal g \\ 3. Camborne School of Mines and Environment and \\ Sustainability Institute, University of Exeter, Penryn Campus, Penryn, Cornwall TR10 9FE, United Kingdom}

Despite decades of research, the palaeoenvironmental and sedimentological controls leading to the unusual organic matter (OM) contents of the Kimmeridgian-Tithonian Kimmeridge Clay Formation (KCF) and contemporaneous successions around the Atlantic margins are still debated. Several studies conducted in the Dorset area of southern England, the type locality of the KCF, demonstrated the connection between OM content, depositional conditions, and astronomical parameters (eccentricity, obliquity, and precession).

The most recent cyclicity studies of the KCF conducted at Dorset use the datasets collected between 1996 and 2001 by the NERC-funded Rapid Global Geological Events (RGGE) project. These datasets, coupled with GTS2004 ages are, until today, the basis to investigate astronomical-dependent sedimentary cyclicity (including the organic-rich intervals) and build astronomically-based chronologies for the KCF and the Kimmeridgian-Tithonian time interval. New developments in analytical techniques and the recently updated numerical ages for the Kimmeridgian-Tithonian open the opportunity to, 20 years later, revisit the data collected by the RGGE project.

Our first step in this new project was to perform a pilot study focusing on automated quantitative evaluation of minerals (QEM) in several mudstone, limestone, and dolostone lithofacies from the KCF outcrop at Kimmeridge Bay (Dorset, UK). QEM uses automated image analysis combining backscatter and energy-dispersive X-ray signals to identify minerals. This method generates a complete mineral identification of the studied sample and a detailed mineralogical dataset for the studied interval, potentially addressing issues such as sedimentary provenance (heavy minerals), diagenesis (chemical variation of mineral species), and climatic variation (clay mineral assemblages).

Jurassic environments (Iroquois Formation) of the Scotian Basin (Nova Scotia, Canada)

\section{Ricardo L. Silva, Maya Soukup, and Grant D. Wach}

1. Basin and Reservoir Lab, Department of Earth Sciences, Dalhousie University, Life Sciences Centre, Halifax, Nova Scotia B3H 4R2, Canada

The Lower?-Middle Jurassic core 8 from the Mohican I-100 well was analyzed to gain a better understanding of Early and Middle Jurassic carbonate and evaporitic environments along the central Atlantic margin during the formation of the proto-Atlantic Ocean. The studied core is part of the Iroquois Formation (Lower?-Middle Jurassic), in the offshore Scotian Basin.

The Mohican I- 100 core 8 consists mostly of dolostone and dolomitic limestone, with obstruction of micro-sedimentary features common throughout most thin sections. Core 8 is interpreted to correspond to alternating intervals of arid and semi-arid/coastal plain/marginal marine sabkha? deposits with restricted lagoonal (marine influenced) deposits. Microbial mat/tidal flat facies alternating with anhydrite is described here for the first time for this core. Overall, base level changes lead to the transition from a restricted setting into a higher energy, less restricted environment, with semiarid coastal plain intervals appearing infrequently.

Lower Jurassic organic matter preservation events in the Central and North Atlantic conjugate margins

Ricardo L. Silva ${ }^{1,2}$, Grant D. WACH ${ }^{1}$, Luís V. Duarte ${ }^{2}$, Juan J. GómeZ ${ }^{3}$, Stephen P. Hesselbo ${ }^{4}$, Driss Sadki ${ }^{5}$, JoÃo G. Mendonça Filho ${ }^{6}$, Bruno Rodrigues ${ }^{2}$, AND DARRAGH O'CONNOR ${ }^{1}$

1. Basin and Reservoir Lab, Department of Earth Sciences, Dalhousie University, Life Sciences Centre, Halifax, Nova Scotia B3H 4R2, Canada g

2. MARE - Marine and Environmental Sciences Center, Departamento de Ciencias da Terra, University of Coimbra, Rua da Matemática, n 49, 3004-517 Coimbra, Portugal g 3. Stratigraphy Department, Geological Science Faculty, University Complutense Madrid, José Antonio Novais, 12, $3^{a}$ planta, $d p .14 A, 28040$ Madrid, Spain $\mathbf{g}$ 4. Camborne School of Mines and Environment and Sustainability Institute, University of Exeter, Penryn Campus, Penryn, Cornwall TR10 9FE, United Kingdom g

5. Moulay Ismaïl University, Faculty of Science, BP. 11201 Zitoune, Meknes, Morocco 9

6. Departamento de Geologia, Instituto de Geociências, Universidade Federal do Rio de Janeiro, Av. Athos da Silveira Ramos, 274-Cidade Universitária-Ilha do Fundão, Rio de Janeiro-RJ, 21044-020, Brazil

Along the Central and North Atlantic conjugate margins, Lower Jurassic sedimentary successions include several organic-rich intervals with source rock potential. These units comprise the Sinemurian to Pliensbachian organic matter preservation intervals (OMPIs), and the Toarcian Oceanic Anoxic Event (T-OAE). The deposition of these organicrich intervals was modulated by global paleobiological and paleoenvironmental changes and major perturbations of the carbon cycle. However, the local record of these events, 
and production and preservation of organic matter, depends on local paleogeography, paleoclimate, and depositional setting. The objective of our study is to: a) construct a detailed and accurate temporal and geographical frame of Lower Jurassic organic-rich facies occurrences and their main characteristics for the Lower Jurassic at a global scale, and b) use this framework to predict the occurrence of these intervals in the offshore Scotian Basin (Atlantic Canada, Central Atlantic). To accomplish our goals, we evaluated and reinterpreted most of the existing and available organic geochemistry datasets for the Lower Jurassic and conducted several novel geochemical studies performed on selected locations from Spain, Portugal, and Morocco (outcrops).

\section{High pressure situations: understanding reservoir compartmentalization in the Sable Sub-basin}

\section{Carla H. Skinner ${ }^{1}$, Grant D. Wach ${ }^{2}$, and Juan C. WONG $^{2}$ \\ 1. Shell Canada Limited, 400 4th Avenue SW, Calgary, Alberta T2P 5H5, Canada 9 \\ 2. Basin and Reservoir Lab, Department of Earth Sciences, Dalhousie University, Life Sciences Centre, Halifax, Nova Scotia B3H 4R2, Canada}

The Scotian Margin pressure systems have been extensively studied to understand the mechanisms and timing of excess pressure generation and dissipation, with a strong focus on the Sable Sub-basin. Fluid pressures are observed in Jurassic and Early Cretaceous reservoirs, where they increase with depth in unpredicted increments from hydrostatic to immense excess pressure. This study examined whether the excess pressure distribution is controlled by the reservoir connectivity, which is ultimately a function of permeability. Pressure distribution was investigated with a sub-regional 3D static reservoir model for five gas fields: South Venture, Venture, Arcadia, Citnalta, and Uniacke. The model was built by interpretation of a 3D seismic volume integrated and calibrated with data from 27 wells. The model was populated with excess pressure data and upscaled lithologies interpreted from wireline logs and well tests.

Excess-pressured sections are lithified with thin intraformational seals and high net-to-gross ratios of porous to tight sandstones, shales, and low permeability limestones. It is difficult to justify current excess pressure without regional late hydrocarbon generation (or another late pressure source) given micro-nano Darcy flow across thin imperfect seals that should allow for pressure equilibration over at most several million years. Hydrocarbon generation during the Cretaceous was cited as a pressure source supported by basin modelling results. Pressure and fluids are interpreted to be currently entering the system by ongoing generation of hydrocarbons based on recent thermal modelling of the South Venture O-59 well.

A similar arrangement of reservoir connectivity and pressure distribution is observed in all the fields, although the units' ages evolve due to progradational advance of the shelf and progressive formation of expansion trends. Expansion trends are isolated, high accommodation space depocentres formed in the hanging walls of down-to-basin listric faults. These faults created low-relief, hanging wall, fault-bend folds - the main hydrocarbon traps of the subbasin.

In the deep section, where reservoirs are stratigraphically and structurally isolated, the fluids and pressures are interpreted to be actively dissipating by mechanical leak. In the intermediate section, pressure equilibration within pressure cells occurs where the displacement of minor crestal faulting exceeds the thickness of minor intra-formational seals allowing for "stair stepping" up juxtaposed permeable units. In the shallow section, which is above the listric fault system, the reservoirs are contiguous and hydrostatically pressured. The model supports that reservoir connectivity, therefore permeability, is the primary control on the excess pressure distribution, and supported by late to ongoing hydrocarbon generation.

\section{DSDP 603B and BR 93-1: examination of clues to the possible presence of petroleum system(s) in the USA Central Atlantic OCS}

\section{Dominic Smith and Paul J. Post}

U.S. Department of the Interior, Bureau of Ocean Energy Management, Office of Resource Evaluation, 1201 Elmwood Park Blvd., New Orleans, Louisiana 70123-2394, USA

Deep Sea Drilling Project (DSDP) 603B drilled during 1983 in $15201 \mathrm{ft}$. (4633 m) of water about $270 \mathrm{mi}(440 \mathrm{~km})$ east of Cape Hatteras, NC, reached a total depth (TD) of $20402 \mathrm{ft}$. (6218 m) in Early Cretaceous (EK) Berriasian marl and limestone. It encountered thin, variable, immature source rocks of Late Cretaceous (LK) and EK age with total organic carbon (TOC) content of 0.57-20.4\%. Maturation pathways indicate Types II/II-III and III kerogens. An EK (Valanginian-Barremian age) turbidite $\sim 980 \mathrm{ft}$. (299 m) thick, $45 \%$ being siltstone and sandstone, topped by $\sim 130 \mathrm{ft}$. $(39 \mathrm{~m})$ of clean, uncemented sands of ?Barremian-Aptian age deposited in a lowermost slope-abyssal setting was encountered. Heavy mineral analysis suggests a Central Appalachian provenance.

In 1984, Shell et al. drilled Baltimore Rise (BR) 93-1 well approximately $265 \mathrm{mi}(430 \mathrm{~km})$ northwest of DSDP 603B (ca. $80 \mathrm{mi} / 130 \mathrm{~km}$ east of the Maryland coast). Targeting 
a large, faulted structure of the Gemini Fault System, in $5017 \mathrm{ft}$. $(1529 \mathrm{~m})$ of water, the well reached a TD of 17 $740 \mathrm{ft}$. (5407 m) in EK Valanginian-Berriasian limestones and shales. TOCs in the oil window, below $13700 \mathrm{ft}$. (4175 $\mathrm{m}$ ), were $0.15-2.19 \%$, averaging $1.3 \%$. Types III (gasprone) and IV (inert) kerogens dominate. There were no significant hydrocarbon shows. Modelling indicates little hydrocarbon generation/expulsion. Anticipated shelfmargin delta reservoir sandstones updip from the turbidites in DSDP 603B were not encountered. BR 93-1 penetrated $\sim 6234 \mathrm{ft} .(1900 \mathrm{~m})$ of Barremian shale interbedded with thin limestones and siltstones. These strata were primarily deposited in shallow (inner shelf, $<100 \mathrm{ft}$. $/ 30 \mathrm{~m}$ ) paleowater depths (WDs), although some paleo suggests deep outer shelf WDs of $\sim 600 \mathrm{ft}$. / $182 \mathrm{~m}$. The low petroleum potential of the thermally mature kerogens in the Cretaceous shales and marls of BR 93-1, and the lack of reservoirs resulted in a dry hole.

Between BR 93-1 and DSDP 603B, heat flow and sediment thickness isopachs suggest mature source rocks may occur. EK paleoslope and basin-floor channels, conduits for sediment transport to the area of DSDP 603B can be interpreted on the single, strike-oriented seismic line between the wells. Seismically well-imaged paleoslope channels occur farther northeast. The possible existence of source and reservoir suggest petroleum system(s) may occur in this large, unexplored area. The BOEM recognized this potential, delineating the Cenozoic-Cretaceous and Jurassic Paleo-Slope Siliciclastic Core and Extension Assessment Units, with total mean undiscovered technically recoverable resources of approximately 5.6 billion barrels of oil equivalent.

\section{Old wells - new plays: evaluating previous drilling results to guide current and future exploration from offshore Argentina}

David J. A. Spofforth, Jordan Walker, Alex Reid, Shona Culwick, and Sonia Williams

CGG Multi-Client \& New Ventures (GeoSpec), Tyn-y-Coed, Pentywyn Road, Llandudno LL30 1SA, United Kingdom

The opening of the South Atlantic generated a number of prolific hydrocarbon-bearing basins in both South America and West Africa, many of which have been extensively exploited. The notable exception to this is the continental shelf of Argentina. Here, with the exception of the Austral and San Jorge Basins, drilling has been limited in the Colorado, Malvinas, Rawson, Salado and San Julian Basins. Despite some encouraging results and all elements of the petroleum system having been proven, exploration of these basins had tailed off by the early 1990s. Now, oil industry interest is once again beginning to focus on this underexplored region, no doubt encouraged by the potential for hydrocarbons plays at a number of different stratigraphic levels. As part of this new wave of exploration we have generated an extensive database of enhanced legacy seismic and well data, supplemented by regional datasets from analogous basins. Examination of this integrated database has led to a more thorough understanding of the key geological risks; reservoir presence and hydrocarbon charge; as well as the commercial results of previous exploration efforts. Critically, this includes placing drilling results in their historical context with respect to the data used to identify prospects and plays, so that the "fairness" of each well test can be properly evaluated. From this database review, and by using analogues from successful wells drilled in the Austral and San Jorge Basins, as well as elsewhere, we have distinguished the key proven petroleum plays from those which require further analysis, ultimately helping to guide future exploration offshore Argentina.

Fluids implicated in hydrocarbon migration: Identifying the perpetrators in rifted margins

\footnotetext{
Holly J. Stein ${ }^{1,2}$ AND Judith L. HanNaH ${ }^{1,2}$

1. AIRIE Program, Colorado State University, 1482 Campus Delivery, Fort Collins, Colorado 80523-1482, USA g

2. Centre for Earth Evolution and Dynamics (CEED), University of Oslo, P.O. Box 1028, 0316 Oslo, Norway

Hydrocarbons travel together with aqueous fluids as they are expelled from source rocks, migrate, and accumulate in reservoirs. Simple models suggest that aqueous fluids are derived from the source rocks themselves and/or connate waters in permeable rocks along the migration pathway. Isotopic tracers offer a test for such models. Using the osmium isotope tracer, we show that deep faults dissecting the crust in rift environments tap primitive fluids, affirming the importance of these structures in localizing oil fields and challenging long-standing models for hydrocarbon maturation and mobility.

Rhenium (Re) and osmium (Os) comprise a parentdaughter isotopic pair, offering both geochronology and an isotopic tracer. ${ }^{187} \mathrm{Re}$ decays to ${ }^{187} \mathrm{Os}$ with a half-life of 41.6 $\mathrm{Ga}$. Despite the long half-life, commonly high Re/Os ratios produce enough radiogenic Os for precise measurements even in very young rocks. Because Os is compatible in mantle mineral assemblages, whereas Re is mildly incompatible, Re/ Os ratios in the crust are far higher than those in the mantle. Over time, therefore, mantle ${ }^{187} \mathrm{Os} /{ }^{188} \mathrm{Os}$ remains low $(\sim 0.13$ today), while crustal ${ }^{187} \mathrm{Os} /{ }^{188} \mathrm{Os}$ may range from $\sim 1$ (e.g.
} 
modern seawater) to extreme values in Re-rich materials. Organic-rich sedimentary rocks typically have ${ }^{187} \mathrm{Re} /{ }^{188} \mathrm{Os}$ ratios in the 100 s to $1000 \mathrm{~s}$, generating ${ }^{187} \mathrm{Os} /{ }^{188} \mathrm{Os}$ ratios of 0.5 to $>5$ over time. Many oils derived from these source rocks have broadly similar ratios, suggesting minimal elemental or isotopic fractionation during maturation and migration.

Among other localities, the AIRIE Program has analyzed a variety of oils from the rifted Norwegian Continental Shelf. In certain fields, measured ratios for both ${ }^{187} \mathrm{Re} /{ }^{188} \mathrm{Os}$ and ${ }^{187} \mathrm{Os} /{ }^{188} \mathrm{Os}$ are extremely low $(<10$ and $<0.2$, respectively). Such data interrogate our present thinking on oil generation. A chapter in hydrocarbon generation models must include fluids carrying primitive (mantle-derived) Os interacting with kerogen and/or its expelled products. That is not to say oil is abiogenic, but that oil generation processes go beyond burial of sedimentary rocks with their connate basin fluids. We have coupled case studies with experimental work to show the effect water-oil interaction on different oils. Importantly, isochron ages for asphaltene-crude-maltene triplets are preserved whereas the Os tracer identifies fluids involved in hydrocarbon migration history.

Exploration creativity in the golden age of Super Basins

Charles A. Sternbach

Star Creek Energy, 25801 Stockdick School Road, Katy, Texas 77493, USA

Many Super Basins were thought to be on their way out of sustainable production. Key enablers that have made possible old basins reaching new production peaks include hydraulic fracturing in horizontal wells and enhanced seismic imaging. Each basin has unique geoscience architecture. A common scheme includes multiple rich source rocks located beneath thick sedimentary packages containing many reservoirs and seals.

Onshore basins like the Permian (in Texas and New Mexico) are dominated by perfecting multi-lateral multidirectional drilling, finding the right fluid mix, varying hydraulic fracture stages, prop materials, and well length in the realization of unconventional resources. These basins are benefiting from multi generations of engineering refinements and breakthroughs.

Other basins, many offshore, are benefiting from improved seismic imaging to unlock deeper or hidden basins, sedimentary packages previously obscured for various reasons. Many of the new resources are being found below salt or around basement highs. Examples include GOM, Brazil, and the European North Sea. Some basins benefit from both engineering and seismic. In all cases, understanding the geoscience architecture is key to success. This is also important in conjugate margins plays.

\section{The Carboniferous (Namurian) Clare Shale: a possible petroleum system in western Ireland}

\section{Christopher S. Swezey ${ }^{1}$, John T. Haynes ${ }^{2}$ and Paul C. HACKLEY $^{3}$ \\ 1. U.S. Geological Survey, 12201 Sunrise Valley Drive, MS 926A, Reston, Virginia A 20192, USA g \\ 2. James Madison University, Department of Geology and \\ Environmental Science, 395 S. High Street, MSC 6903, Harrisonburg, Virginia 22807, USA g \\ 3. U.S. Geological Survey, 12201 Sunrise Valley Drive, MS 956, Reston, Virginia 20192, USA}

The Carboniferous (Namurian) Clare Shale is a ca. 35-280 m-thick shale that forms the basis of a possible petroleum system in the Shannon Basin (Clare Basin) in western Ireland. The Clare Shale lies above Carboniferous (Viséan) limestone, and is overlain by Carboniferous (Namurian) sandstone and mudstone (Ross Formation, Gull Island Formation). Analyses of five Clare Shale outcrop samples revealed total organic carbon (TOC) values ranging from 0.29 to $27.66 \mathrm{wt} . \%$, and mean vitrinite reflectance (Ro) values ranging from 4.21 to $4.59 \%$. Most of the organic matter is Type III (vitrinite, inertinite). The outcrop samples are thermally overmature with respect to petroleum generation, but to the north (away from the Variscan front/ Iapetus suture) one would expect lower thermal maturity, with the shale eventually going into the gas window and then the oil window. Hypothetical reservoir intervals for the petroleum system include the Clare Shale itself, overlying Upper Carboniferous sandstones, and underlying Lower Carboniferous limestone. Structural traps (anticlines) should be more common near the Variscan orogenic front/ Iapetus suture, and stratigraphic traps should be more common farther to the north away from the Variscan front. Potential reservoir seals include the Clare Shale itself and other mudrock units of the overlying siliciclastic strata. With respect to stratigraphic context, the Clare Shale is similar to the Ordovician Utica Shale and Devonian Marcellus Shale of North America in that the Clare Shale occurs near the base of a succession of siliciclastic strata that accumulated during a 10-40 million year interval associated with an orogenic event.

A new kinematic tool for petroleum system modeling in structurally complex margins: application to the Chidley Basin, Labrador, Canada

Alcide Thébault ${ }^{1}$, Erwan Le Guerroué ${ }^{1}$, Pierre- 
Yves Filleaudeau ${ }^{1}$, Guillermo Perez-Drago ${ }^{1}$, Luca Micarelli $^{1}$, Paul Jermannaud ${ }^{1}$, And Marie Callies ${ }^{1}$

Beicip-Franlab, 232 av. Napoléon Bonaparte, Rueil-Malmaison, 92500, France

Today, petroleum system modeling recognized as a critical step in exploration workflows. However, even areas considered easily modelled, such as passive margins, can present structurally complex features that classic basin modeling tools do not accurately manage. These complex elements such as listric faults or compressive deformation fronts will have an impact on hydrocarbon migration and trapping through time and require more accurate modeling approaches integrating active faulting, folding and synchronous fluid flow. The basin burial history and lateral extension that influence global heat flow and pressure regimes also should be handled in order to improve the classical vertical backstripping approach.

An application case from the Chidley Basin, offshore Newfoundland, Canada is illustrated here by taking into account the Cretaceous rifting history. High sedimentation rates are recorded throughout the Cenozoic resulting in undercompacted sediments and potential high overpressures. Main attention is directed towards the resulting Oligocene gravitational system over a Paleocene decollement generating rollover and toe thrust anticlines. This approach allows testing potential hydrocarbon migration together with ongoing deformation.

This work introduces a new 2D kinematic tool $\left(\right.$ KronosFlow $\left.^{\text {TIN }}\right)$ specifically designed to meet this objective. Starting from a present day section with balanced interpretations, 30 restoration steps were defined to account for source rock, reservoir, and seal layers within the stratigraphic section as basin modeling requires a detailed kinematic tectono-stratigraphic architecture. This kinematic restoration is then gridded, creating a mesh in which each cell deformation is tracked through time, thus preserving 2D mass balance. Forward basin modeling tools (heat transfer, pressure, hydrocarbon generation, migration and accumulation) are then run using this mesh, accounting for horizontal and vertical displacement and burial history. This original modelling approach allows the implementation of numerous faults object in which gouge and damage zones properties are simulated through time. This realistic structural framework and kinematic restoration is used to test overpressure distribution in response to fault behavior as compartmentalization affects migration pathways and hydrocarbon charge and quality. Several scenarios are elaborated renewing exploration prospectivity in the Chidley Basin.

\section{Sources, sand provenance and supply to North Atlantic margin basins during the Early Cretaceous}

Shane Tyrrell ${ }^{1,2}$, Aron Barry ${ }^{1}$, Kerryming SUN ${ }^{1}$, David

CheW $^{3}$, Aoife Blowick ${ }^{1,2}$, Jess FrankLiN ${ }^{1,2}$, Martin

NAUton-FourteU ${ }^{1,2}$, BéBhINN ANDERs ${ }^{1}$, ANDrew

Morton $^{4,5}$, Xavier Monteys ${ }^{6}$, Nathan Cogné,

Peter D. W. Haughton ${ }^{7}$, J. Stephen Daly ${ }^{7}$, and Patrick M. Shannon ${ }^{7}$

1. Earth and Ocean Sciences and Sediment Origins Research Team (SORT), School of Natural Sciences, National University of Ireland Galway, University Road, Galway, Ireland 9

2. Irish Centre for Research in Applied Geosciences

(iCRAG), School of Natural Sciences, National University of

Ireland Galway, University Road, Galway, Ireland 9

3. Department of Geology and Irish Centre for Research in

Applied Geosciences (iCRAG), Trinity College, College Green, Dublin 2, Ireland 9

4. HM Research Associates, Giddanmu, St Ishmaels, Haverfordwest, Pembrokeshire SA62 3TJ, United Kingdom 9

5. CASP, University of Cambridge, 181a Huntingdon Road,

Cambridge, Cambridgeshire CB3 ODH, United Kingdom 9

6. Geological Survey of Ireland, Beggars Bush, Haddington Road, Dublin 4, Ireland g

7. UCD School of Earth Sciences and Irish Centre for Research in Applied Geosciences (iCRAG), University College Dublin,

Dublin 4, Ireland

The northeast Atlantic margin comprises underexplored sedimentary basins and poorly characterized submarine basement highs (e.g., Porcupine High). The basement highs are important as constraining their age and affinity will help identify onshore correlatives on both margins and provide clues as to the prerift configuration of the region. In addition, on-going provenance work has suggested that they have influenced the supply of sediment to basins since the Late Paleozoic. The composition of these basement areas, therefore, is a possible first-order control on the quality and distribution of potential reservoir sandstones in adjacent sedimentary basins.

The aim of this study was to: (1) develop a better understanding of the age and crustal affinity of the Porcupine High; and (2) determine sedimentary dispersal pathways from the high, and from surrounding areas, during the early Cretaceous. In order to achieve this, a multi-proxy geochemical approach was implemented which combined petrography, heavy mineral analysis, in-situ isotopic analysis of individual sand components, and thermochronology.

Analysis of samples retrieved from the Porcupine High has indicated a complex geology, including Archaean to Paleoproterozoic gneisses, Mesoproterozoic orthogneiss, a Neoproterozoic metasedimentary succession, and late 
Caledonian igneous rocks. $\mathrm{Pb}$ isotopic K-feldspar and $\mathrm{U}_{-}$ $\mathrm{Pb}$ zircon analyses suggest these rocks have close affinities with the Lewisian Complex of northwest Scotland and its equivalents, regional Grenvillian crust, and with the metasedimentary Dalradian Supergroup. The burial history is equally complex, with differential uplift indicated across the high. This increasingly detailed view of Porcupine High geology has allowed sedimentary supply from this area to be assessed for the first time.

Lower Cretaceous sands and sandstones were sampled from wells in the Erris, Porcupine and Goban Spur basins. $\mathrm{U}-\mathrm{Pb}$ zircon ages and $\mathrm{Pb}$ isotopes in $\mathrm{K}$-feldspar suggest that older, Lewisian-type, sources dominate supply to the Erris Basin, while Grenvillian-type and younger grains dominate the sediment delivered to the Porcupine Basin. The presence of Grenvillian feldspar and zircon in both basins, paired with the absence of Lewisian-type detritus in the Porcupine Basin, suggests there is a significant drainage divide across the Porcupine High. This divide is likely oriented NE-SW, potentially aligned with significant regional lineaments, and appears to be buffering the delivery of sand southward during the early Cretaceous.

\section{Marine influence and other controls on organic matter preservation in Langsettian, Carboniferous lacustrine source rocks of the Joggins Formation, Nova Scotia, Canada}

\section{G. Todd Ventura ${ }^{1}$, R. Andrew MacRae ${ }^{1}$, Yaisa Owino ${ }^{1}$, AND MATtheW R. STIMSON ${ }^{1,2}$ \\ 1. Department of Geology, Saint Mary's University, Halifax, Nova Scotia B3H 3C3, Canada g \\ 2. Steinhammer Paleontology Laboratories, New Brunswick Museum, Saint John, New Brunswick E2K 1E5, Canada}

The Joggins Fossil Cliffs of Nova Scotia, Canada, represents one of the most continuous exposures ( 4.4 $\mathrm{km}$ ) of a Carboniferous coal basin in the world. Part of this succession is represented by the Joggins Formation, which extends for $2.8 \mathrm{~km}$ along the coastal section of the Cumberland Sub-basin. Subsidence from salt-withdrawal deeper in the basin resulted in rapid accommodation to produce 14 well-characterized parasequences. Many of these repeated transgression events, which are composed of fluvial/deltaic mudrocks overlain with bioturbated paleosols and bituminous coal measures, began with the deposition of carbonaceous-rich, freshwater limestone units marking the maximum flooding surface of the shallowing upward interval.

Although the Joggins Formation was deposited $~ 2500$ $\mathrm{km}$ inland from the Tethys paleo-shoreline, the basal section contains evidence of marine incursions. This study investigates whether geochemical data can (1) help resolve the temporal extent of these events, and (2) determine what effects marine conditions had on the type and preservation of the organic matter in these prospective source rocks.

Specific emphasis is focused on resolving whether sulfurization of organic matter (SOM) was involved in kerogen formation. This early diagenetic process leads to selective preservation of hydrogen-rich, labile organic matter and thus affects the quality, and to a lesser degree, the richness of organic matter preserved in source rocks. SOM can lead to petroleum generation at shallower burial depths because the less stable sulfur-carbon bonds break at lower temperatures. Forty samples, spanning seven wellcharacterized parasequences extending from the base to the top of the formation, are being analyzed for transition metal and elemental sulfur concentrations using portable X-Ray Fluorescence.

These data will be compared against bulk pyrolysis measurements to evaluate factors controlling the richness, quality, and maturity of the host rock's organic matter. Additional geochemical constrains are also being provided via biomarker-based paleoecological reconstruction using comprehensive two-dimensional gas chromatography. The results of this chemostratigraphic study will be used to calibrate geochemical proxies for the identification of marine influence and SOM in other pre- and postrift basin Carboniferous outcrops and cores in Nova Scotia.

Overview of the petroleum systems of the Central Atlantic Margin

Grant D. WaCh ${ }^{1}$, Ricardo L. Silva ${ }^{1}$, Juan C. WONG $^{1}$, Natasha Morrison ${ }^{1}$, Taylor J. Campbell ${ }^{1}$, Trevor B. Kelly ${ }^{1}$, Carla H. Skinner ${ }^{2}$, Kenneth T. Martyns-Yellowe ${ }^{1}$, Darragh E. O'Connor ${ }^{1}$, Anne C. Hargreaves ${ }^{1}$, Charlie Carlisle ${ }^{1}$, Leslie Eliuk ${ }^{1}$, Xinyue $\mathrm{Hu}^{1}$, Maya Soukup ${ }^{1}$, and Philip Sedore ${ }^{1}$

\author{
1. Basin and Reservoir Lab, Department of \\ Earth Sciences, Dalhousie University, Life Sciences Centre, \\ Halifax, Nova Scotia B3H 4R2, Canada g \\ 2. Shell Canada Limited, 400 4th Avenue SW, Calgary, \\ Alberta T2P 5H5, Canada
}

Understanding basin evolution is crucial to deciphering the petroleum system elements. Controls on sedimentation, environments of deposition and the distribution of organic-rich facies on each of side of the Central Atlantic are dependent upon the evolution of the margins. Coastal exposures of Mesozoic sediments in the Wessex Basin and Channel Subbasin (southern UK), and the Lusitanian Basin 
(Portugal) exhibit striking similarities to reservoir and source rocks in the Canadian offshore region and provide keys to the petroleum systems currently being exploited and explored offshore Atlantic Canada. There are very limited outcrops onshore Canada above the Triassic.

We present an overview from outcrop and subsurface studies of key intervals from the Scotian and Newfoundland margins. On the Eastern Atlantic we examine the Irish, UK, Iberian, and northwest African margins. Basins included in this study are Fundy, Scotian, Orpheus Graben, Jeanne d 'Arc, Slyne, Porcupine, Wessex, Paris, Aquitaine, Lusitanian, and High and Middle Atlas basins and offshore Morocco. The European and Northwest Africa (Morocco) exposures provide key physical controls on conformable and nonconformable stratigraphic surfaces, and a range of reservoir and source rocks deposited in terrestrial through clastic and carbonate shallow-marine environments, to the deep marine. These analog sections, and stratigraphic surfaces, can help predict downdip, updip and lateral potential of the petroleum systems, especially source rock and reservoir. Comparative stratigraphic and petroleum system elements are summarized in normalized stratigraphic charts for the Central Atlantic margin.

Paleogeographic maps demonstrate key stratigraphic intervals. Triassic rift basins along eastern North America were separate but with similar histories of rifting and synrift fill. In the Late Triassic, there were marine incursions of the proto-Atlantic, preserved in cores from the Scotian margin. The Early Jurassic marked the end of rifting and a narrow seaway developed between the Scotian and Moroccan conjugate margins. The Eurydice, Iroquois and Mohican formations of the Scotian margin comprise fine grained sediments coeval with interbedded marls, limestones and silty mudstones at Aï Moussa, deposited in anoxic to suboxic environments at the end of the Early Jurassic. This is a key interval of organic rich facies that could introduce new play concepts. In the Late Jurassic, deep marine basins developed with the formation of carbonate platforms and deltas along the margins. From the Cretaceous onward there was normal passive margin development and opening of the seaways adjacent to the North American and European basins.

Jurassic seaways offshore Portugal: subsidence history and early-rift evolution of the North-Central Atlantic

Olivia A. Walker ${ }^{1}$, Tiago M. Alves ${ }^{1}$, Stephen

Hesselbo $^{2}$, Tim ParaOH ${ }^{3}$, And Marianne Nuzzo ${ }^{3}$

1. 3D Seismic Lab, School of Earth and Ocean Sciences, Cardiff University, Main Building, Park Place, Cardiff CF10 3AT, United Kingdom

\author{
2. University of Exeter - Penryn Campus, Penryn, \\ Cornwall TR10 9FE, United Kingdom g \\ 3. British Geological Survey, Science Centre, Keyworth, \\ Nottingham, Nottinghamshire NG12 5GG, United Kingdom g \\ 4. IGI Limited, 2 Hallsannery Farm Cottages, Bideford, \\ Exeter EX39 5HE, United Kingdom
}

The development of Early Jurassic seaways has been recorded along the margins of Northwest Europe, particularly between Iberia and Newfoundland in the form of continental, evaporite, and marine strata spanning the Late Triassic-Early Jurassic. The development of this seaway linked the Central and North Atlantic regions for the first time, but it's true size and palaeo-position is still to be determined. Understanding the establishment and characteristics of these proto-oceanic gateways are key to develop an accurate palaeogeographic setting during the early-rift phase of the North Atlantic.

We will present a series of high-quality regional 2D seismic reflection profiles from offshore Portugal, tied to academic and industry borehole data, to address the development of rift-related units in different Atlantic basins, ultimately leading to the delineation of the Jurassic seaway. Subsidence curves for the Early Jurassic basins show an important synrift period at this stage in the evolution of the seaway, with likely depths of more than $1000 \mathrm{~m}$ being recorded during the Hettangian and Sinemurian. In addition, subsidence curves show that the Lusitanian and Peniche basins were likely part of the same seaway during the early stages of rifting, with important rift-shoulder exhumation occurring between the seaway and the distal margin from Late Jurassic onwards.

The inner Lusitanian Basin and outer Peniche Basin have similar Late Triassic to Early Jurassic characteristics suggesting a co-genetic evolution. Such a character calls for comparisons between other 'similar' basins along the Atlantic margin to be made in order to investigate other active seaways in the Early Jurassic. A similar Early Jurassic seaway existed in the North Sea area, a result of the northward propagation of the rift and multiple transgressive pulses. Differential subsidence between grabens allowed for seawater to inundate basins forming a seaway over sites of previous continental continuity.

In conclusion, the West Iberian and North Sea seaways provided a connection between the Boreal and Tethyan realms, with oxygen isotopes confirming the establishment of seawater exchange by the Pliensbachian. Temporary cessation in water exchanges is nonetheless, expected to induce provincialism of fauna and modification of sediment supply to the depositional basins surrounding the small landmasses present at the time. Future investigation of the 'North Sea' seaway will draw more comparisons with the 'Iberian' one. 


\section{Deep-structure of the East-Limpopo margin, Mozambique (the PAMELA project)}

Louise Watremez ${ }^{1}$, Sylvie Leroy ${ }^{2}$, Elia d'Acremont ${ }^{2}$, Mikael Evain ${ }^{3}$, Angélique Leprêtre ${ }^{3}$, Fanny Verrier ${ }^{3}$, Daniel Aslanian ${ }^{3}$, Nuno Dias 4 , Alexandra Afilhado 5 , Philippe Schnurle ${ }^{6}$, Raymi Castilla 7 , Frank DesPinOIs $^{8}$, AND MARILYNe Moulin ${ }^{9}$

\section{Université de Lille, CNRS, Université Littoral Côte d'Opale,} UMR 8187, LOG, Laboratoire d'Océanologie et de Géosciences, Lille, France

2. Sorbonne Université, CNRS, Institut des Sciences de la Terre de Paris, ISTeP, Paris 6 CNRS, France 9 3. IFREMER, REM/GM/LGS, Centre de Brest, Plouzané 29280, France 9

4. IDL, Instituto Dom Luis, Faculdade das Ciencias de Universidade de Lisboa, Lisboa 1749-016, Portugal g 5. ISEL, Instituto Superior de Engenharia de Lisboa, Lisboa, Portugal g

6. IFREMER, REM/GM/LGS, Centre de Brest, Plouzané 29280, France 9

7. Géo-Energie Suisse, Zürich, Switzerland g 8. Total Exploration et Production, avenue Larribau, Pau 6400, France 9

9. IFREMER, REM/GM/LGS, Centre de Brest, Plouzané 29280, France

The breakup of the Gondwana supercontinent resulted in the formation of the Mozambique passive margin as Africa and Antarctica were separated during the middle Jurassic period. Although plate kinematics during the oceanisation phase are relatively well constrained, the initial fit of Africa and Antarctica, their earliest relative movements, and margin architectures, remain sparsely and/or fully unknown.

The two velocity models, together with the coincident seismic reflection and potential field data, allow (1) to delineate the major crustal domains in the Limpopo region of the Mozambique margin, (2) to constrain velocities and major interfaces down to the Moho discontinuity, and (3) to observe the along-strike variations of the deep structures as well as the amounts of magmatism. Our results show that the Limpopo Mozambique passive margin is characterised by (1) deep basins (up to $12 \mathrm{~km}$ ) controlled by normal faults, and (2) magmatic sills and volcanoclastic material. The necking of the continental crust is narrow and is probably characterised by the presence of magmatic underplating at the base of the crust (upper mantle velocities of $7.3-7.6 \mathrm{~km} / \mathrm{s}$, complex wide-angle Moho reflectivity). We observe some extensional structures in the continental domain along both lines (deep landward-dipping sedimentary basin, graben/ half graben structures). We identify a transitional domain along both lines. However, we believe that this domain is probably oceanic. Oceanic crust is identified along both lines with typical oceanic layering; however, this crust is thicker than normal $(8-9 \mathrm{~km}$ in the north and $10-13 \mathrm{~km}$ in the south), which means a higher than normal magma supply. The oceanic crust is thicker in the south than in the north, implying that magmatism is more intense in the oceanic domain along the southern profile than the northern one.

Deep structure of the Porcupine Basin from seismic refraction data, offshore western Ireland

\author{
Lousie Watremez ${ }^{1}$, Manel Prada ${ }^{2,3}$, Chen Chen ${ }^{4,5}$, \\ Timothy Minshull ${ }^{4}$, Brian O'ReILly ${ }^{2,3}$, Timothy \\ ReSTON $^{6}$, Gerlind Wagner 7 , Viola GaW ${ }^{7}$, Dirk \\ Klaeschen $^{7}$, Patrick ShannoN ${ }^{8,3}$, AND Sergei LebedeV ${ }^{2,3}$ \\ 1. Université de Lille, CNRS, Université Littoral \\ Côte d'Opale, UMR 8187, LOG, Laboratoire d'Océanologie \\ et de Géosciences, Lille, France 9 \\ 2. Dublin Institute for Advanced Studies (DIAS), Geophysics \\ Section, 5 Merrion Square, Dublin 2, Ireland 9 \\ 3. Irish Centre for Research in Applied Geosciences (iCRAG), \\ University College Dublin, Belfield, Dublin 4, Ireland 9 \\ 4. University of Southampton, University Road, \\ Southampton SO17 1BJ, United Kingdom g \\ 5. National Oceanography Centre, European Way, \\ Southampton, Hampshire SO14 3ZH, United Kingdom g \\ 6. School of Geography, Earth and Environmental \\ Sciences, University of Birmingham, Birmingham, \\ West Midlands B15 2TT, United Kingdom g \\ 7. Geomar Helmholtz Centre for Ocean Research, \\ Wischhofstraße 1-3, Kiel 24148, Germany 9 \\ 8. School of Earth Sciences, University College Dublin, \\ Belfield, Dublin 4, Ireland
}

The Porcupine Basin is a V shaped failed rift basin located offshore western Ireland. It was formed during Late Paleozoic to Cenozoic, with the main rifting phase in the Late Jurassic to Early Cretaceous. This basin is characterised by some hyperextension, with lithospheric stretching factors of up to 6 previously estimated in the central part of the basin. Such hyperextension led to uppermost mantle serpentinizsation, which was imaged along a former transect across the basin. A ridge feature is located at the centre of the southern basin, the Porcupine Median Ridge (PMR), and successively interpreted as a volcanic ridge, a tilted block, or a serpentinite mud diapir, with obvious implications on the thermal history of the basin.

We present results from layered travel-time tomographic modelling of five profiles: three across the whole basin, one across the southeastern margin, and one along the centre of the basin that show: (1) variations of thickness 
of the crust, with crustal thinning factors of up to 10 in the southernmost part of the basin; (2) an asymmetry of the crustal structures together with an asymmetry in the uppermost mantle velocities, which highlights the influence of crustal faulting on amounts of serpentinizsation; (3) the definition of three distinct crustal domains in the basin, from the thinned continental crust to oceanic crust in the central part of the basin, through a transitional zone; and (4) the probable igneous composition of the PMR. Thus, this study gives a better understanding about the formation of the Porcupine Basin through the observation of the asymmetrical crustal thinning, the characterisation of the nature of the different crustal domains, the study of the amounts of serpentinization in the uppermost mantle and the observation of magmatism.

Opening of the Porcupine Basin offshore western Ireland: numerical and analogue models

Louise Watremez ${ }^{1}$, Bruno C. Vendeville ${ }^{1}$, Tom Detollenaere ${ }^{1}$, Laetitia Le PourhieT ${ }^{2}$, AND CÉDric BuLOIS $^{3}$

1. Université de Lille, CNRS, Université Littoral Côte d'Opale, UMR 8187, LOG, Laboratoire d'Océanologie et de Géosciences, Lille, France 9

2. Sorbonne Université, CNRS, Institut des Sciences de la Terre de Paris, ISTeP, Paris 6 CNRS, France 3. Laboratoire de Géologie, Ecole Normale Supérieure de Paris, 24 Rue Lhomond, 75231 Paris CEDEX 5, France

The Porcupine Basin is a narrow V-shaped abandoned rift located offshore Western Ireland. New seismic refraction models image the crustal structures through the basin, and the probable presence of oceanic crust in the central part of the southern basin. Interpretation of seismic reflection data near the northern end of the rift (1) allows the definition of morpho-tectonic structures with higher resolution and (2) highlights the propagation of the rift toward the north. These observations give a better understanding of the history of the rifting and the role of the far-field forces that led to its formation.

The aim of this study is to understand the factors controlling the propagation of the rifting, and we will investigate how a continental rift starts, propagates and even forms some oceanic crust before finally failing. Thus, we will compare the available geological and geophysical observations with preliminary results of analogue and 3D numerical simulations of the rift propagation.

\section{Re-stitching the Newfoundland-Ireland conjugate margins back together with geophysical megatransects and plate reconstructions}

Kim J. Welford, Alexander L. Peace, Heide

MacMahon, Larry Sandoval, and Pei Yang

Department of Earth Sciences, Memorial University of Newfoundland, St. John's, Newfoundland and Labrador A1B 3X5, Canada

The deepwater Orphan Basin and adjacent Flemish Cap continental ribbon, offshore Newfoundland and Labrador, acquired their unique spatial configuration during the formation of the modern North Atlantic Ocean. On the conjugate Irish margin, the Porcupine and Rockall basins lie adjacent to similar continental ribbons such as the Goban Spur and Porcupine Bank, which developed simultaneously with the aforementioned Newfoundland features, and in response to similar tectonic processes. Despite their spatial similarities and cotemporaneous development, fundamental differences exist between the two conjugate margins in terms of the distribution and nature of petroleum systems, and the degree, style, and localization of crustal thinning and mantle serpentinization.

To better characterize the similarities and differences across the conjugate pair, we are endeavouring to construct geophysical crustal-scale megatransects that reconstruct the margins back together, while remaining true to spatial constraints from recent plate reconstructions. Our main targets of interest are the West Orphan, East Orphan, Rockall, and Porcupine basins, along with the Flemish Cap and Goban Spur. The megatransects are constructed from both seismic reflection data and gravity modelling/ inversion results, providing regional views of how the basinal and crustal structures vary both across and along strike of each margin. The seismic megatransects in particular allow for margin-to-margin reconstructed basin models to be restored back in time to their prerift state and for the evolutionary link between the conjugate basins to be tested. These types of studies are crucial for developing our fundamental understanding of basin evolution on rifted margins, particularly those with extreme crustal thinning and orphaned continental ribbons. The results are also directly relevant to petroleum exploration as they provide the regional full-crustal context. 


\section{Understanding the characteristics of hyperextended margins to model and predict new hydrocarbon plays in Atlantic deepwater provinces}

\section{Richard C. WhitTAKeR \\ GeoArctic Ltd., 3300, 205-5th Avenue SW, Calgary, Alberta T2P 2V7, Canada}

Over the past decade, hyperextension is increasingly recognized as a common extensional process on continental margins worldwide, although the complex history of these margins can prove to be problematic for explorationists. Extreme crustal stretching and thinning results in a corresponding and often overlooked high rate of thermal subsidence that creates accommodation space into which sediments are deposited. This requires a re-evaluation of hyperextended margins in terms of consequences for thermal subsidence, basin connectivity, and flexural uplift.

We have evaluated in detail the new hydrocarbon discoveries on the Newfoundland margin and southwest Barents Shelf using a palinspastic deformable plate reconstruction. This has provided insights into the characteristics of Atlantic deepwater provinces in general. We show that many of these provinces share characteristic structural features associated with hyperextension such as deepwater basins and starved basins on the distal margin, perched basins, uplifted basin margins and the development of submarine escarpments, highly rotated fault blocks, and localised shear zones. During extension, the amount of stretching of the continental crust generally increases from the hinge line, which marks the transition from undeformed to deformed crust, to the distal parts of the margin where maximum stretching occurs. This causes a corresponding change in facies and palaeogeography across the margin, variations in subsidence and basin margin uplift, and has consequences for heat flow and hydrocarbon maturity.

Our palinspastic deformable plate model extends from the Central Atlantic to the Arctic and includes exciting new areas such as Guyana/Suriname-Mauritania/Senegal conjugate margins where significant discoveries have recently been made. The application of new modelling methods in these areas reveals a complex tectonic evolution and allows comparisons to be made to regions of interest such as Nova Scotia and the US Eastern Seaboard, Morocco, the Porcupine and Orphan Basins, and Iberia.

The characteristics of hyperextended margins and adjacent structural features are not yet fully recognized, but when the structural processes at hyperextended margins are well understood, they can show us the way to potential new petroleum plays.

\section{MLA-SEM analysis of well cuttings from Newfoundland and Labrador offshore basins}

\section{H. C. Wilton ${ }^{1}$, M. Feely², A. Costanzo2, J. Hunt², AND D. NORRIS ${ }^{3}$}

\section{Department of Earth Sciences, Memorial University of Newfoundland, St. John's, Newfoundland and Labrador} A1B 3X5 Canada 9

2. Earth and Ocean Sciences, School of Natural Sciences, National University of Ireland, University Road, Galway LL32 8FA, Ireland g

3. Nalcor Energy Limited, 500 Columbus Drive, St. John's, Newfoundland and Labrador A1B 0C9, Canada

Mineral Liberation Analysis-Scanning Electron Microscope (MLA-SEM) of well cuttings were undertaken to ascertain whether quantifiable data on their mineralogy and physical characteristics could provide insight into potential stratigraphic breaks within the sample set analysed. These insights can be utilized to evaluate stratigraphic relationships within the wells analysed and potentially establish a framework to build a mineralogical database for Newfoundland and Labrador's offshore region. A total of 236 well cuttings samples were analyzed with 176 from seven legacy wells offshore Labrador and 60 samples from three offshore Newfoundland wells. Sandstone lithologies were sampled preferentially, due to the multi-phase analysis with a National University of Ireland, Galway (NUIG) fluid inclusions study.

The MLA-SEM data defined mineralogy, sorting, and angularity of grains within each sample. Mineralogical Associations (MAs) were established for sample subgroups within each well to define intervals with discernible mineralogical attributes that might provide inter-well stratigraphic insights. These MAs can be further assessed for their physical characteristics such as grain size, sorting, and angularity in defining stratigraphic packages within each well. Also mapped were diagenetic cement types and amounts that provide insight into the dynamic fluid system affecting the areas from where the samples were taken. Results from this study, paired with fluid inclusion analysis completed by NUIG, suggest that hydrocarbon-bearing fluid inclusion samples were derived from well-sorted, mature intervals.

Further advancement of the MLA-SEM cuttings analysis technique could offer stratigraphic insights within frontier exploration regions of Newfoundland and Labrador's offshore. Future analysis may be incorporated with provenance studies to provide insight into sediment input terranes, as well as establish distinct mineralogical differences within stratigraphically complex regions. Further work on broader stratigraphic intervals may lead to mineralogically defined stratigraphic successions that would be of great support to previous work completed within this frontier region. 


\section{The effects of salt on Lower Jurassic source rock maturation on the Scotian Margin}

Juan C. Wong, Xin Yue Hu, Ricardo L. Silva, and Grant D. WACH

Basin and Reservoir Lab, Department of Earth Sciences, Dalhousie University, Life Sciences Centre, Halifax, Nova Scotia B3H 4R2, Canada

Organic-rich intervals havebeen identified in the Mesozoic conjugate margins of the North and Central Atlantic. The depositional environments and paleogeography of the conjugate Western European and African domains contain a proven Lower Jurassic source rock succession. This suggests similar intervals may exist in the conjugate offshore Scotian Margin $\left(280000 \mathrm{~km}^{2}\right)$ though these have not been drilled. If present, there is an uncertainty of their source rock characteristics (quantity, quality, and maturity).

Salt basins are part of the evolution of rifted margins, as seen in the Gulf of Mexico, West Africa, the Persian Gulf, the North Sea, etc. which are known prolific petroleum systems basins. In the Scotian Basin, Lower Jurassic intervals overlie the evaporites of the latest Triassic (Rhaetian) Argo Formation that have mobilized since deposition. These salt structures produce thermal irregularities that would affect maturity of these potential source rocks.

To test the postulated Lower Jurassic source interval on the Scotian Margin for maturation and source rock potential, PetroMod ${ }^{\text {mu }}$ by Schlumberger was used to build 2D models by using dip lines of the ION NovaSPAN ${ }^{\mathrm{Tw}}$ geophysical dataset. These models display a variety of salt structures observed across the Scotian Basin. The problems of modelling salt are not well addressed in petroleum system models, and their complexity is often ignored or over simplified. These salt structures are a concern when using petroleum systems modeling as it may affect the maturity and quality of possible Lower Jurassic rocks. We can see the thermal effects that the salt has on each model that was tested with the models demonstrating the effect salt has in the Scotian Basin.

The results show that source rock quality and maturity in the Scotian Basin are affected by the salt mobilization, which affects the transformation ratio (organic matter to hydrocarbons) of the Lower Jurassic interval. These resulting compilations of models suggest a potential Lower Jurassic source rock in the Scotian Basin existing within the oil maturity window in the southwest, transitioning to a gas maturity window in the northeast. Determining the maturity of the source rocks reduces the risks related with ongoing and future petroleum exploration offshore Nova Scotia.

\section{The impact of the Oligocene sea level lowstand on petroleum systems worldwide}

\section{Marcos Zentilli and Grant D. Wach}

Basin and Reservoir Lab, Department of Earth Sciences, Dalhousie University, Halifax, Nova Scotia B3H 4R2, Canada

The Eocene (ca. $55.5 \mathrm{M}$ a) saw a thermal maximum with global average temperatures $8^{\circ} \mathrm{C}$ warmer than today followed by a remarkable transition to the Oligocene (ca. 35-33 Ma). These are the most profound oceanographic and climatic changes recorded in the past $50 \mathrm{Ma}$ with global cooling of ca. $30^{\circ} \mathrm{C}$ and eustatic sea level lowering from $55 \mathrm{~m}$ to $155 \mathrm{~m}$. Accompanying these phenomena was a global increase in $\delta^{18} \mathrm{O}$ of $1.0 \% 0-1.5 \%$ throughout the Atlantic, Pacific, Indian, and Southern oceans and dramatic drop in the calcite compensation depth. Many scientists attribute this change to the formation of polar ice sheets but there is controversy regarding the causal mechanisms.

The world's sedimentary basins record major unconformities and sequence boundaries associated with this transition. Some ascribe part of the drop in sea level to global spreading-rate changes and suggest large areas of the continental shelves were exposed subaerially exposed during tectono-eustatic lowstands triggering slope failure and submarine erosion. On the west coast of equatorial Africa, erosion of up to $500 \mathrm{~m}$ occurred with deep canyon incision and turbidite deposition on the slope. Some of the erosional processes are ascribed to oceanic bottom currents and renewed movement of polar waters by reorganization of ocean circulation, following the opening of the Drake Passage and the isolation of Antarctica.

We examine the Eocene-Oligocene transition in various basins worldwide and the impact on their petroleum systems and ask: (1) Did the Eocene thermal maximum and sea level highstand lead to generation of potential source rocks? (2) Did regressive sequences, related to the ensuing cooling and drop in eustatic sea level, lead to enhanced reservoir distribution and positive or negative effects on petroleum accumulations? (3) Could the Eocene-Oligocene transition be related to the post-Eocene cooling recorded by apatite fission track (AFT) thermochronology in the Scotian Basin?

AFT studies show the rocks in many Scotian Shelf wells attained peak temperature between 60 and $40 \mathrm{Ma}$ and subsequently cooled 10 to $25^{\circ} \mathrm{C}$. Explanations include significant post-Eocene erosion due to eustatic lowstand, regional tectonics, higher mean annual surface paleotemperatures, local circulation of hot fluids, and effects of salt. Is erosion via canyons or longshore currents sufficient to explain the thermal data? Could rapid unloading have led to overpressure and faulting in already pressurized and confined reservoirs on the margin? We will investigate the causes and impacts in this paper. 